Euskal ikerketen aldizkaria | Revue d'études basques |

Revista de estudios vascos | Basque studies review

Numéro Spécial 1 | 1999

Les lettres basques au temps d'Axular (1600-1650)

\title{
Joannes Etcheberri ziburukoa : noelac eta testu kritika
}

Isaac Atutxa

\section{(2)enEdition}

\section{Journals}

Édition électronique

URL : http://journals.openedition.org/lapurdum/1626

DOI : 10.4000/lapurdum.1626

ISSN : 1965-0655

Éditeur

IKER

Édition imprimée

Date de publication : 1 octobre 1999

Pagination : 233-312

ISBN : 2-84127-157-9

ISSN : 1273-3830

Référence électronique

Isaac Atutxa, « Joannes Etcheberri ziburukoa : noelac eta testu kritika », Lapurdum [Linean], Numéro Spécial 1 | 1999, Sarean emana----an 01 juin 2010, kontsultatu 30 janvier 2020. URL : http:// journals.openedition.org/lapurdum/1626; DOI : 10.4000/lapurdum.1626 


\section{Isaak ATUTXA}

\section{JOANNES ETCHEBERRI ZIBURUKOA : NOELAC ETA TESTU KRITIKA}

\section{Atarikoak}

Jaraian aurkezten dugun lantxo hau luze eta zabalago doan beste baten laburpen edo atal gisa hartu behar da. Haren izenburua Joannes Etcheberri Ziburukoa: Obraren berrirakurpen bibliografikoa eta testu kririka dugu eta, bistan denez, gai berberaren aurrean gaude; han, Etxeberriren obra osoaren azterketa garatzen da, hemen, labur bada ere, bere obra batena: Noelac liburuarena hain zuzen.

Lanaren izenburuak berak adierazten duenez, bibliografia eta testukritika zereginak ditugu. Bibliografiari gagozkiola, abiapuntu joan den mendeko hondarretarantz agertu zen Julien Vinsonen Essai d'une bibliographie de la langue basque dugu, lan hau baita, inolako zalantzarik gabe, euskal literaturaren ikuspegi kronologikorik zehatzena eta zabalena aurkeztuko duena. Testu kritikari đagokionez,' argi dago edizio kritikoaren prozesuan bi alde aski desberdinak ditugula: recensio-a eta constitutio textus-a. Recensio hau, era berean, a) fontes criticae, b) collatio codicum, c) aldaeren examinatio eta selectio-a eta d) constitutio stemmatis codicum-a posible denetan. Lanak, metodologia honi jarraiki, recensioaren zeregin hauei azpiatal bana eskaintzen die.

Honela, lortu nahi ditugun helburuak jarraikoak dira:

1) Fontes criticae, collatio codicum eta examinatio eta selectioez baliatuz, Noelac liburu honen lekukotasun berri bat aurkitu dugula erakutsi, inon katalogatu gabeko lekukotasuna.

2) Noelac liburu honen lekukotasun guztien filiazioa eta constiturio stemmatis codicumari esker, Joannes Etcheberriren obrari buruz egin diren sailkapen kronologikoek (aipatu Vinsonena bereziki) huts larriak dituztela erakutsi, guzti hau lekukotasun guztien biluzketa eta konparaketak eragindako aldaeren ikerketa zehatz eta sistematiko ezak eragina.

\section{Nor dugu Joannes Etcheberri?}

Badakigu XVI. mendearen hondarretarantz jaio zela. Non? Ziburun. Eliçra erabiltceco liburua-n «dotor teologo ziburutarrak» sinatzun du. I difitte jaunaren artikulu but aipatu behar dugu, bestalde, jaiotza data ezagutu uahi izatekotan: Oihenarten I.' 'urk' poetique basque (Un inédit d'Arnaud d'Oyhénarl) hain zuzen ere (1967: 123-128).

Testu kritikari buruzko kontu guzti hauek gure hizkuntzan azaltzen ditu Joseba Lakarrak bere "Testukritikaz: 1. Stemmarantz" artikuluan (Lakarra: 1988b).

2 Oraintsu, Patrizio Urkizuk itzuli du Oihenarten L'arte hau. Ikus 1994, "Oihenarten Atsoritzak eld Poetika berrirakurtiz". Iker 8. Euskaltzaindia. Bilbo. 295-328. or 
Dictionnairc des L'ttres Françaises (XVI ${ }^{e}$ siécle, Arthème Fayard, 1951), Nouvelle Biographie Gínérale (Dr Ilelfer, Fermin Didot, 1856), Biographie Universelle (Michaud. 1815), hiru liburuotan edan eta hiruetan datu berdintsuak aurkitzen ditu I.afittek: XVI. mendearen erdialderantz euskal idazle bat i/an umen zela, Etcheverri (Juan edo Jean) deitua, Nafarroako Tafalan jaioa, apaiza, I cologian doktore.

Lafitteren ustez Etcheverri honck gure Ektheberri hau izan beharko luke. ${ }^{3} \%$ ir dakigu Joanes Etcheberriz?, galdetzen dio bere buruari.

3) Ziburum jajoa dela eta ez Tafallan.

2) Bere hiru anaien garaj berean hartu zuela sendotza Bertrand Etxauzengandik. Hauek honela, zera dio Lafittek: lau anaick sendotza elkarrekin hartzeko beharrezkoa zen parrokian denbora luzaz sendotzarik egon ez izana. Eta hau honela izan zen Mauri jaunaren ondoren Baionako apezpikutza hutsik izan baitzen (1593.etik 1598.era). Etxauz apezpikutzara heldu eta jarraian hasi baldin bazen bost urte horietan egin gabekoak betetzen, suposa liteke Baiona eta inguruetan (Ziburu barne) heltzeaz batera izango zirela, besteak beste, sendotzak, 1598 edo 1599 .ean. Are, sendotza 18 bat urterekin hartzen zuc11 garai hartako gazteriak. Gure kasuan, bada, Joanes Etxeberrik 1580-1586 urteen art(:ail beharko luke jaioa izarn.

3) Teologian doktore zela eta izen handiko gizona zela. Bere adiskideen laudorioak ikustea besterik ez dago honeliaz jabetzeko.

4) Ziburuko parrokiari buruzko datuek ${ }^{4}$ zera erakusten dute, 1629. urtean Martin

\footnotetext{
"Ciure ustez, datuok ez datoz bat jarraian azalduko dituenekin eta beste Etxeberri batez pentsatu beharko genuke. Patri Urkizu, garai hartako beste Etxeberri batez mintzo da. 1989 an bere doktore tesia argitaratzen da Mundaizen Pierre d'Urteren hizregia izenburupean. Liburu honen 33. orrialdean, "Protestantak Euskalerrian XVI-XVII. mendeetan" azpiatalean, honela dio: "Baina zer dakigu pertsonai guztiotaz? Hona hemen aurkitu dudana kronologikoki emana. Jean ETXEBERRI, detchevery, chevery, La Rive, edo euskaldun ttipia (Le petit basque) deitua Donibane Lohizunen jaioa liburu saltzaile zen, edo honela aurkezten zuen bederen bere burua 1552. urte inguruan Figeac-en.». Erreforma predikatzen ibili zen eta "hamar urtez, 1552-tik 1563-ra Quercy eta Revergue eskualdetako erreformaren zabaltzailerik sutsuenetarikoa izan zen.Genèven urte batez teologia ikasketak egin ondoren, Euskalertian ikusiko dugu Basanafarroan, Donapaleun, hain zuzen». 1578. urtean hil zen Luxeko gazteluan. Aurrerago honela dio Urkizuk (35. or.): «Jean Etxeberri agertzen zaigu ere biztanleen liburu aipatuan honela '/undy 8 may 1559 . Jehan dechebérry, escollier, natifz du fieu de S. Jehan de Lux près Bayonne' 's. Liburu aipatua P.F. Geisendorf-en Livre des habitants de Genève, T. I. 1549-1560, Genève 957,202 . or da.

P. Urkizu bera 1992ko beste artikulu batean, "Pierre D'Urteren hiztegia" AS:U Gehigarriak XV. 231242. or., kontu berberera itzultzen da.

-Gure ustez, kasu honetan Pierre Lafitte jaunak Haristoiren St. Jean de Luz el Ciboure. Souvenirs historiques et révolucionnaires avec quelque pages sur le Pays Basque liburua izan du iturri datuok emateko. Izan ere. honela dio Haristoik aipatu liburuan (1895: 80-81):
}

«Curés connus de Ciboure.., 1629.. Martin Gastambide; - de... à 1638, Jean d'Etcheverry ou Etcheverri, enfant de la paroisse, docteur en théologie, d'abord vicaire, puis curé. [...] 
Gastambide zela, oraindik, parroku; baita 1638.ean Jean Haristeguy dela Jean Etcheverry edo Etcheverriren oinordeko izendatua. Baina ez dakigu zein urtetan hartu zuen Etxeberrik Gastambideren tokia.

Lafitteren datuon arabera, bada, nahiko zehazki koka genezake Etxeberriren jaiotzaren data.

Etcheberrik berak ere azaltzen du bere bizitzari buruzko daturen bat Eliçara erabiliceco liburuan (1666: 2 ):

"Bereciqui ni naţ̧aitçu / Ceren eta çureaz, / Confirmatua içaiu / Bainaiz elcu emeaz.

Nerori anaia laurgarren / Ciburuco templuan. / Ceñetaric bici bainaiz / Bigarrena munduan."

Oihenar, Pouvreauri bidalitako —azken honen hiztegirako zenbait hitz. dela eta1661 .eko maiatzaren 30eko gutunean, «Feu Monsier d'Etcheberry»-z mintzo da.

Lafitte jaunak 1638.ean hil zela dio (1967: 13-14). Nik ez dakit nondik suposatzen duen data hau. 1638.ean. Haristegi da Etcheberri Ziburukoaren oinordeko izendatua. Etxeberri hil egin zelako?

P. Altunak (1981: 8) Paben ikasi zuela dio, jesuiten jkastetxean, Oihenartek bezalaxe. Egin behar izaten zituzten gutxi gorabeherako ikasketak Humanitateak eta gero gainerako ikasketak (Filosofia, Teologia, Zuzenbidea...) zirela dio. Eta litcheberri Teologia ikasi ezezik dotore izatera iritsi ere egin zen. Ez dugu bere bizitzari buruzko beste datu zehatzik lortu.

\section{Etcheberriren obra}

\subsection{Lan argitaratuak}

Hiru dira Joannes Etcheberriren lan argitaratuak; inprimatuak; ezagunak eta eskuragarri ditugunak behintzat.

\subsubsection{Manual devotionezcoa}

Hau da gurera heldu den Etchebertiren lehen liburu inprimatua. Lehen edizioak 1627.ean ikusi zuen argia, Bordelen Gilen Millangesenean. ${ }^{5}$ Hona Vinsonen Essai...n aurki

1638-1656. Jean de Haristeguy, entant et vicaire de la paroisse. ...."

${ }^{5}$ Inpresoreei dagokienez, derragun Manual devotionezcoaren bi edizio desberdinak Bordelen inprimatuak izan zirela. Ernesto Labadieren L'imprimerie bordelaise et les livres basques lana (1913) jarraituko dugu Bordeleko inprimatzaileoi buruzko zertzelada labur batzu emateko.

Simon Milangesek moldiztegi haundi eta garrantzitsu bat kokatzen du Bordelen 1572. urteaz geroztik. 
genezakeen aipamena:

"I4a.-MANVAL | DEVOTIONEZCOA, | EDO EZPEREN OREN | JRO ESCVETAN ERABILLT-- | çeco liburutchoa. | Efcarazco verfiu tan eguiña, efa gussia I bi partelan bereçia. I Lehenean iracaften direla. Guirintiño I Commun batec, iaquiñ behar diluen I Gauça guehienac: berçean, errateco I Lituquen. halaber othoinz guehienac.[...]

BORDELEN, I GVILLEN MILLANGES Erregueren I Imprimalçaillearenean. I - I M. DC. XXVII."

Argitarapen honen garaian, Bordele zen liburuak inprimatzeko lekurik hurbilena. Baionako lehen moldiztegia François Bourdot-ena da, 1642.ekoa. Eta Paben Desbarats sendia 1655.az geroztik baino ez da hasten inprimatze lanetan.

Lehen argitarapen hau in-8 itxurakoa da (16 orrialde pleguko), guztira 346 orrialde idatzi dituela. Bere neurtiak honakook dira: $101 \mathrm{~mm} \times 167$. Testuak berak $82 \mathrm{~mm} 5 \times 149,5$ (izenburu eta zeinadurak barne).

Bigarten edizioa 1669. urtekoa da eta hona Vinsonen aipamen bibliografikoa:

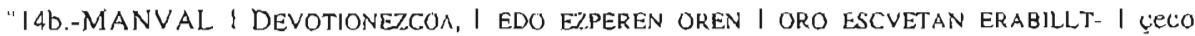
liburutchoa. I Efcarazco verfiufan eguiña, eta guztia I bi parretan bereçia I Lehenean iracaften direla, Guirifiño I Commun batec, iaquiñ behar diluen I Gauça guehienac: berçean, errateco I Lituquen. halaber othoitz guehienac. [...]

BORDELEN, I I. MONGGIRON MILLANGES Erregueren! Imprimaţaillearenean. I - M. DC. LXIX."
\end{abstract}

Litekeena da Iacobe Mongiron Milangesek lehenaz baliaturik egin izana berrargitarapen hau. In-8 itxurakoa hau ere, foleo erdiz eratua (8 orrialde pieguko).

Neurriak: testuak $88 \mathrm{~mm} 5 \times 152,5$, izenburu eta zeinadurak barne. Zeinadura sistema: 1627.eko argitarapenak A p. 1, B p. 17, C p. 33, e.a., K p. 137 ra arte; bigarren liburuak: A p. 1, B p. 17, e.a., O 208. orrialdean. 1669.eko argitarapenak: A p. 1, B p. 9, C p. 17, D p. 25, e.a., S p. 137-ra arte; bigarren liburuan: A p. 1, B p. 9, e.a., eta Cc p. 207.

Vinsonen aurretik, eta Etcheberriren beraren garaikideez landa, Jusef Egiategi ziburutarra dugu liburu honen berri dakarren lehena. ${ }^{6}$ Honen ondotik. Aita Larramendi,

baina 1623.era arte ez da moldiztegi honetan euskeraz idatziriko libururik aterako. Urte honetan bertan hil efa Jacques bere seme zaharrenari utziko dio bere moldizlegia. Aipatu lehen euskal liburua Etienne Materreren Doctrina Christiana-ren bigarren argitarapena da.

Milangesdarren bigarren euskal argitarapena gure Joanes Etxeberriren Mamual devolionezcoa da. 1 627.ean. Dakigunez, liburu honek Gilen Milanges inprimatzailearen izena darama. Gilen hau Jacquesen ondotik etorri zen, 1625.ean, eta Gilen honen oinordeko Mongiron Milanges izango dugu, bere loba, 1650.ean Mongiron Milanges da, izan ere, Manual-aren bigarten argitarapena plazaratuko duena 1669 .ean.

$\epsilon$ Bere Lehen liburia edo filusofo huskaldunaren ekhieia liburuan (1785. urtean argitaratua. Guk darabilgun argitarapena Txomin Peillenek prestatu eta Euskaltzaindiak 1983.ean argitaratua da. Orrialde aipamenak, beraz, edizio honi dagozkio.) Honela dio Egiategik 22. orrialdean: «Berze libujrü bat tritia diana Noetak ta berze Espiritual berriak, Baionan moldizkitaria, 1630. urthian, Joanes Etxeberri theologian dotoraren obra; ber ezkiribazaliak egin du ere berze libüru bat, Hüskararen adrezzaz, mintzo dena». Txomin Pesllenek ohar 


\section{Pierquin de Gembloux belgiar midikua ${ }^{8}$ eta Francisque Michel. ${ }^{9}$ Guzti hauen lana esozoa}

bat jarri du azken baiztapen honen segidan: «Hüskararen adretzaz ez du Etxeberri reologoak idatzi, baina Etxeberri medikuak, Larramendik, azken horren eskuidazkia eskuen artean eduki baitzuen» dioena.

'Bere Arte (1984: 374) eta Diccionario Trilingüue liburuetan (1853: xxxi), bietan dugu Etxeberriren lehen liburu honen berri. Ez du jartzen, ordea, zein argitarapenez minizo den.

"Bere Histoirc Litteraire liburuan (1858a: 7 gehigarrietan) Manual-aren berri izango dugu. Harritu egin gaitu aipatzen duen kontu batek. 1627. eko argitarapenaz mintzo dela, lehen atala in-f. itxurakoa dela dioen bitartean, bigarrena in-8-kotzat du. Ez ote ziren bi atalak batean argitaratu? Gure ustez, Pierquin de Gembloux oker dabil eta bi aleak dira itxura berekoak.

Bere Bibliographie basque liburuan (18586 7-8) disugun datuak bat datoz aipaiu dugun Histoireekoekin. Baionako Euskal Museoan lortu ahal izan ditugu Pierquin de Gembloux-en bi liburuok. Leiena, 1841. urtekoaren berrargitarapen bat da; oso ongi gorde da urteetan zehar eta ez du orririk falta eta denak daude bere osotasunean. Bigarren liburua, aldiz, separata bat da. Azalak falta ditu eta norbaitek beranduago, kartulinaz berregin ditu. Aurteko azalean, erako aldean, eskuz idatziriko titulua eta gainontzekoak ageri dira; itzuliko aldean, beste eskuz idatziriko lerro hauek ditugu:

"La brochure donnée au Musée basque est une avec pagination spéciale, de l'ouvrage suivant: Histoire littėraire, // philologique // et // bibliographique // des Patois // el de l'utilite de leur étude // par // Pierquin de Gembloux

Nouvelle édition // suivi de la Bibliographie générale des phonopolismes basques./

Paris // Auguste Aubry, libraire-éditeur // rue Dauppine 16// 1858.

[in-8, 339 pages, imprimé á Bourges, chez. P. A. Manceron]

Pierquin de Gembloux, né en Belgique, après avoir fait ses études de médicine en France. fut medecin d'un hôpital à Montpellier. puis il entra dans l'Université ê devint inspecteur d'Académie à Macon, puis à Bourges.

7.JII 1933

Polygraphe abondan il a écrit pour beaucoup de ........, livres et articles (médecine, archeologie, histoire, liguistique).

\footnotetext{
Honela dio Proverbes basques d'Oihenart-en ( $1847: \mathrm{x}$ )):
}

VII. Manual devocionezcoa. edo ezperen, oren oro escuetan erabilltçeco liburutchou. Escarazco versutan eguiña, eta guztia bi partetan bereçia... Bordelen, Guillen Millanges, Erregueren imprimatçaillearenean. M.DC.XXVII. (Manuel de dévotion, ou le petit vade-mecum de tout le monde, fait en vers basques et divisé en deux parties... Bordeaux, Guillaume Millanges, imprimeur du roi, 1627.) In- $8^{2}$ de 138 pages, signées A-K. précédées d'un feuillet contenant le tritre ci-dessus, et suivies d'un feuillet blanc.

La Jicencia vicarii generalis qui se trouve sur le recto du feuillet A. porte: «...manualis, Cantabrico carmine a loanne Etxheberri Doctore theologo compositi...s cette licentia est signée M. D'OIHARARD, vicarius generalis.

La première partie de cet ouvrage renferme. en vers de huit syllabes, les principaux mystères de la vie de Jésus-Christ; la seconde partie, également consacrée à des sujets de piété, est en grand vers de quatorze syllabes. Elle est intitulée: Bigarren luburüa guiristinoac erran behar lituzqueen othoitcez... Bordelen, Guillen Millanges Erregueren Imp̣rimatçaillearenan. M.DC.XXVII. (Deuxième livre des prières que le chrérien devrait lire... A Bourdeaux, chez Guillaume Millanges, imprimeur du roi, 1627.) De 208 pages, le titre compris; puis viennent quatre feuillets contenant la table des deux parties. La seconde porte les signatures A$\mathrm{N}$, et la table la signature $\mathrm{O}$.

Oker dago Michel jauna lehen ataleko bertsoak zortziko eta bigarrenekoak hamalau silabatakoak direla baieztatzen duenean, 15 silabatakoak baitira liburu osokoak. 
eta zehaztasun gutxikoa da. Vinsonen ondorengoak dira Genaro de Sorarrain ${ }^{10}$ eta Louis Desgravesen" lanak.

Hordago Publikapenak elxea 1669.eko edizio honetaz baliatu zen argitarapen xerokopiatu bat egiteko. ${ }^{12}$

Patxi Altunak, azkenik, Marual devotionezcog honen lehen liburmitn edizio kritikoa paratu zuen 1981 .ean, Hordagoren argitarapenaz baliatuz.

Ezin izan zuen Altuna jaunak lehen argitarapeneko alerik aurkitu, batez ere 1669.ekoan 3.438. bertsoaren inguruan berlso balzuk falta zitezkeen, berak uste buzala, edo ez jakiteko.

Patxi Altunaren uste honek bultzatua bibliografia irakurtzen hasi ginen. Vinson-en Essai... liburuan (1891-8: 65) 1627.eko ale bat Pariseko Bibliothèque Nationale-n zegoela irakurri ahal izan genuen eta, aipatu bezala, Deustuko Unibertsitateko Eusko Ikaskuntzako Karmele Santamariari esker lortu genuen lehen argitarapen honen mikrofilmaren fotokopia.

Bi argitarapenen arteko konparaketak zera erakutsi digu. Patxi Altunak aipatzen dituen bertso hauetan («Egoquien Aingueru beguirailleei» izenburua duten 3.427-3.442 bitartekoak) 1669.eko argitarapena lerroz lerro dagokiola 1627.ekoari. Ez du horrek esan nahi, ordea, bertso batzuk ezin falta daitezkeenik. Are, 1669.eko argitarapena kaleratzeko aurrekoaz baliatu izan balitz Mongiron Millanges (eta hau geuk proposatutako hipotesi bat

Michelen Le Pays basque liburuan ere (1857: 487-8) Manual-aren lehen argitarapenaren aipamen berbera dugu. Bietan dio lehen argitarapen honen berria Aita Larramendirenetik jaso duela, baina azken hau izenburuen aipamenetan gelditzen da gehienetan.

Les proverbes basques-en cre (1847: xivj) bigarren argitarapenaren berri dugu. Bordelen. J. Mongiron Millangesenean inprimatua, in 8 r itxurakoa dela diosku.

10 Bere Caráloge de obras euskaras liburuan ere (1898: 46-47) aurkitu ahal izango dugu Etxeberriren liburu honen aipamenik. Vinson jauna jarraitzen duelako susmoa dugu, ordea, eta bildu dituen datu guztiak Essai...-n aurkitu dituela.

i] Louis Desgravesek, bere Les livres imprimés a Bordeaux au XVIF siécle liburuan, Manual devotionezcoa-ren bi argitarapenen berri dakar. 1627. urteko argitarapena bere liburuko 588. zenbakidunari dagokio (1971: 92), erakusten diguna aipamen bibliografikoa besterik ez dela. Vinsonen Essai...-n edan du eta ale bat Pariseko Bibliothèque National-en dagoela dio (D. 33.877). 1.346. zenbakia duen aipamenean aurkituko dugu 1669. eko argitarapenaren berri. Kasu honetan ere, Vinsonen Essai... -n edan du eta Bordeleko Herri Liburutegian ale ezoso bat dagoela esaten zaigu (PF. 16.185 Rés.).

12 «Euskal klasikoạk» bilduma argitaratzen hasi zen Hordago Publikapenak etxea 1978.ean, eta Joanes Etxeberriren Manuai devotionezcoa dugu bilduma honetako lehen liburua. Honako hau litzateko aipamen bibliografikaa:

HORDAGO PUBLIKAPENAK. 1978, Mamual devotionezcoa edo ezperen oren oro escuetan crrabilltçeco liburutchoa. Etxeberri Joannes, Editorial Lur, Donostia. 
besterik ez da) ez zegokeen bigarrenean lehenean ez dagoen bertsorik.

\subsubsection{Eliçara erabiliceco liburua}

Hau da Etcheberriren luirugarren lan inprimatua. Bigartena Noelac da eta jarraiko kapituluan izango dugu mintzagai.

Jusef Egiategi cta Aita Larramendik ez dute beren lanetan aipatzen (ezagutzen ez omen zutelako?). Badu, haatik, F. Michelek liburu honen berri bere Proverbes basquesen. ${ }^{13}$

\subsubsection{1636.eko argitarapena}

Vinsonen sailkapenaren arabera hiru argitarapen desberdin ezagutu izan ditu liburu honek mendeetan zehar. Hona hemen balizko lehen argitarapenaren aipamen bibliografikoa (1891-8: 76):

"17a.- Eliçara erabilceco liburua foannes Etcheberri Dotor Theologoac eguiña eta iaun Noble Bertrano de Etchaus Tursco Aphezpicu digneari dedicatua. Bordelen, Guillen Millanges Erregueren imprimatçaillea baithan 1636."

Vinsonek dioenez, aipamen hau M. Pierquin de Gembloux-ek egiten du bere Historie littéraire liburuan, baina berak zalantzatan jartzen du Pierquin honen lana «insuffisant, désordonné et inexact» delako.

Hau da, izan ere, Pierquin de Gembloux jaunaren aiparnena: «Etcheberti Joannes, Eliçara erabillceco liburna, etc, in-18, Bordelen Guillen Milanges Erzegueren, imprimatcaillea baith an 1636, p. 542.» (1958a: 264). Gehigarrictan ere aipamen berbera dugu. Eta bai, baliteke Pierquin-en lana «insuffisant, désordonné ct inexact» izatea: baina, dirudienez, begibistan izan du argitarapen hau. Bere neurria (in-18) cta bere orrialde kopurua (54.) ) er cmaten dizkigu. Eta c\%agutzen diren beste bi argitarapenak ez dato\% 1.11 bi datu hauekin. Baliteke, bestalde, Pierquin de Gembloux berak ere beste nonbaiten jaso izana datuok.

\subsubsection{1665.eko argitarapena}

Irakurri ahal izan dugun bibliografiak. lagundu beharrean, kasu honetan, nahastu

\footnotetext{
is Hona hemen bere aipamena:
}

"XVI. L'anné suivante (1666.a). parut à Pau un volumen in-24, sous le titre d'Eliçan erabilceco liburia (Livre qu'on doit porter dans l'eglise); nous ne le connaissons que par la citation fautive qu'en fait le Mithridates."

Aipamen honek argi erakusten du Etxebeni Ziburukoaren hirugarren liburu hau oso ezezaguna eta aurkitzen oso zaila izan dela. 
egin gaituela esan behar dugu. Beti bezala, J. Vinson hartu dugu abiapuntu eta bere Essai...$n$ irakurria da jarraian azaldu nahi duguna. Hau da Eliçara erabiltceco libuma-ren bigarren argitarapen honen lehen aipameria (1891-8: 77):

"17b.- ELICARA I ERABILTCECO I LIBVRVA. I IOANNES ETCHEBERRII Dotor Theologoac I eguiña. I Era iaun Nobie BERTRANO I DE ETCHAvs Turfce, I Archiphizpicu dignea-I ri dedicatua. I (fleuron) I BORDELEN, | 1. MONGIRON MILANGES, | Erregueren Imprimat- |çaillebaithan. 1665.

Pet. in- 8 - (Ixvj)-435 p; signatures: aux fts préliminaires de un à six pieds de loup: pus A p. I. B p. $16<17>$, C p. 25 , D p. 41 , E p. 49 , etc.

- Le texte mesure $86^{\mathrm{mm}}$ de hauteur sur 42 de justification.

Je connais trois exemplaires de cette édition, dont un complet. Un des deux autres est a la Bibliothèque municipale de Bayonne $\left(n^{9} 3822\right)$.

Coll.: p. (i-ij) titre, (iij-vi) dédicace, (vii) approbations de MM. Guillentenea et Axular (Sare, 16 mái 166 (sic), (viij-ix) vers latins â l'éloge de l'auteur signé d'Iharce, ( $x$-xiv) vers français, signés Casabielhe, (xv) vers basques signés J. Claverie, (xvi) vers: harc berac <hari> berari, (xvij-xviij) vers de Tristand de Aphezte, (xix) vers: harc berac <hari> berari, $(\mathrm{xx})$ division du livre, (xxij-xl) calendarioaz eta demboren contuaz "du calendrier et du compte du temps», ( $\mathrm{x}|\mathrm{j}-\mathrm{x}| \mathrm{v})$ tableaux de l'épacte, de la letre dominicale et des fêttes mobiles de 1665 a 1683 , (xivj-|xvj) calendrier; - p. 1$82 \angle 4>$, première partie (devoirs du chrétien), premier traité (prières quotidiennes, en vers); p. $82<5>$. 134, deuxième traité (doctrine chrétienne, en vers); p. 135-166, troisième traité (de la confession, en prose); p. 167-423, deuxième partie (heures, en vers; les psaumes de la pénitence sont aux p. 316 et suiv.; aux p. 368 à 423 est la dévotion à Marie); p. 425-435, table.

<Commencement des p. 81 Duçun orhoi, 1937. Hargatic, 273 Eta llraelen, 346 Bartholome, 403

3. Laurguitu.>"

$>$ artean jarri ditugu J. Vinsonen beraren zuzenketa eta gehiketak, hain zuzen ere bere Essai...-ren bigarten alean jarri dituenak (aip. lan.: 544). Zuzenketa eta gehiketon artean, honako aipamen berri hau jami du:

"17 b, c - ELICLARA, etC.

Edition conforme \&̀ la précédente, suf ce qui suit:

Pet. in-12-(1xvij) - 435 p.

P. (vij) approbations de P. de Archular. P. de Guillantena (22 de mai 166 (sic), (viij-ix) vers latins signés «1. Mharfius in Curia Baionenfï caufarum Patrunus», (x-xiv) vers français, signés: 1. D. Casabielhe, s' de Chabatenea, de Saint-Jean-de-Lux; (xv) vers basques signés: Iean Claveria, Apezac;.....(xvij-xviij) vers de Tristan de Aphezte, Apphesac;.... (xx-xxi) division du livre; (xxij-xxxix) Calendarioaz, etc.; (xl) blanc; (xlixliii) tableaux de 1665 à 1683: (xliv-|xvii) calendrier; (lxviij) blanc; - 1-82 première partie, premier traité, 83-135 deuxième raité; 135-166 troisième traité; 167-423 deuxième parlie (ps. de la pénitence aux p. $316-$ 344, la dévotion á Marie aux p. 368-423): $425-435$ table.

Le texte a une justification de $42^{\mathrm{mm}}$ sur 98 de hauteur (chiffres et signatures compris).

Erreurs de pagination: 117 pour 107,30 pour 130,178 pour 187,303 pour 203,149 pour 249,369 pour 359,374 pour 363 .

Commencement des p. 81 Duçun schoi, 192 7. Hargatic, 273 Eta liraelen, 346 Bartholome, 4033. Laurguitu.

Signatures: préliminaires: un ả six pieds de loup aux p. i, xvij. xxv, xlj; - A p. 5, B p. 21, C p. 29, D p. 45, etc., jusqu'à Mm (demi-feuille contenant les quatre derniers feuillets de la table).

Sur quatre exempl. de cet ouvrage et de cette édition que j'ai eus entre les mains, deux avaient à la p. 220 la réclame harran en petit texte: les deux autres avaient hartan en texte ordinaire. A part cela, les quatre volumes étaient identiques."

Kontua da Vinsonen beraren zuzenketa eta gehiketetan, hau da Essai. .ren bigarren 
alean (aip. lan. 544) aurreko aipamen berri hau dugula (17 b,c). Jarraian $17 \mathrm{c}$ aipatzen du. Honek 17a, 17b, 17 b.c eta $17 \mathrm{c}$ lekukotasunak eskuartean erabili dituela pentsarazten digu. Bestalde, doktore tesirako erabili dugun materialen artean, Baionako euskal museoan aurkitutako eskuizkribu bat dugu. Honen izenburuan "Comparación de las dos ediciones de 1665 de 'Eliçara erabiltceco liburua' de Joanes Etcheberi" dugu eta kontu guzti hauek sail egiten dute 1665.ean edizio bakarra edo gehiago izan ziren argitzea. Guk 1665.eko zortzi ale desberdin izan ditugu eskuartean eta guztiak datoz bat Vinsonen 17b,c aipamenarekin. ${ }^{\text {is }}$

\subsubsection{1666.eko argitarapena}

Hona, orain, hirugarren argitarapenaren Vinsonen aipamena:

"17 c.- ELIÇARA I Erabiltçeco I libvrua. I ioannes etcheberry I Dotor Theologoac I eguiña. I Era laıs" Noble BERTRAND I DE ETCHAVS Turfoo, I Archiphizpicu digncari I dedicatua. | Bigarren aldian Imprimaluá. I (fleuron) I PAVEN , I loannes Desbaratz. I Erregueren Imprimatçaillea I Baithan. I666."

Hau ere in-8 txikia erakoa da, (ij)-64-517-(xj) orrialdetakoa. Zeinadurak: aurretikoetan a p. (i), a ii p. 1, e p. 17, i p. 33, o p. 49; testuan A p. 1, B p. 17, C p. 33, D p. 49 , e.a. Neurriak: $50 \mathrm{~mm} 5 \times 96 \mathrm{~mm}$.

1666.eko argitarapen honek 1665.ekoak ez dakartzan bertso batzuk ditu, gnre ustez Bernardo Gazteluzarrenak direnak. ${ }^{\text {is }}$

\subsection{Lan argilaragabeak}

Bere mendeko bi idazleri esker (Oihenart eta Pouvreau) jakin ahat izan dugu Exxeberrik, argia ikusi zuten hiru liburuez landa, beste zenbait izkribu ere idatzi zuela.

Oihenartek, bere Arle-an (Lafitte, 1967: 38-39), Exxeberriren bertsogintzaren azterketa egiten du Manual-eko adibideak jarriz. Aurkitzen dizkion hutsuk direla eta, bere Noelac, Egumoroscoa eta Eliçara Erabilzecoa ez direla hobeak dio. Datu hauen arabera, bada, Etxeberri Ziburukoak Egunoroscoa izeneko best: obra bat ere idatzi omen zuen.

Aurrera jarraitzen du bertsogintzaren azaerketan eta zera dio, hitz lauz idatzi izan balu garaile aterako zela, inprimatutako obrez apartc. hcre senideartek.o gutunak, zenbait laguni idatziak, bere hiztegia eta bere aditz jokoek (Oihenartek haren eskuz idatziak ikusi zituenak) ongi erakusten baitute euskaraz izan zuen askitasuna.

P. Altunak Manualaren edizio kritikoan (1981:10) Egunoroscoa hori Manuala bera ez ote den galdetzen dio bere buruari, Etxeberrik titulu osotik «oren oro» aldatu eta «Egun

${ }^{14}$ Zehaztasun gehiagotarako ikus Atutxa 1999, Eliçara erabiltceco liburuari eskainitako kapituluan.

Ikus, hemen ere, Atutxa 1999, Eliçararen kapitulua. 
oro-scoa» izendaturik. Aita Akesolok zera diosku (1970: 6-7): "Oihenarten lan batean beste bat ere aipatzen da: Egunurozcoa. Beste xeetasunik ez digu entuten. Eta csan beutra dago orainarte ez dela orren aztarnarik azaldu, eta beste iñork e $<$ duela bere ezagutzerik eman. Liburu berria ote da, lengoez beste bat ote da, ala besteen zatien bat, edo besteen zatien bati eman ote dio Oihenartek izen ori? Gogoan ar dezagun Elizara erabiltzeko liburuak ere baduela zatí bat, Fgunorozko ol hoitz laburrak titulutzat daramana. Eta, gaiez, berdintsu da Manualaren bigarren zatia ere.

Au esanez, ez dugu ukatu naj libun ori izan denik. Eta iñoizkoren batean agertu baledi, ongi etoria izango litzateke euskal-literaturan. Bai orixe.».

Eliçara erabiltceco liburuaren 1665.eko edizioaren 435 orrialdeetan zehar hiru atal itgi desberdinduak aurki gunitzake: lehena "calendarioaz edo demboren contuaz tratatua» deritzona eta beste biez hau da liburuan bertan aurkituko dugun aipamena: «Liburu hunen parteac. Liburutcho hau bi partetan berezten da. Iaquiteco Guiriftinoaren equinbidean, eta orenetaco othoitcetan. Lehenbicico partean dire. EGUN OROZCO othoitz laburrac. Doctrina Chriftiana. Eta Cofeflatceco antcea.»

"Egun orozco» otoitz horiek 1-82 orrialdeetan zehar banatzen dira eta ez dakigu Oihenart atal honetaz ari zenentz egiten zuen aipamena egiten zuenean. Bi lirateke, gure ustez, ikerketa hipotetiko batean jarraitu beharko liratekeen bideak: argitaratu gabe eta, noski, galdua den Etxeberriren laugaren liburu batez ari zenekoa edo, bestela, Munual devotionezcoaren bigarren liburuari buruz ari zenekoa.

Ez zaigu, geroztik, beste inor mintzatu Oihenartek aipatzen dituen gainontzeko lan horietaz eta betiko galduak izan daitezkeeneko susmoa dugu.

\section{Noelac eta testu kritika}

\subsection{Tradizio moetak ${ }^{16}$}

\subsubsection{Zuzeneko tradizioa}

Hau da Etxeberri Ziburukoak idatzi eta gugana heldu den bigarren liburua eta bera $\mathrm{da}$, alde haundiz, bere liburuetarik argitarapen eta berrargitarapen gehien izan dituena, 10 guztira, antologietan eta argitaratu diren bertso sorta eta abarrez landa.

Oraingoan ere Jusef Egjategi dugu Jiburu honen bersi eskajntzen duen lehena. Jkusi dugunez, «Noelak eta berze Espiritual berriak» idazten du, «Baionan moldizkitatia, 1630. urthian».

Aita Lartamendi dugu berri eskaintzen digun bigarrena. Ionela dio bere

26 Joseba Lakarrak dioenez (1988b: 120) «testua gureganaino irits dakiguke a) zuzenean edo zeliarka. b) eskuizkribuz edo inprimaturik eta c) lekukotasun bakarrean edo gehiagocan». 
Diccionario-n $(1853: \mathrm{xxxi})^{17}$ :

4.0 Otro librito en dozavo impreso en Bayona año 1630, aunque con muchas erratas. Su autor Joanes de Echeberri, doctor teólogo. Contiene doscientas cincuenta páginas y está todo él en verso. Su titulo Noelac eta berce canta Espiritual berriac. El asunto es la vida de Cristo y sus principales misterios..

Aita Larramendik 1630.ekoa dela esanagatik, egunera arte ez da urte horretako argitarapenik aurkitu.

Pierquin de Gembloux jaunaren aipamena (1858a: 7 gehigarriak) hau da: (NNoelac etá berce canta espiritual berriac in-12, Bordeaux 1630, pp.250».

Aita Larramendi eta Pierquin-en datuak ikusita, argi dago kontu batean behintzat ez dabilela oker azken hau: 1630. urtean ez dagyo (gero ikusiko dugunez) inprimatzailerik Baionan. Ezin izan, bada, lehen argitarapen hau Baionan inprimatua.

F. Michelen Proverbes basques liburuko aipamena (1847: xl) Larramendirenetik jasoa da eta ezer gutxi du berririk. Le Pays basque-n (1857: 488), ordea, eskuartean argitarapen desberdin bat erabiltzeko aukera jzan duela dio, honako aipamen hau eginez:

"Noelac eta berce canta espiritual berriac. Jesus Christoren biciaren misterio principalen gañean. Eta sainduen ohoretan besta buruetacolz. Ioannes Etcheberri Doctor Theologoac cọniñac. Baionan, Maffre Bairan, bors Cantognetan, 1697, in-24, 240 pages."

Hemen dugu, bada. Larramendik aipaturikoaz gain, beste argitarapen berti bat.

Behin, L. L. Bonaparteren Eskuizkribuak-Argitaropenak liburua (1989) arakatzen geundela, hurengo bi aipamenok irakurtzeko aukera izan genuen:

352. UN PATRIOTE. Recueil des quelques Eclaircissemens Relatifs au paiss et peiple Basque. Par... Dedié a son Altesse Le Prince Napoleón. Bayonne le 24 Fevrier 1866.

Cuaderno, 41 hoj., $23,5 \mathrm{~cm}$.

Proc:: ADN m/s B-95.

MICROFILM 2 C 27

352 bis. (NOTA bibliográfica sobre Joanes Etcheberry).

2 hoj. $27 \mathrm{~cm}$.

Proc: : ADN m/s B-105.

MICROFILM 2 C 27

Euskaltzaindiako Azkue Bibliotekako Bonaparte Printzearen eskuizkribuen mikrofilmetan bilatu eta han aurkitu genuen, «UN PATRIOTE» honen 41 orrien ondoren, Joanes Etxeberri Ziburukoaren Noelac eta Eliçara erabiltceco liburua-ren aipamen bibliografikoz osotutako bi orri. Lehen orriak Noelac-en hiru argitarapen desberdinen berri

${ }^{17}$ Aita Larramendiren jarraitzaile dugu FI. Lécluse: honek bere Euskal Gramatikan (Lakarra 1987: 843) honela dio: «Le peu de livres imprimés en basque, qui soient parvenus a la connaissance de ce savant jésuite - Larramendi-, se réđuit aux suivants: [...] $4^{\circ}$ Noëls, et autres nouveaux Cantiques spirituels, par Jean Etcheberri, docteur en théologie: Bayonne, 1630, in-12\%. $5^{\circ}$ Autre volume du même auteur, sur le même sujet. intitulé: Manuel de dévotion». 
dakargu; hona zer dioen:

Noclac eta berce canta espiritual berriac. Jesus Christoren biciaren misterio proncipalen gañean. Eta sainduen ohoretan besta buructacotz. Joannes Etcheberri doctor Teologoac éguińciac (r)guinac).

Bayonan, P. Fauveten, imprimerian Carmessetaco aldean -..- Sans date --.- pagination, titré compris 1 à 250 .

L'approbation, datée de Saint Jean de Luz l'anût 1630 est signée P. de la Masse curée de Saint Jean de Luz et $P$. de Urhubie docteur en theologic.

La licence, signée par d'Oiherard, vicaire général est donée à Baione 8 aoùt 1630.

Mais n'indique en quelie amné ce livre a été imprimé, seulement on a placé au dos du livre le titre avec la daté 1630.

Sous la mème reliure vient une autre edition. Le titre est absolutemente le même; à l'erratum ęguinciac, on a substitué une autre faute egniñac.

au bas, on lit

Bordelen, Guillen Milanges Erregueren imprimatçaillea baithan. 1645. pag. titre compris 1 à 251 .

Les approbations et license sont exactement reproduits la table.

Les noels contenues dans cette edition ocupent jusqu'à 240, les autres pages sont ocupées par

Dans la premiere edition il n'y a pas de lable, mais on trouve deux noels de plus, entre antres celui qui commence par les mots suivanis Jesus hauncho larru dedicatua:

Gure gatic çure dolloratua:

Corcigarreneco odo...tua

La troisiéme édition, pour la méme couverture, porte le même titre que les deux premieres, avec l'erratum egniñac.

au bas on lit

Baionan, Maffre baitan bors Cantognetan. 1699. Cette edition est la reproduction exacte de celle de 1645, sans la table.

Itxuren arabera, bada, eskuizkribu honen kasuan ere, L. L. Bonaparte Printzearen lankide edo laguntzaile baten aurrean gaude eta honek, besteren arlean, lortu, ezagutu edo eskuetan izan dituen Noelac eta Eliçara erabiltceco liburua-ren berri damaio Printzeari.

Eskuizkribuaren irakurketatik ondorioztatzen dugu, bestalde, aipatzen dituen hiru argitarapenak batean bilduak direna («sous la même relieure» eta «pour la méme couvertures dio).

J. Vinsoni esker dakigu (1891-8: 73), gainera, Londreseko British Museum-ean dauden Noelac-en hiru argitarapen desberdinak (bere sailkapenaren arabera, 15b, 150 eta $15 \mathrm{f}$ ) ale batean, berean, direla bilduak; $15 \mathrm{f}$ edizioa da, bestalde, amaieran bertso beriak dituen lehena. Argi dago, bada, herritar honek aipatzen duen hau eta British Museumekoa bat direla.

Eskuizkribuaren kontua alde batera utzi eta jarrai dezagun J, Vinsonekin. Bera izan da edizio guzti hauek sailkatzen ahalegin gehien egin duena. Eta ez da lan erreza sailkapen hau burutzea. Edizio batzuk ez dakarte argitaratze datarik eta honek zaildu egiten ditu lanok. Jarraian bere Essai...-n aurki ditzakegun argitarapen desberdin guztiak (1891-8: 68 hh) erakutsiko ditugu, banan banan. 


\subsubsection{15a edizioa}

"15a.-NOELAC ETA BERCE canta elpiritual berriac. Iesus Chriftoren biciaren myfierio principalen gañean. Ela 「ainduen ohoretan belta buruetacotz. Loannes Etcheberri Doctor Theologoac eguinac. BORDELEN, G. MIllanges, 1630 ou 1631."

Lehenengo argitarapen hau berak suposatutakoa besterik ez da, eta 1630 edo 1631.ean kokatzen du. Bere ustez zilegi dirudi, baimenen datak ikusita, urte horietan argitaratua izan zitekeela adieraztea, ziurrenik Gilen Milangesenean argitaratua gainera. Ez du uste Vinsonek 1630.ean baimena lortu eta 1645.era arte inprimatu gabe izango zenik. Ez zuen, haatik, lehen argitarapen honen alerik aurkitu.

Louis Desgravesen Les livres imprimés a Bordeanx au XVIF siécle liburuan (1971: 100), argitarapen honen berri dugu. Bertan «D'apres Vinson (Bibliographie), p. 76. n 17 a) irakurtzeko aukera dugu. Maiz gertatzen da bibliografo baten ustezko aipamena (Vinson, adibidez) hartu eta liburu hori argitaratua izan dela onartzea (Desgraves, adibidez). Izan ere, liburu honetan argitaratutzat du Desgravesek 1630.eko edizio hau eta Vinsonek argitaratua behar zuela izan baizik ez dio; are, ez dela alerik ezagutzen.

\subsection{5b edizioa}

"15b.-NOELAC I ETA BERCE I canta elpiritual I berriac. I lefus Chriftoren biciaren my- I flerio principalen gañean. I Ela lainduen ohorelan befa buruetacolz. I Inannes Elcheberri Docior I Theologoac egniñac: I (fleuron) I BORDELEN. I GVILLEN MILANGES, Erte- I gueren Imprinatçaillea I baithan, 1645."

In-8 txikia erakoa, 251 orrialde. Neurriak: $45 \mathrm{~mm}$ x 98 . Zeinadurak: A p. I, B p. 17 , C p. 33, e.a.

P. de la Masse Donibane Lohitzuneko apaizak eta P. de Urthubie Teologian doktoreak baitetsia, 1630.eko abuztuaren 6an. Baimena, Manual-ean legez, M. d'Oiharard Bikario Jeneralarena da, urte eta hilabete berbereko egun bi beranduagokoa, $8 \mathrm{koa}$. Joan Ihartius eta Stefano Hirigoitiren laudoriozko bertsoak eta P. Argaiñarats-en akrostiko bat dakartza.

Londresko British Museum-ean lortu genuen argitarapen honen fotokopia bat J. A. Arana Martijari esker.

Desgraves jaunak ere Vinsonen aipamena jartaitu du 1645.eko argitarapen honen berri emateko bere Les livres imprimés a Bordeaux.. liburuan (1971:122). Ez du, gainera, ezer berririk aipatzen eta ez dirudi alerik ezagutu duenik.

\subsubsection{15 c edizioa}

"I5c-NOELAC I ETA BERCE I canta efpiritual I berriac. I lefus Chriftoren biciaren I mifterio principalen I gañean. | Eta lainduen ohoretan befa | buruetacotz. | Joannes ETCHEBERRI Dolor | Teolegoac : egniñac. | (croix entre deux petits fleurons) | BAIONAN, | MAFFrE Baitan bors | 
Cantognetan. 1697." ${ }^{18}$

In-8 txikia erakoa, 240 orrialdetakoa da. Neurriak: $44 \mathrm{~mm}$ x 96. Zeinadurak: A p. 1. B p. 16, C p. 25. D p. 41, E p. 49 , e.a.

Baimenak, onespen ela laudorioak besteetakoak dira, ar,itarapen eta berrargitarapen guztietan bezalaxe.

Argitarapen honen ale baten fotokopia bat Donostiako Urkixo Liburutegian lortu genuen. Beste ale baten fotokopia Chicagoko Newberry Library-n lortu genuelakoan geunden biak konparatu eta aztertzen hasi ginen arte. Azterketa honek, ordea, bi argitarapen desberdinen aurrean gaudekeela erakutsi digu. Hurrengo orrialdeetan ezarri ditugu bi ale haucn konparaketak eragin dituen zerrendak. Argi erakusten dute zerrendok ez dela posible edizin burburcko bi ale desberdinen aurrean izatea. Hona hemen desberdintasun nabarienak:

$\neg$ Zenbait orrialdetan, lerro kopurua betetzeko, tarteka-marteka jari ohi diren orla-k nahiko desberdinak disa bi aleetan (ikus. 3, 6, 9, 11, 13, 25. 31, 40, 169, 178 eta 213. orrialdeetan agertzen direnak).

-210-213 orrialdeetan, lerro bateko desoreka dago bi aleen artean.

$\neg$ G/G: Chicagoko Newberry Library-ko edizioan, beti dugu G. Urkixoko alean, ordea, beti $G$

$\rightarrow H / H$ : Bi aleetan, $H$ maiuskulak agertu behar duen tokian, sami, batean $H$

: 8 Baionako artriboek, 1636.az geroztik, Maffe liburudenda baten aipamena dute; litekeena da Maffre hau Bordeleko Milangesdarren ordezkaria izatea, 1620. urtean Baionako hiriari liburudenda baten alokairua ordaimtzen zioten Milangesdarrena; Jean Maffre, hauen artean. Salerosle-liburusalizaile izan zen Salie-n, Port-deCastets edo Pont-Magou kalea, egoera zibilaren akten arabera; Bosi Cantonetan, bere izena daramaten liburuenera (Eixeberriren Noelac, 1697 eta 1699.eko argitaraldiak).

1705.eko abenduaren 27an híl zen. 7 seme-alaba izan zituen. Berajetariko bat, Saubade, aitaren jarraitzaile izango duguna, 1669.eko irailaren 28 an jaio eta 1715 eko abenduaren 9an hila. 1707. eko otsailaren $28 \mathrm{ko}$ Kontseilu Erabaki batek zera dio. Amaud Verdier-Maffre liburusaltzaile besterik ez dela izango. 1742.ean Forest jaunari saltzen dizkio funtsak, lsonek bere enplegatuetariko bat (Jean François Trebosc) bidaltzen duelarik postuaren kargu egitera. Fauvetdarrak ez datoz bat erabaki honekin enplegatu hau inolako aprendizko gabea zela uste baitzuten. Prozesuaren datuen arabera, Verdier-Maffreren denda Poni-Mayou kalean, Jean Fauvetena Orbe edo Vieille-Monnaine kalean eta Fauveten alargunarena Orbe kale horretan, kantoian, Karmeldarrengandik hurbil, daude. Jean François Trebosc-ek Bancel delako baten esku uzten ditu bere funtsak lraultzaren garaietan. M. Gosse izan zen Bancel honen ondorengo eta M. Mocodiain M. Gosse honena.

Patentea ordaintzen zuten inprimatzaile eta liburusaltzaileek izaten zituzten eskubideak zirela medio, zeloak ugaritu egiten ziren behar ez zen kontrabandoa sortuz. Fauv:-_-Jarren artean ere istilu ugari sortu zíren, hain ziren nabarmenak konperentzia eta konkurrentzia. 1767.eko 'diktuaren ondorioz, beste laugarren liburusaltzaile plaza berria eratzen da Baionan. Lau plazok Trebosc, Paul Fauvet-Duhart, Pierre Fauvet eta Thomas Dhiribarrenen esku izango dira.

1766.az geroztik, Jean Cluzeau liburusaltzailearen izena aurki genezake egoera zibilaren aktetan. Dhiribarrenekin elkanu zelako? Bere ondorengoa izan zelako? Zena zela, hurrengo urteetako ukretan liburusaltzaile, inprimatzaile eta koadernatzaile gisa agertzen da. Bere semeek jarraitu zuten aitaren lanarekin. 
maiuskula hori dugu; beste alean, ordea, $\mathrm{H}$ bersalita. Beste behin, h minuskulak agertu behar duen tokian ere agertzen da $\mathrm{H}$ bersalitori.

$\neg$ I/J: Chicagoko alean, beti aurkituko dugu I hitz hasicran: Urkixokoan, I.

$\rightarrow \mathrm{K} / \mathrm{K}: \mathrm{H}^{\prime} \mathrm{H}$ kasuan gertatzen zen berbera dugu hemerı ere.

$\neg$ U/V: Chicagoko alean, $V$ aurkiluko dugun bitartean, Urkixokoan $U$ izango da arruntena hitz hasieran.

$\neg \mathrm{z} / \mathrm{z}$ : Bata zein bestea agertzen dira. Bata behin ale batean, bestea bestean.

$\neg$ Eranskinean ikusiko dugunez, bi aleetan hitzak desberdin ebakiak daude adibide askotan.

$\rightarrow$ Puntuazio markak ere aldatu egiten dira ale batetik bestera.

$\neg$ Badago $n / \bar{n}, n^{\prime}$ txandaketa bi aleetako zenbait adibidetan.

- Txistukari frikari zein afrikarietan ere txandaketa gertatzen da kasu batzuetan.

Aipatu bezala, aurkitu ditugun bi aleen arteko desberdintasun guztiak jarraiko lerroetan doazkizue, eta desberdintasunon aurrean zilegi dirudi bi edizio desberdinen aurrean aurkitzen garela aitort/cat ita ez edizio berberaren bi ale desberdinenean.

Zerrendak nola banatu ditugun argitzearren, derragun bost zutabe desberdin aurkituko ditugula orrialdeotan zehar:

1. zutabea $\Rightarrow$ orrialde zenbakia

2. zutabea $\Rightarrow$ bertso zenbakia

3. zutabea $\Rightarrow$ Chicagoko New Berry Library-ko Luis Luziano Bonaparte Printzearen liburutegiko funtsetan lortu dugun alearen aldaerak.

4. zutabea $\Rightarrow$ Gipuzkoako Foru Aldundiko Urkixo liburutegian lortu genuen alcaren aldaerak.

Lehen zutabeko orrialde zenbakiari buruz zera adierazi behar dugu, bi edizioak datozela bat orrialde kopuruan, bi edizioak dutela taiuera berbera (lerro kopuru berbera orrialdeko eta lerroen luzeera berdintsua). Horren ondorioz. orrialde zenbaki bat baizik ez dugu.

Bertso zenbakiari dngokionez zera azaldu behar da, hiru zenbatze era desberdinen aurrean aurkituko garela. Bertsoak beraiek ditugu, batetik, zenbaki normalez zenbatuak. Bertso sorla edo ahapaldi desberdinen izenburuak eta azpi-izenburuak, bigarrenik, $1 Z 1$, IZ2, IZ..n kodea dute, izenburu hori lehen, bigarren.... lerrokoa dela adierazteko. Bertso edo izenburu ez den lerroak, azkenik, 1L. 2L. n...L kodea du (lehen lerroa, bigarren lerroa....), orrialde bakoitzean berriz hasten delarik zenbatze-prozesua.

Zerrendotan azaltzen ditugun aldaerez landa, badaude azpimarratu nahi genituzkeen honako kontuook:

- Konparaketari ekin diogunean aurki ikusi dugu, inprentan, bertso sorta, ahapaldiak eta atalak banatzeko, orrialde buruetan eta horrelakoetan agerizen direan orla gisakoak (inprenta eta edizio bakoitzan bereak dituen arren, hurrengo hau izan daiteke orla gisako 


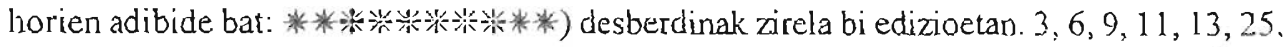
31, 40, 169 eta 178. orrialdeetan agertzen direnak, horren erakusgarri. 213. orrialdean, bestalde, Urkixoko alean orla agertzen den bitartean, Chicagokoan ez dago.

- Urkixoko alean, 210. orialdeak 20 testu lesto ditu; Chicayokoan, 19. Hurrengo orrialdeetan lerro bateko desoreka dugu, beraz. 2 14. orrialdean berriro ditugu berdindurik bi aleak, aurrekoa, 213.a, ez baita 20 lerroz betetzen.

- 3. orrialdean, kapitulua hasteko hizkia (kanitularra) oso desberdira da bi edizioetan. Chicagokoan oso estua da; Urkixokoa, aldi\%, nahiko zabala.

- 224. orrialdean, azken lerroko 'Larrera egotztera' dugu. 'Larrera' hitzaren lehen hizkia eroria dago Chicagoko alean.

- 116. orrialdean, Urkixoko alean, 116. bertsoa C kapitularraz hasten da. C honek badu azpian, (c hautsiaren marra) jarria, norbaitek eskuz jarria bezala. Hitza 'Cauri' eta $\mathrm{C}$ horrek badu bamean z bat, hau ere norbaitek eskuz egina.

Demagun, azkenik, bi edizioen konparaketak eragin duen aldaeren zertenda:

\begin{tabular}{|c|c|c|c|}
\hline Ortial. & Bertso. zen. & Chicagoko edizioa & Urkixoko edizioa \\
\hline 003 & 123 & LAVNARI & IAUNARI \\
\hline 004 & $001 \mathrm{~L}$ & elkharri & elkharti \\
\hline 005 & $006 \mathrm{~L}$ & cguiña, & eguin̄a, \\
\hline 005 & 007L & baitugu & ba tugu \\
\hline 005 & 10L & deuotionean & devotionean \\
\hline 005 & $1 Z 4$ & VRTHVBIE & URTHUBIE \\
\hline 006 & $006 \mathrm{~L}$ & Ioanne & goanne \\
\hline 007 & $005 \mathrm{~L}$ & Pyerides & Pierides \\
\hline 007 & 124 & IOAN & JOAN \\
\hline 007 & IZ8 & IOAN & gOAN \\
\hline 009 & 003L & Gure & Gure \\
\hline 009 & 008L & Berriz & Berriz \\
\hline 009 & 014L & Guztientfal & Guztientfat \\
\hline 009 & 0141 & Guztientcat & Guzlientfal \\
\hline 009 & $014 \mathrm{~L}$ & azpiko & azpiko \\
\hline 009 & $015 \mathrm{~L}$ & Ercheberric & Eicheberric \\
\hline 009 & LZ1 & IOANNES & gOANNES \\
\hline 011 & 124 & HVNEN & HUNEN \\
\hline 012 & $007 \mathrm{~L}$ & Iajncoren,eta & Iaincoaren, eta \\
\hline 013 & $002 \mathrm{~L}$ & dire, Lehenbj- & dire. Lehenbi- \\
\hline 013 & $005 \mathrm{~L}$ & Gaucē & Gauce \\
\hline 013 & IZI & HVNEN & HUNEN \\
\hline 013 & [Z] & LIBVRVTCHO & LIBURLTCHO \\
\hline 016 & 0039 & captiuo & captivo \\
\hline
\end{tabular}




\begin{tabular}{|c|c|c|c|}
\hline 017 & 0070 & Khoroa & khoroa \\
\hline 017 & 0074 & iharrollico & iharrottico, \\
\hline 018 & 0089 & Bathleengo & Bethleengo \\
\hline 018 & IZ2 & Erech. & Ezech. \\
\hline 020 & & 20 & 02 \\
\hline 020 & $I Z 4$ & Abendocotz & Abendocotz \\
\hline 021 & 0129 & Eikhar & $\mathrm{E}(?) \mathrm{khar}$ \\
\hline 021 & 0132 & aurkhitu & aurkhitu \\
\hline 0212 & 3887 & ontaflunetara & ontaffuletara \\
\hline 022 & IZ3 & Abendocorz & Abendocotz. \\
\hline 022 & IZ6 & Helespontica & Helefpontica \\
\hline 026 & 0210 & Gur & Gut \\
\hline 026 & 0214 & conuerlatu & converlatu \\
\hline 026 & 0218 & Vtci & Utci \\
\hline 027 & $\mathrm{IZA}$ & Ejearaz & Efcaraz \\
\hline 029 & 0267 & Hill. & Hill \\
\hline 029 & 0268 & inuiatcera & inviatcera \\
\hline 029 & IZ3 & Iacobus.s & gacobus \\
\hline 030 & 0285 & LAu & LAur \\
\hline 030 & [Z] & Iudas & Judas \\
\hline 031 & 0300 & bicitcea & bicitcea. \\
\hline 031 & $I Z I$ & Gabriel & Gabriel \\
\hline 032 & 0318 & Vrrearen & Urrearen \\
\hline 034 & 0365 & Vngui & Unguj \\
\hline 035 & 0367 & Vngui & Ungui \\
\hline 036 & 17.1 & Gabrielec & Gabrielec \\
\hline 037 & 0412 & Khurtcen & khurtcen \\
\hline 037 & 0414 & vohatua & unhatua \\
\hline 037 & 0417 & Vngui & Ungui \\
\hline 037 & 0419 & Vngui & Ungui \\
\hline 037 & 0425 & ikhufi & ikhuilī \\
\hline 038 & 0427 & lekhutic & lekhutic \\
\hline 038 & 0429 & Vngui & Ungui \\
\hline 038 & 0431 & Vngui & Ungui \\
\hline 038 & 0433 & Vfte & Ufte \\
\hline 038 & 0435 & Ikbuftera & Ikhuftera \\
\hline 038 & 0445 & Vagui & Ungui \\
\hline 040 & 0471 & Bera & Beta \\
\hline 040 & LZ3 & IESVS & JESUS \\
\hline 040 & $\mathrm{~J} Z 3$ & IESVS & JESUS \\
\hline 040 & 175 & gañean & Gañean \\
\hline 040 & IZ6 & vesperacotz. & wesperacotz \\
\hline 041 & 0476 & Auguftoren & Auftoren ${ }^{19}$ \\
\hline
\end{tabular}

1. 'Auftoren' jarriagatik, aurreko orrialde barreneko deia osorik dago, 'Auguftoren'. 


\begin{tabular}{|c|c|c|c|}
\hline 014 & (1)484 & lekhuetan & lekhuetan \\
\hline 042 & 0503 & ekharri & ekharri \\
\hline 042 & 0510 & erakhari & erakharri \\
\hline 042 & 0518 & hirira. & hirira. \\
\hline 047 & 0602 & Mira culuz & Miraculuz \\
\hline 047 & 0606 & vngui vnhatu & ungui unhatu \\
\hline 047 & 0608 & Vngui & Ungui \\
\hline 048 & 0613 & vtzquitçue & ulzquitçue \\
\hline 048 & 0624 & fortceco, & fortceco. \\
\hline 048 & IZI & $\operatorname{le} \int u s$ & Jefus: \\
\hline 049 & 0634 & lekhu & leku \\
\hline 049 & 0634 & lekhu & leku \\
\hline 050 & 0654 & dela, & dela, \\
\hline 050 & $1 Z 2$ & gameun & ganean \\
\hline 051 & 0670 & gaula, & gaua, \\
\hline 052 & 0702 & vrean & urean \\
\hline 055 & 0766 & Ioleph & Joleph \\
\hline 055 & $\mathrm{IZI}$ & Nola & - Lola \\
\hline 056 & 0772 & mintçatu & maintçatu \\
\hline 056 & 0774 & Haur & Haur \\
\hline 056 & 0781 & vngui & ungui \\
\hline 056 & 0786 & Haur & Haul \\
\hline 057 & 0792 & Hambat & Hanbat \\
\hline 057 & 0807 & Haurra & Hauña \\
\hline 058 & 0814 & Haurtchoaren & Haurtchoaren \\
\hline 058 & 0819 & Haurtho & Haurtho \\
\hline 059 & 0846 & gratia: & gratia: \\
\hline 059 & 0848 & Vngui & Ungui \\
\hline 060 & 0863 & guere & gure \\
\hline 061 & 0876 & Vtci & Utci \\
\hline 061 & 0881 & Vngui & Ungui \\
\hline 062 & 0902 & Fiñ & Fin \\
\hline 062 & 0906 & Gure & Cure \\
\hline 062 & 0908 & C.eure & Geure \\
\hline 063 & 0915 & Hedoietaric & Hedoietaric \\
\hline 063 & 0917 & vtz & utz \\
\hline 063 & 0918 & Hefpilletan & Hefpilletan \\
\hline 063 & 0929 & gauaz & hauaz \\
\hline 063 & 09.30 & Haguit & Haguit \\
\hline 064 & 0938 & Hots & Hots \\
\hline 064 & 0950 & Vici & Utci \\
\hline 064 & DEIA & Noca & Nola \\
\hline 065 & 0953 & GVztiac & GUztiac \\
\hline 065 & 0966 & itpia & tipia \\
\hline 066 & 0973 & Vrrunago & L'rrunago \\
\hline 067 & 1008 & harturic. & harluric. \\
\hline
\end{tabular}




\begin{tabular}{|c|c|c|c|}
\hline 068 & 1025 & cioten, & cioten. \\
\hline 069 & 1033 & iuiatu & iviatu \\
\hline 069 & 1038 & Herodes & Herodes \\
\hline 070 & 1053 & vrgullua & urgullud \\
\hline 071 & 1077 & Carri. & larri \\
\hline 071 & 1078 & Batçartean & Barçartean \\
\hline 073 & 1108 & vrean & urean \\
\hline 073 & {$[Z]$} & lefus & Jefus \\
\hline 074 & 1141 & Vme & Une \\
\hline 074 & 1147 & vптеаz & umeaz \\
\hline 075 & 1161 & Ioleph & Joleph \\
\hline 076 & 1182 & Ioreph & Joleph \\
\hline 076 & 1187 & Iolephec & Jolephec \\
\hline 077 & 1195 & Vftez & Uftez \\
\hline 077 & 1198 & Gauaz & Gauas \\
\hline 078 & 1219 & Eceñi & Ecen \\
\hline 079 & 1225 & Herodes,bel- & Herodes, be- \\
\hline 079 & 1240 & baitçuen ${ }^{201}$ & Baitçuen \\
\hline 079 & IZI & Vrgulleriaren & Urgulleriaren \\
\hline 080 & 1253 & vrgulluac & urgulluac \\
\hline 080 & 1257 & Herodulliee & Herodeflec \\
\hline 080 & 1262 & Hill & Hill \\
\hline $08 \mathrm{l}$ & 1268 & vnhatcen & unhatcen \\
\hline 082 & 1292 & vftean & uftean \\
\hline 083 & 1303 & vrthetaraño & urthetaraño \\
\hline 083 & 1306 & ingurucoae & ingurucoac \\
\hline 084 & 1328 & Vrricaldu & Urricaldu \\
\hline 084 & 1336 & Vtci & Uici \\
\hline 084 & 1341 & Herodillec & Herodelíec \\
\hline 085 & 1348 & Iolephec & Jolephec \\
\hline 085 & 1349 & vngui & ungui \\
\hline 087 & 1391 & $\mathrm{vtz}$ & ut? \\
\hline 087 & 1392 & vmeac & umeac \\
\hline 087 & 1403 & vzten & uzten \\
\hline 088 & 1407 & $v r$ & us \\
\hline 090 & IZ2 & vrthe & urthe \\
\hline 090 & IZA & Noela & - finela \\
\hline 091 & 1466 & vtci & utci \\
\hline 091 & 1469 & lefus & Jerus \\
\hline 091 & 1475 & Iefus & Jefus \\
\hline 092 & 1493 & Vngui & Ungui \\
\hline 092 & 1495 & deuotionerequin & devotionerequir \\
\hline 092 & 1499 & Iefuffen & JefulГen \\
\hline
\end{tabular}

(1) A hapaldia hasiko bailuen, hitzaren aurretik bi hutsune dago. 


\begin{tabular}{|c|c|c|c|}
\hline 093 & 1506 & Iefus & Jefus \\
\hline 093 & 174 & Candelerocotz. & Candelerocotz. \\
\hline 094 & 1528 & Haren & Haren \\
\hline 094 & 1529 & Huna & Huna \\
\hline 094 & 1530 & vfo & UITo \\
\hline 094 & 1540 & Ioleph & Joleph \\
\hline 095 & 1547 & Deuotqui & Devotqui \\
\hline 095 & 1549 & vtzten & utzten \\
\hline 096 & 1573 & Ioleph & Joleph \\
\hline 096 & 1581 & Iofeph & Joleph \\
\hline 096 & IZI & Ielus & Jerus \\
\hline 097 & 1587 & Ioreph & Joleph \\
\hline 097 & 1591 & Vitez & Uftez \\
\hline 097 & 1598 & Vrrum & Urrum \\
\hline 097 & 1599 & Ielus & Jefus \\
\hline 097 & 1602 & vftean & uftean \\
\hline 097 & 1603 & vtci & utci \\
\hline 098 & 1623 & lefus & Jelus \\
\hline 099 & 1631 & vtci & utci \\
\hline 100 & 1653 & Ioleph & Joleph \\
\hline 101 & 1674 & pilatu & pilatu, \\
\hline 101 & 1677 & Iudeaco & Juideaco \\
\hline 101 & IZ2 & LIBVRVTCHO & LIBURUTCHO \\
\hline 101 & 122 & HVNEN & HLVIN \\
\hline 101 & $I Z A$ & IESUS & JESUS \\
\hline 101 & IZ8 & lelus & Jefus \\
\hline 101 & IZ9 & lartcearen & lortcearen \\
\hline 102 & 1688 & Deuotqui & Devotqui \\
\hline 102 & 1696 & vlaturic & ulaturic \\
\hline 103 & 1710 & ingurateco, & ingurateco: \\
\hline 103 & 1713 & vtcico & utcico \\
\hline 104 & 1737 & Vngui & Ungui \\
\hline 104 & IZ3 & $\mathrm{il} / \mathrm{hi}$ & ilkhi \\
\hline 105 & 1739 & Vngui & Ungui \\
\hline 105 & 1746 & Hirico & Hirico \\
\hline 105 & 1748 & Hain & Hain \\
\hline 105 & 1750 & bidea, & bidea, \\
\hline 105 & 1758 & Hitzten & Hitzten \\
\hline 106 & 1775 & deuotione & devotione \\
\hline 106 & 1779 & Han & Han \\
\hline 107 & 1782 & Hitz & Hitz \\
\hline 107 & IZI & bekhaiz- & belihaiz- \\
\hline 108 & 1820 & Handirequin & Handirequin \\
\hline 109 & 1833 & Hala & Hala \\
\hline 109 & 1839 & HeC & $\mathrm{Hec}$ \\
\hline
\end{tabular}




\begin{tabular}{|c|c|c|c|}
\hline 110 & 1844 & Ielus & Jefus \\
\hline 110 & 1846 & iruidia & invidia \\
\hline 110 & 1850 & Herrofloec & Нетоाтоес \\
\hline 110 & $1 Z 1$ & Inuidia & Invidia \\
\hline 110 & IZ1 & lefus & Jefus \\
\hline 111 & 1859 & vizten & utzten \\
\hline 111 & 1861 & Yelus & Jelius \\
\hline 112 & 1882 & Hura & Hura \\
\hline 112 & 1886 & iuiatu & iviatu \\
\hline 113 & 1918 & Cortean & Cotican \\
\hline 113 & 1919 & lugearen & Jugciren \\
\hline 114 & 1923 & inuidia & invidiai \\
\hline 114 & 1929 & Vrricalduric & Unticalduric \\
\hline 114 & 1929 & vtcico & utcico \\
\hline 114 & 1930 & vitean & uftean \\
\hline 114 & 1940 & vriz & uriz \\
\hline 115 & 1942 & vfpelez & ulpelez \\
\hline 115 & 1953 & TVgeori & IUgeori \\
\hline 115 & 1958 & Tefus & Jefus \\
\hline 115 & 1960 & illkhitcerá & illkhitcera \\
\hline 116 & 1970 & Vrratfic & Unatfic \\
\hline 116 & 1974 & Haren & Haren \\
\hline 116 & 1976 & Hartan & Hartan \\
\hline 117 & 1988 & Haren & Haren \\
\hline 117 & 1994 & Haren & Haren \\
\hline 117 & 1998 & Handitan & Handitan \\
\hline 117 & 1999 & Hequin & Hequin \\
\hline 117 & 2003 & Hill & Hill \\
\hline 119 & 2025 & Iudas & Judas \\
\hline 119 & 2028 & vrkhatu & urkhatu \\
\hline 120 & 2050 & Hambat & Hambat \\
\hline 120 & 2051 & Hirurgarren & Hirurgarten \\
\hline 120 & 2057 & GVrutcearen & GUrutcearen \\
\hline 120 & 2059 & Iefus & Jefus \\
\hline 120 & 2064 & Barkha & $\mathrm{Ba}$ ha \\
\hline 120 & 2064 & omenac, & omenac. \\
\hline 121 & 2074 & Iugearen & Jugearen \\
\hline 122 & 2107 & loleph & Joleph \\
\hline 123 & 2115 & Ioleph & Joleph \\
\hline 1.23 & 2123 & lerus & Jelus \\
\hline 123 & 2124 & kats & Kals \\
\hline 123 & 2127 & ontaITum & ontalfun \\
\hline 123 & IZI & Gurutcearen & Gurulcearen \\
\hline 124 & 2131 & lançaz & lançaz, \\
\hline 124 & 2133 & Ierus & Jefus \\
\hline 124 & 2135 & vngui & ungui \\
\hline
\end{tabular}




\begin{tabular}{|c|c|c|c|}
\hline 124 & 2139 & Deuotionez & Devotionez \\
\hline 124 & 2147 & Caluariaco & Calvariaco \\
\hline 125 & 2168 & Vrruitira & Urruitira \\
\hline 125 & 2174 & barkhatuco & barkhatuco \\
\hline 126 & 2180 & iaulfean & lauftean \\
\hline 126 & 2181 & oliua & oliva \\
\hline 127 & 2204 & lefus & Jelus \\
\hline 127 & 2213 & Ceru,lurreco & Ceru, Iurteco \\
\hline 129 & 2246 & Iefus & Jefus \\
\hline 129 & IZI & lefus & Jefus \\
\hline 130 & 2258 & pitztu & piztu \\
\hline 130 & 2258 & pitzu & pizrs \\
\hline 130 & 2271 & Vnguentu & Unguentu \\
\hline 130 & 2273 & Aainguerua & Ainguerua \\
\hline 131 & 2289 & Thomba & Tomba \\
\hline 131 & 2293 & Huna & Huna \\
\hline 132 & 2297 & unguenturic & unguenturic \\
\hline 132 & IZ3 & ekhar & elihar \\
\hline 133 & 2334 & Vngui & Ungui \\
\hline 134 & & Cala & \\
\hline 134 & 2344 & Aurkhitu & Aurkhitu \\
\hline 134 & LZ1 & Ieru & Jeru \\
\hline 135 & 2360 & vqui & uqui \\
\hline 135 & 2362 & Vquistu & Liquitu \\
\hline 135 & 2367 & Vquitu & Liquilu \\
\hline 136 & 2387 & IVdu & IUdu \\
\hline 137 & 2411 & lekhutic & lekutic \\
\hline 137 & 2411 & lekhutic & Iekutic \\
\hline 137 & 3395 & vrre & urre \\
\hline 138 & 2433 & lefus & $J(f u)$ \\
\hline 139 & 2438 & piz & pill \\
\hline 139 & 2439 & berac & betac \\
\hline 139 & 2444 & vici & utci \\
\hline 139 & 2448 & vrratu & urratu \\
\hline 139 & IZI & Iefus & Jefus \\
\hline 140 & 2456 & vrreizpiac & urreizpiac \\
\hline 141 & 2476 & vda & uda \\
\hline 142 & 2497 & çuien & çuten. \\
\hline 142 & 2500 & vithe & urthe \\
\hline 142 & 2500 & Gueroz & Gueroz \\
\hline 143 & 2514 & Vrgullua & Urgullua \\
\hline 143 & 2515 & baititu & baitutu \\
\hline 143 & 2518 & Vrrezco & Urrezco \\
\hline 143 & 2523 & Seraphiñac & Seraphinac \\
\hline 143 & IZI & Iefus & Je[us \\
\hline 144 & 2533 & Ol ibethco & OLibetcho \\
\hline
\end{tabular}




\begin{tabular}{|c|c|c|c|}
\hline 144 & 2544 & elkharren & elkharren \\
\hline 144 & 2547 & ekharri & ckharri \\
\hline 144 & DEIA & Ardiant & Ardiantchu \\
\hline 145 & 2553 & Gaixtoec & Gaiztoec \\
\hline 145 & 2553 & vRleco & ulteco \\
\hline 145 & 2558 & nckhaturen & nekhatu ren \\
\hline 145 & 2558 & nekhaturen & nekhatu ren \\
\hline 145 & 2562 & Caituzlela & Catiuztela \\
\hline 145 & 2569 & GVztiac & GUztiac \\
\hline 146 & 2573 & dohaccabeac & dohacabeac \\
\hline 148 & 2615 & Khorobat & Khorobat \\
\hline 149 & 2631 & ikhuा厂 & ikbuाi \\
\hline 150 & 2657 & Ielus & Jefus \\
\hline 151 & 2675 & Kharrezco & kharrezco \\
\hline 151 & 2681 & ilkhi & ilkhi \\
\hline 151 & 2683 & Erai teco & Etai teco \\
\hline 151 & 2683 & Eraiteco & Etai teco \\
\hline 152 & 2701 & Ielus & Jefus \\
\hline 152 & 2706 & Segurantçaz & Segurançaz \\
\hline 153 & 2721 & Iefus & Jefus \\
\hline 157 & 2788 & VlTain & UTrain \\
\hline 157 & 2801 & Iefus & Jefus \\
\hline 158 & 2825 & Oriente, & Oriente, \\
\hline 158 & 2828 & vniuerioan & univerloan \\
\hline 160 & 2855 & vizten & utzien \\
\hline 160 & 2871 & Hau & Hau \\
\hline 161 & 2889 & vquitcea & uquitced \\
\hline 161 & 2890 & trumpatce & trumpatcen \\
\hline 162 & 2900 & Hemen & Hemen \\
\hline 163 & 2917 & Arren & Aren \\
\hline 163 & 2922 & lefus & Jefus \\
\hline 163 & 2929 & Iefus & Jefus \\
\hline 164 & 2937 & GVirifinoac & GUiriftinoac \\
\hline 164 & 2940 & Iuge & Juge \\
\hline 164 & 121 & Azken & Azken \\
\hline 165 & 2963 & Iugeari & Jugeari \\
\hline 166 & 2975 & Iugearen & Jugearen \\
\hline 166 & 2984 & Iugea & Jugea \\
\hline 166 & 2991 & ekharle & ekharle \\
\hline 167 & $30 \times 00$ & ederrean & ederiean. \\
\hline 167 & 3014 & vrricaldu & urricaldu \\
\hline 168 & DELA & Vrricaldu & Unricaldu \\
\hline 169 & 3040 & Vrricaldu & Urricaldu \\
\hline 169 & 3042 & Kharтera & kharrera \\
\hline 169 & 3043 & Vrricaldu & Urricaldu \\
\hline 169 & 3053 & lefus & Jelus \\
\hline
\end{tabular}




\begin{tabular}{|c|c|c|c|}
\hline 170 & 3059 & bequiezquilçue & bequitzquitçue \\
\hline 170 & 3059 & Vrrical & Unical \\
\hline 170 & 3061 & Vrrical & Urrical \\
\hline 170 & $\mathrm{IZI}$ & vmea & umea \\
\hline 171 & 3078 & vrricaltcen & urricaltcen \\
\hline 172 & 3095 & Ioleph & Joleph \\
\hline 172 & 3102 & fauorea & Gavorea \\
\hline 172 & 3104 & Ielus & Jerus \\
\hline 173 & 3123 & fauore & favore \\
\hline 173 & 3132 & faure & favore \\
\hline 174 & 3141 & vrrical & urrical \\
\hline 175 & 3164 & V fatu & Ulatu \\
\hline 175 & 3165 & Vneed & Unea \\
\hline 175 & 3169 & Barkhá & Barkha \\
\hline 175 & 3173 & ikhuften & ikhuften \\
\hline 176 & 3190 & fauore & favore \\
\hline 177 & 3210 & fauore & favore \\
\hline 177 & 3215 & fauore & favore \\
\hline 178 & $I Z I$ & HVNEN & HUNEN \\
\hline 178 & IZ.J & HIRVR & HIRUR \\
\hline 178 & $1 Z 1$ & LIBVRVTCHO & LIBURUTCHO \\
\hline 178 & 17.10 & guţ̧az. & gutçaz \\
\hline 179 & 3225 & Vithearen & Urthearen \\
\hline 179 & 3237 & Akhabatu & Akhabatu \\
\hline 180 & 3252 & prouidentia & providentia \\
\hline 184 & 3320 & billkhu & billkhu \\
\hline 184 & 3322 & Fauoratcen & Favoratcen \\
\hline 184 & 3323 & fauore & favore \\
\hline 184 & 3328 & Airea & Aitea \\
\hline 184 & IZ2 & -rjieazkenecotz & Afieazlenecolz \\
\hline 185 & 3355 & Eua & Evá \\
\hline 186 & 3363 & Fauora & Favora \\
\hline 187 & 3383 & Inuidiaz & Invidiaz \\
\hline 187 & 3393 & Saluatore & Salvatore \\
\hline 187 & 3395 & Iuiatcera & Iviatcera \\
\hline 188 & 3412 & fauorea & favorea \\
\hline 189 & 3416 & Kharez & kharrez \\
\hline 189 & 3419 & Iauna & Iaunac \\
\hline 189 & $343 \mathrm{~L}$ & deuot & devot \\
\hline 190 & 3438 & fauorea & favorea \\
\hline 190 & 3442 & bakharric & bakharric \\
\hline 190 & 3451 & whe & urthe \\
\hline 190 & $1 Z 2$ & larumbatecoz & larumbatecotz \\
\hline 191 & 3459 & Tkhuftera & IKhuftera \\
\hline 191 & 3470 & Eskuñean & Eskuñean \\
\hline 142 & 3478 & Tefus & Jelus \\
\hline
\end{tabular}




\begin{tabular}{|c|c|c|c|}
\hline 192 & 3481 & vtcinic & utciric \\
\hline 192 & 3481 & $\mathrm{~V}_{\mathrm{I}}$ & $\mathrm{Ur}$ \\
\hline 192 & IZ2 & beftetacotz & befletacolz \\
\hline 193 & 3494 & Vrean & Urean \\
\hline 194 & 3513 & lefus & Jefus \\
\hline 194 & 3515 & vtci & utci \\
\hline 194 & 3518 & Azkenean & Azkenean \\
\hline 194 & 3520 & Vkhatcera & Ukhatcera \\
\hline 195 & 3534 & Telus & Jelus \\
\hline 195 & 3544 & fanorea & favorea \\
\hline 196 & 3553 & erakhani & erakharri \\
\hline 196 & 3556 & vkharacitcera & ukharacitcera \\
\hline 196 & 3556 & vkharacitcera & ukharacitcera \\
\hline 196 & 3561 & Ikhuffiric & IkhufTiric \\
\hline 197 & 3579 & Fauora & Favora \\
\hline 197 & 3581 & Saindua, & Caindua, \\
\hline 198 & 3590 & Vnguj & Unguj \\
\hline 198 & 3605 & Auarjciaric & Avariciaric \\
\hline 199 & 3615 & Vngui & Ungui \\
\hline 199 & 3617 & vngui & ungui \\
\hline 200 & 3632 & virats & urrats \\
\hline 200 & 3642 & nekhatuac & nekhatuac \\
\hline 201 & 3653 & deuoten & devoten \\
\hline 201 & 3660 & Nauffitçalt & Nauflitça \\
\hline 201 & 3662 & diligentena, & diligentena \\
\hline 201 & 3666 & azkenic & azkenic \\
\hline 202 & 3668 & Aurkhitcen & Aurkhitcen \\
\hline 205 & 3711 & vাrezco & urrezco \\
\hline 206 & 3754 & vrrezcoac & urrezcoac \\
\hline 206 & 3759 & fauore & favoie \\
\hline 207 & 3772 & altchatu & alchatu \\
\hline 207 & 3773 & devotequien & devotequien \\
\hline 207 & 3777 & egunac & eguinac \\
\hline 207 & 3784 & Deuoten & Devoten \\
\hline 207 & 3785 & Vmeac & Umeac \\
\hline 208 & 3792 & Ikhuften & Ikhuften \\
\hline 208 & 3805 & Vme & Ume \\
\hline 209 & 3810 & nekhatcen & nekhatcen \\
\hline 209 & 3823 & vmeac & umeac \\
\hline 210 & 3840 & fauorean & favorean \\
\hline 210 & IZ2 & Mikhelecotz & Mikhelecotz \\
\hline 211 & 3864 & lekhutic & lekhutic \\
\hline 212 & 3872 & caltetacoac. & caltetacoac \\
\hline 212 & 3875 & vriez & uriez \\
\hline 213 & 3892 & kharrean & kharrean \\
\hline 213 & 3907 & Vrrical & Unical \\
\hline
\end{tabular}




\begin{tabular}{|c|c|c|c|}
\hline 214 & $|Z|$ & LIBVRVTCHO & LIBURUTCHO \\
\hline 214 & $|Z|$ & HVNEN & HUNEN \\
\hline 214 & $\mathrm{DZ1}$ & LAVR & LAUR \\
\hline 217 & 3961 & elkhar & elkhar \\
\hline 218 & 3982 & erakharti & erakharri \\
\hline 218 & 3984 & Ioannes & Joannes \\
\hline 218 & 3997 & $v r$ & ur \\
\hline 219 & 4011 & b çare & baçare \\
\hline 220 & 4028 & lokharrien & lokharrien \\
\hline 220 & 4034 & Ikhaniei & IKhalliei \\
\hline 221 & 4043 & baian & bain \\
\hline 221 & 4058 & Burua & Buruac \\
\hline 223 & 4093 & Akhitzco & Akhitzco \\
\hline 223 & 4095 & ekharri & ekharri \\
\hline 224 & 4104 & Cini tuzten & Cinituzten \\
\hline 224 & 4109 & Iugcác & Jugeac \\
\hline 224 & 4112 & Vkbatcera & Ukhatcera \\
\hline 224 & 4112 & Vkhatcera & Ukhatcera \\
\hline 225 & 4128 & barkhatu & barkhatu \\
\hline 225 & 4136 & Vrruititic & Unuititic \\
\hline 225 & 4144 & IkhuITi & Ikhurti \\
\hline 226 & 4186 & azkennean & azkenenean \\
\hline 226 & 4186 & azkennean & azkenenean \\
\hline 227 & 4171 & $\operatorname{cirez}$ & ciren \\
\hline 227 & 4171 & Gorputz & Gorpuz \\
\hline 227 & 4184 & azken & azken \\
\hline 228 & 4196 & Deuoten & Devoten \\
\hline 228 & 4197 & fauore & favore \\
\hline 229 & 4206 & vkhatu & ukhatu \\
\hline 229 & 4210 & vmea & umea \\
\hline 230 & 4247 & Fauora & Favora \\
\hline 231 & 4260 & deuotetan & devotetan \\
\hline 231 & 4265 & vrez & urez \\
\hline 231 & 4269 & Trauailluac & Travailluac \\
\hline 232 & 4276 & vnbaturic & unhaturic \\
\hline 232 & 4281 & lelus & Jefus \\
\hline 232 & 4289 & vtci & Utci \\
\hline 233 & 4295 & Gambiatuco & gan biatuco \\
\hline 233 & 4298 & vrriquitu & urriquitu \\
\hline 233 & 4300 & conuertitu & convertitu \\
\hline 234 & 4319 & ordena & ordenac \\
\hline 234 & 4322 & Conuentu & Conventu \\
\hline 234 & 4324 & baiño & baino \\
\hline 234 & 4334 & Vrrunena & Urrunena \\
\hline 235 & 4345 & Patriarkha & Patriarkha \\
\hline 235 & 4350 & Ene & Eene \\
\hline
\end{tabular}




$\begin{array}{llll}235 & 4355 & \text { cargua } & \text { carguia } \\ 236 & 4360 & \text { foldaduac } & \text { foldaduac. } \\ 236 & 4370 & \text { vrguilluac } & \text { urguilluac } \\ 236 & 4371 & \text { Iefus } & \text { Jefus } \\ 237 & 4392 & \text { azkenac } & \text { azKenac } \\ 237 & 4398 & \text { conuertitcen } & \text { convertitcen, } \\ 237 & 4398 & \text { conuertitcen } & \text { convertitcen } \\ 238 & 4419 & \text { aurkhitu } & \text { aurkhitu } \\ 238 & 4805 & \text { Efcolac } & \text { Elcoluac } \\ 239 & 4425 & \text { Oraī } & \text { Orain }\end{array}$

Aurrerantzean, gure geure zerrenda eta lanetarako $15 \mathrm{c}$ eta $15 \mathrm{c}-1$ izendatuko ditugu: $15 \mathrm{c}$. Chicagoko Newbenty Library-ko Luis Luziano Bonaparte Printzearen funtsetan dagoen alerako; $15 \mathrm{c}-1$, Donostiako Urkixo liburutegian dugunerako. 15b argitarapenarekiko konparaketak zera erakutsi digu, posible dela Chicagoko argitarapena izatea haren hurrengo eta ez Urkixokoa (horregatik izendatu dugu 15c Chicagokoa eta 15c-1 Urkixokoa). Dena den, lanaren ariak berak erakutsiko du zuzen ala oker gabiltzan.

Hau da, izan, 15c izendatu dugun argitarapenaren aipamen bibliografikoa:

NOELAC I LTA BERCF I canta elpiritua! | berriac. I lefus Chrifloren biciaren I mifterio principalen I gañean. I Eta lainduen

ohoretan befta I buruetacotz. I Ioannes ETCHEBERRI Doctor I Teolegoac : egniñac. I (gurutze bat lore artean) I BAIONAN, I MAFFRE Baitan bors I Cantognetan. 1697.

\subsubsection{15d edizioa}

"ISd-NOELAC I ETA BERCE I canta elpiritual I berriac. I lefus Chriftoren biciaren I mifierio principalen I gañean. I Eta lainduen ohoretan befia I buruetacotz. I Joannes ETCHEBERRI Doctor I Teolegoac egniñac. I (croix entre fleurons) I BAIONAN, I MAFFRE Baitan bors I Cantognetan. 1699."

In-8 txikia erakoa, 240 orrialdetakoa. Edizio hau 1697koari dagokio hitzez-hitz eta Vinsonek data okerrekoa zela uste izango zukeen, hiru pertsona desberdinek hirurak 1699.ekoa irakurri zutela esan ezbaliote.

Oraingoan ere Londresen lortu genuen argitarapen honen ale baten fotokopia.

\subsubsection{15 e edizioa}

"15e.-NOELAC I ETA BERCE I canta elpiritual | berriac. I lefus Chriftoren biciaren I mifterio
principalen I gafiean. I Eta lainduen ohoretan befa buruetacotz. I Joannes ETCHEBERRI Doİ́r I
Teolegoac egnifiac. I (croix simple) I BAIONAN, I MAFFRE Bailan, bors I Cantognetan. I 699."

Hau ere in-8 txikia erakoa, 240 orrialdetakoa. (241 orrialde zenbatu dira, baina hau 89. zenbakia falta eta 88. aren ondoren 90. a datorrelako da. Zenbaki honetatik aurrera, bada, erako orrialdeak zenbaki pareak dituzte, ezpareak itzulitakoak.) Zeinadurak: A p. I, B p. 
17. C p. 25, D p. 41 , E p. 49, e.a. Neurriak: 41 mm. $5 \times 96,5$.

Berezitasun nabari bat dauka, 220. orrialdetik aurrera testuko letra desberdina da, askoz txikiagoa. Vinsonen ustez (1891-8: 70), argitarapen hau aurrekoaren faltsupena edo kontraegina da. Ez dugu argitarapen honen fotokopiarik eskuratzeko aukerank izan. bai, ordea, Donibane Lohitzunen Maria Josefa Lanuzarenean aurkitu dugun alea aztertzeko eta berezilasun guztien oharrak hartzeko.

Ikusi dugu 15a eta 15b (lehena benetar argitaratu zela suposatuz) argitarapenak Bordelen, Gilen Milanges erregearen inprimatzailearenean inprimatu zirela. Hurrengo laurak (15c, 15c-1, 15d eta 15e) Mafre bailan inskripzjoa dakarte.

\subsubsection{15f edizioa}

“I5f.-NOELAC I ETA BERCE I canta efpiritual | berriac. I Jefus Chrifioren biciaren I mifterio principalen I gañean. I Eta fainduen ohoretan befla I buruetacolz. I Joannes ETCHEBERRI Doctor I Teolegoac egniñciac. I (croix entre fleurons) I BAYONAN, I P. Fauveten, Imprimerian I CarmefTetaco aldean." 21

Hau ere in-8 txikia erakoa, 250 orrialdetakoa da. Zeínadurak: A p. I, B p. 17, C p. 25. e.a. Neurriak: $45 \mathrm{~mm} \times 95$. Betiko gaiak dakartza. Urkixo Liburutegian lortu genuen edizio honen fotokopia bat.

Argitarapen honen amaieran aumekoetan agertzen ez diren bertso sortak ditugu: 241. orrialdean verbum caroac; euskaraz; 245.ean clarilates guçia. Ama Mariari eskainitako abestia; 249. orrialdean lesus Haurtcho larru, lesusen zirkuntzisioari buruzko bertsoak.

Izan dugu edizio honen bi ale eskuartean erabiltzeko aukera. Bat Julio Urkixo Liburutegian dagoena eta bestea Londreseko British Museumekoa. Hauek dira gainbegirada azkau baten ondorengo bien arteko desberdintasunak:

Fauveidarren artean Antonio da ezagutzen dugun lehena. 1652. urtearen inguruan jaioa, oso gazte etorri zen Baionara eta 1667.az geroztik Baionako hiriak inprimatzaile soldara ordaintzen dio. 100.ean hiltzen da etá berak utzitako tokia Paul Fauvet bere semeak hartzen du 1700.eko maiatzaren $24 a n$.

1704.eko uztailaren 2 leko Estatu Kontseiluaren Erabaki batek Baionako inprimatzaile kopurua bitan jartzen du eta bigarren plaza hau Etienne Labonièrek hartzen du. 1725ean, uzzen duenean, Paul Fauveı eta bere seme Jeanek eskatzen dute, eskaera onartua delarik. Paul zaharra 1736.eko azaroaren 16an hil zen. 


\begin{tabular}{|c|c|c|}
\hline \multicolumn{3}{|c|}{ Noelac liburuaren. $15 \mathrm{f}$ edizioaren bi ale desberdinen konparaketa } \\
\hline or. & Urkixoko alea & Londreseko alea \\
\hline $\begin{array}{l}30 \\
98 \\
109 \\
110 \\
123 \\
208 \\
211 \\
219 \\
229\end{array}$ & 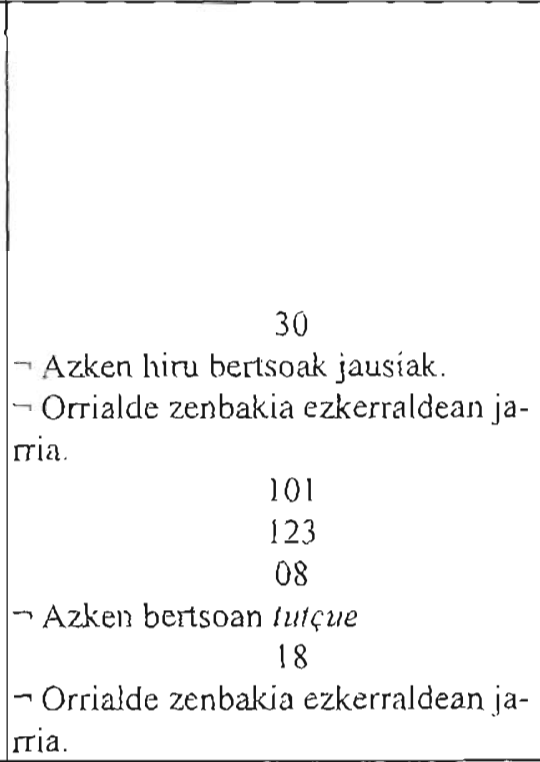 & $\begin{array}{l}\text { - Liburu-aurreko orrialdean, barre- } \\
\text { nean, 1682.eko data dago jarria eskuz. } \\
\text { Vinsonen ustetan (Vinson, 1891-8: } \\
71 \text { ), datu hau ez legoke ondo P. Fauvet } \\
\text { izeneko lehen inprimatzailea ez baita } \\
\text { 1700.az baizik inprimatzaile. } \\
\rightarrow \text { Bigarren zifra jausia. } \\
\rightarrow \text { Orrialde zenbakia eskumaldean ja- } \\
\text { ria. } \\
110 \\
\quad 8 \\
7 \text { iuçue-ren azken letra jausia. } \\
118 \\
\rightarrow \text { Orrialde zenbakia eskumaldean ja- } \\
\text { ria. }\end{array}$ \\
\hline
\end{tabular}

\subsubsection{7. $15 \mathrm{~g}$ edizioa}

"15g.-NOEL A I ETA I BERCE I CANTA | ESPIRITUAL BERRIAC. | Jefus Chrifioren hiciaren mifterio | principalen I gañean. Eta lainduen ohoretan belta ! buruetacotz. | Joannes ETCHEBERRI Doctor! Teolegoac egnifiac. I (3 fleurons, deux et un) I BAYONAN, I J. FAUVET, Imprimatcaillea I baithan. borı.Cantoiñetan." 22

Ilau da era desuerdincko bakirra, in-12koa, 204 orrialdetakoa. Zeinadurak: A p. 1, B p. 13, C p. 25, D p. 37, L. p. 49, e.a. Neutriak: $58 \mathrm{mn} \times 112$.

Argitarapen honek ere besteetan agurten ez diren bertso sorta batzuk ditu amaieran. 195. orrialdean, Stabat-en itzulpena: 198.ean, Gaudeac, Andra Mariari eskainiriko latinezko bertsoak; 200 . orrialdean, Stabat latinez, eta 202. orrialdean erregeari eginiko otoitza latinez.

Vinsonek zera dio, Jean Fauvet 1731. urtean hasi zela inprimatzen; 1760.ean hil zen. Argitarapen hau, beraz, data hauen artekoa dateke.

${ }^{2}$ Paul Fauvet hiltzen denean bere ondasunak bere alargunari uzten dizkio; honek bere seme Jeanekin bat egin zuen ondasun horien hustiakuntzarako. Jean Fauvet 1760.eko apirilaren 8 an hil zen; beraz, edizio hau 1731-1760 urte bitartean kokatu beharko genuke. 
Honen fotokopia bat ere Urkixo Liburutegian lortu genuen.

\subsubsection{15h edizioa}

"15 h.-NOELA I ETA BERCE I canta ipiritual berriac. I Iefus Chriforen hiciaren I mifterio principalen gañean. | Eta fainduen ohoretan bella I buruetacotz. I Joannes ETCHEBERRI Doclor I Teolegoac egnifac. | (croix simple) | BAYONAN, I P. FAUVET, Imprimatcaillea / baithan. Carmelen aldean" 23

In-8 txikia erakoa, 240 orrialdetakoa. Zeinadurak: A p. 1, B p. J7, C p. 25, D p. 41 , e.a.; neurriak: $45 \mathrm{~mm} \times 97$.

Argitarapen honetan, 211. onialdetik aurrera, letraren neurria txikiagoa da. Orain arte, testua besterik ez zuten orrialdeck 22 lerro izan badute, hemendik aurrera 27 izango ditute. Jean Fauveten argitarapenean amaieran agertzen diren bertso sorta berri berberak agertzen dira honetan ere.

Argitarapen honen fotokopia bat Chicagoko Newberry Library-n lortu genuen.

\subsubsection{15i edizioa}

"15i.-Noela l eta berce I canta fpiritual berriac. I Jisus Christoren mis I terio principalen gañean I Eia salnduen ohotetan besta I buruetacolz. I Joanncs Eucheberri, I Doclor Theolograx egnifiac. I Bayonan. I P. Fauvi:T, Imprimatcaillea I baithan, Carmelen aldean"

J Jean Fauveten anaia, Pierre Fauvel, Bordelen De la Court-ekin lan egina zena, bi aldiz izaten da harlua inprimatzaile-liburusaltzaile gisa; 1737 eko ekanaren 7 an bere aitaren tokian, eta 1757 .eko abenduaren 23 an bere amarenean.

Anne Boudérekin ezkondua, besteak beste, Pierre Hyacinthe Fauvet semea izan zuten, 1731 .eko martxoaren 27 an jaioa eta geroago bere aitaren tokia hartuko zuena, Fauvet gaztea izenez.

Litekeena da bere ama eta anaiarekin batera lan egitea 1757, erante, orduan baizik ez zuela bere nolóiztegi-liburudenda izango.

Jean Fauvet 1760 . eko apirilaren 8 an hil zen eta bere seme Paulek jarraitzen du bere tokian, 1760 .eko irailaren 1 Sean errege parentea lortu eta urriaren 6an dagielarik zin. Fauvet-Duhart edo Duhart-Fauvet izena jarzen du 1764.eko ekainaren 12 az geroztik. czkondu zen egunaz geroztik alegia. Inprenta berria ireki zuen Karmeldarren elizaren alchamenean, Tanneries kalean.

1791.eko urriaren $3 a n$ hil zen eta bere seme Pierre-Armand-Joseph-Pascalek, 1776.eko uztailaren 29an jaioa, hartzen du bere tokia.

1777. urteko inprimatzaileen Estatu orokorrean Baionan bi inprimatzaile daudela esaten da. Paul Fauvet eta Pierre Fauvel.

Pierre Fauvet edo Fauvet gaztea, eliz barrutiko inprimatzailea, ez dirudi lan gehiegıtan zebilenik. I781.eko apirilaren 22 an hil zen. Bere exxea, une batez bere anaia Paulek zuzendua da, Pierreren tokia bere seme Pierre-Hyacinthek harzen duen arte. 
In-8 txikia erakoa, 230 orrialdetakoa. Zeinadurak: A p. 1, B p. 17. C. p. 33, D p. 49 , e.a. Neurriak: 51 mm. x 89.

Honetan ere Jean Fauveten argitarapeneko bertso sorta beri berberak. 106. orrialdetik aurrera (bigarren ataletik aurrera, alegia) letraren neurria txikiagoa da (20 lerro honaino; aurerantzean 25. Beti ere, izenbururik ez dagoen lenoez mintzo gara; orrialde osoan testu normala).

Argitarapen honen bi ale desberdinen fotokopiak ditugu, Urkixo liburutegian eta Chicagoko Newberry Library-n lonuak. Bi aleak konparatuta, hau izan da alde gutxiena aurkitu dugun edizioa:

\begin{tabular}{||l|l|}
\hline \multicolumn{2}{|c|}{ Noelac liburuaren 15 i argitarapena } \\
\hline$\neg$ 30. or: 13 orrialde zenbakia & \multicolumn{1}{|c|}{ Urkixoko alea } \\
\hline$\neg$ 128. or:: & $\neg 30$ orrialde zenbakia \\
\hline$\neg$ 141. or:: Orrialde zenbakia falta & $\neg$ Cu deia \\
\hline$\neg$ 197. or:: Orrialde zenbakia faita & $\neg 141$ orrialde zenbakia \\
\hline$\neg 215:$ or:: 215 orrialde zenbakia & $\neg 197$ orrialde zenbakia \\
\hline$\neg 227$ or:: Pij zeinadura & $\neg$ Pii zeinadura \\
\hline \hline
\end{tabular}

Vinsonek dioenez, Paul Fauvetek 1700-1736 urte bitartean inprimatu zuen eta 15f, 15h, 15i argitarapenak garai horretakoak dira; ez du uste bere iloba Paul Fauvicik inprimatuak daitezkeenik. Honek 1760-1791 urte bitartean inprimatu zuen, baina bere ezkontzaz gcroztik (1764.ekn ekainaz geroztik) Fauvet-Duhart edo Duhart-Fauvet sinatzen du eta ez, gehiagotan, P. Fauvet. Baliteke Vinsonen ustez hiru hauetakoren bat Pierre Fauvet, Paul Fauvet-Duharten osaba eta Jean Fauveten anaiarena izatea. Honek 1757-1781 urte bitartean izan zuen bere moldiztegia.

Argi utzi nahi genuen lan honen sarreran Julien Vinson izango genuela bibliografiari eskainitako atalaren ardatz eta aurretikako zein ondorengo lanek aukeraketa hori baieztatu eta sendotu besterik ez dute egin. Ikusi dugu Aita Larramendi, Pierquin de Gembloux, Francisque Michel eta L. L. Bonaparte Printzeari bidalitako eskuizkribuak ez digutela, inondik ere, Noelac-en edizio guztien berri eman, eta helburura hurreratu den lehena Julien Vinson izan dela. Bere ondorengo Sorarrain eta Louis Desgravesek, ${ }^{24}$ ordea, ez digute bere

${ }^{24}$ Honen bi lan aiparu nahi genituzke. «Les livres imprimés a Bayomne au XVII" siecle», lehena, etá «Les livres imprimés à Bayonne au XVIII siècle», bigarrena. Bi izenburuok ikusita, gogoz ekin genion irakurketari baina, tamalez, ez genuen ezer berririk aurkitu. Agian, ez dena bilatzen ihardun dugulako. Esaterako, aipatu lehen lanean 1972: 382) Vinsonen bibliografian agertzen diren 15c, 15d eta 15 e argitarapenen berri ematen zaigu, 1697. ekoa lehena eta 1699. ekoak hurrengo biak. Argi uzien du berak ere «d'après Vinson» egin dituela bere aipamenak. Izan ere, transkribaketa hutsen bat salbu, hitzez hitz dagokio Vinsonen azalpenei. «Les livres imprimés à Bayonne au XVIII' siècle) lantxoan (1975: 176), XVIII. mendean Bayonan agertu ziren Noelac-en edizioen 
lanean agertzen ez denik erakusten.

\subsubsection{Zeharkako tradizioa ${ }^{25}$}

Ez gara luzaz mintzatuko zeharkako tradizioz guregana heldu diren Noelacen atalez. ${ }^{26}$ Zerrenda ditzagun, besterik ezean, aurkitu ditugun Noelacen atalak edo bertso sortak:

- Aita Akesoloren Noelacen edizioa, 1907.ean Sociedad Guipuzcoana de Ediciones y Publicaciones, S.A.k plazaratua.

- Aita Larramendiren Artea. Bi bertso sorta: "Innocénten Amen dolorearén gañean Noela" ela "Nolá bátzuc haurrequin ihessi aviatú cirén".

- Euskal-Erria aldizkaria, 1886. Aurreko bertso sorta berbera.

- Gure Herria, 1925. "Artzainak Bethleemen" izenburua duen bertso sorta bat argitaratu zen. Sortaren amaieran Noelacen 1760.eko argitarapenetik hartuak direla dio, 67, 68, 69. orrialdeetatik, ortografia gaurkotuz ezarriak.

Oso interesgarria iruditu zaigu ohar hau, ez baikenekien ikusi ditugun Noelac-en argitirapenetatik bat 1760. urtean koka genezakeenik.

Argitarapen honek $15 i$ ezaugarria du Vinsonen sailkapenean. Ikusi dugu, Noelac-en edizio desburdinen aipamen bibliografikoak egin ditugunean, Vinsonen ustez. 15f, 15h eta I 5 i argitarapenak 1700-1736 urte bitartean imprimatu zuen Paul Fauvetenak direla eta ez bere iloba Paul (1760-1791) edo Pierre Fauvetenak (1757-1781).

Baina Gure Herria aldizkariaren arabera, edizio hau 1760. urtekoa da. Oso datu interesgaria. aurrerantzean kontuan izan beharrekoa.

- Gure Herria, 1926b. Ikusi ditugun Aita Larramendiren bertsoak.

- Gure Herria, 1926a. Bi noela: "Erregueen adorationearen gañean trufaniacols" eta "Innocenten massacraren gañean, Innocenten bestetacotz".

- Gure Herria, 1926c. "Andre Dena Mariaren Eliçan sartcearen gañean Noela Candelerocotz" eta "Jesus Haurra templuan aurkhitcearen gañean Noela".

- Egan, 1995. "Bethleen'en ostaturik ezin aurkhituaren gañean noela".

- Gure Herria, 1929b. P. Argaiñaratsen akrostikoa.

berri aurkituko dugu (Vinsonen 15f, 15g, 15h eta !5i). Kasu honetan ere, Vinsonen lanetik hitzez hitz hartutako datuak.

25 Zeharkako tradizioa diogunean, Alberto Blecuaren hitzak ditugu gogoan (1988, 38): «Un texto ha podido llegar hasta nosotros a través de uno o más testimonios, en tradición directa o en tradición indirecta, es decir en citas de orros autores, fragmentos, en antologias, en refundiciones, en traducciones, etc. y en forma manuscrita o impresa, o en ambas a la vez».

${ }^{26}$ Ikus beza, nahi duenak, honetarako Atutxa 1999, Noelacen zeharkako tradizioari eskainitako atala. Lortu ditugun emaitzak ere ez dira adierazkorrak, aipatzen dugun kasu batean salbu. 
- P. Lafitteren Euscaldunen lorategia-n (1931: 26-27) agertzen diren bertsoak.

- Aita Onaindiaren Mila euskal-olerki eder-en (1954: 199-201) agertzen direnak.

- Kamelo Etxenagusiak bere Iparraldeko Euskal Idazleak liburuan (1981: 61-62) biltzen dituenak.

\subsection{Lekukolasun desberdinen biluzketar?}

\subsubsection{Oinarrizko testuaren aukeraketa}

Lan honetan zehar aipatu dugunez, Noelac-en bederatzi argitarapen desberdin lortu ditugu, oinarrizko testuaren aukeraketaren orduan izan dugularik non aukeratu.

Alde honetatik, argi ikusten da lau hildo desberdin bereiz ditzakegula:

\subsubsection{15b, 15c, 15c-1,15d, 15f eta 15h argitarapenak.}

Talde honetako argitarapenak 22 lerro $^{28}$ dituzte orriaideko, orrialde zenbaki eta zeinadura eta deiak kontuan izan gabe. Talde honetako edizio guztiak, haatik, ez datoz erabat bat. 15b-tik 15c, 15c-1, 15d eta $15 \mathrm{f}$ argitarapenetara, azken hiru orrialdeetan (238240), ${ }^{29}$ lerro bateko aldea dago (azken lau hauetan zazpi lerтo ditugu 240. orrialdean; lartan, sei).

15h argitarapenean, berriz, 210. orrialderaino, 22 lerro ditugu. Hemendik aurrura (liburaren laugarтen ataletik aumera, alegia), 27 lerro izango ditu argitarapen lionek, kitra tipoa txikiagoa delarik.

15b, 15c, 15c-1, 15d eta 15f argitarapenetan, 214. orrialdean hasten da laugarren atala; $15 \mathrm{~h}-\mathrm{k}$, bada, hiru orrialde irabazi ditu liburuko lehen hiru ataletan. Alde hau honako arrazoi hauengatik gertatzen da, izenburu, ahapaldi, e.a.-en artean dauden tarteak edo zuriuneak nabarmenago direlako argitarapen haietan.

$15 \mathrm{f}$ argitarapenak, lan honetan zehar aipatu bezala, aurrekoek ez. dituzten bertso berri eta desberdinak ditu amajeran (241-250 orrialdeak). 15h argitarapenak ere bertso berriak eta desberdinak ditu, baina ez $15 \mathrm{f}$-an agertzen direnak, $15 \mathrm{~g}$ eta $15 \mathrm{i}$-an ditugunak baizik.

Joseba Lakarrari jarraiki (1988b: 124), zera aipa dezakegu: «Benetako edizio kritikoa egiteko lekukotasun guztien biluzketa nahita nahiezkoa du argitaratzaileak, eta hori aurretik edizio kritiko anitz izan arren, usu ez da lan guzri horrekin gehiegi aurreratzen baina oinarrizko araua dugu.»

- Inolako izenbururik, kapitulurik, plekarik edo bestelakorik agertzen ez diren orrialdeak dira kontuan hartu direnak lerroak zenbaizeko. Testu normalez osotutako lerroak, beraz.

Kontuan izan behar dugu 15 b argitarapena ez dela 240. orrialdean amaitzen, jarraian aurkibidea baitator 251 . orrialderaino. 


\subsubsection{2. $15 \mathrm{~g}$ argitarapena.}

Dakigunez, bau da itxuraz. neurri desberdina duen argitarapen bakarra (in-1? itxurakoa, J. Vinsonen arabera), eta nabari da desberdintasun hau orrialdecn e\%arketan cre, edizio honek 26 lerro baititu orrialdeko; lau lerroko aldea, beraz, a) taldeko argitarapenen orrialdeekin.

\subsubsection{15e argitarapena.}

Hau ere desberdina da autekoekin konparatuz gero. Honek 21 lerro ditu orrialdeko. kaxa a) multzokoena baino laburtxuagoa delarik (haiek $91 \mathrm{~mm}$. aituerakoa dute 22 lerrotarako; honek, $89 \mathrm{~mm}$-koa 21 lerrotarako).

Argitarapen honetan ere, 15h-an bezala, letra tipoa aldatu egiten zaigu. Honetan. burriz, liburuaren laugarren atalerik aurera, 220. orrialdetik aurrera alegia (hemendik aurrera, 27 lerro ditugu, letra tipoa askozaz txikiagsoa delarik).

\subsubsection{I 5i argitarapena.}

Hau ere desberdina da aurrekoekin konparatzen badugu. Ilnnek 20 lerro ditu orrialdeko, kaxa a) multzokoena baino laburragoa delarik (haiek $91 \mathrm{~mm}$. altuerakoa dute 22 lerrotarako; honek, 82 mm.-koa 20 lerrotarako).

Argitarapen honetan ere, 15h-an bezala, letra tipoa aldatu egiten zaigu. Honetan, berriz, liburuaren bigarren ataletik aurrera, 106. orrialdetik aurrera alegia (hemendik aurтera, 25 lerro ditugu, letra tipoa askozaz txikiagoa delarik). Edizio honen amaieran. $15 \mathrm{~g}$ eta 15 h edizioetan ditugum bertso berriak ditugu.

Noeluc-en edizio desberdinen orrialdeen ezarketaren aldetiko nabardurak azaldu ondoren, oinarrizko testuaren aukeraketa egitea dagokigu. Aurrerantzean aipatuko ditugun orrialde eta bertso zenbakiak 15b argitarapenari dagozkio (15b diogunean - emandako salbuespenak salbuespen-, 15c, 15c-1, 15d ela 15 f cre esan nahi dugu).

\subsubsection{Orrialde ela lerroen zenbakikuntza}

Sistema bakarra erabili dugu liburuaren orrialdeak eta lerroak zenbatzeko. Honetarako. hiru alde lesberdinetan banatu ditugu lerroak:

- Bertsoak

Hitz-lauz idatzirikoak

- Izenburu eta bestelakoak

Bertsoei zenbaki arabikoak egokitu zaizkie; hitz-lauz idatziriko lerro guztiei ere zenbaki arabikoak egokitu zaizkie. bakoitzaren amaieran lerroa adierazi nahi duen L bat itsatsi ougularik (1 L, 2L, 3L... nL.); aralde, buru, atal, bertso sorta, e.a.-en izenburuei, berriz, 
IZI, IZ2, IZj... İn egokitu zaie.

Bertso eta hitz-lauz idatzirikoen zenbakikuntza lehen orrialdear hasi eta amaierarainokoa izan da; izenburuei dagokienez, berriz, orrialde bakoitzean berriro hasi dugu zenbaketa.

Noelac liburian 4.542 bertso eta hitz-lauz idatziriko $83 \mathrm{~L}$ leпro zenbatu ditugu. Azken hauek onespen, baimen, Ioan Ihartiusen epigrama eta liburuaren parteen azalpenari dagozkio. Tarteka-marteka, zenbait izenburu ere zenbatu ahal izan dugu.

\subsubsection{Aldaeren antolaketa}

Liburuaren lekukotasun desberdinen konparaketak milaka aldaera eragin du. Ezin genituen, haatik, aldaerok inolako antolaketarik gabe eman, orrialde bakoitzean atera ahala zerrenda batean, elkarren segidan, inolako ordenu eta sistematizaziorik gabe. Sistematizazio horren bidean, zenbait iturritan edan nahi izan dugu: batetik, A. Blecuak bere Manual-ean erakusten diguna; bestetik, A. Roncagliarena (Principi, 1975: 96-140) eta azkenik, neurri txikiago batean, Joanes Leizarragaren Testameniu berria-ren edizio kritikoa prestatzerakoan, Th. Linschman eta H. Schuchardt-ek egin duten sailkapena. Azken hau «Sobre el modo de disponer la reimpresión, en particular sobre las erratas $y$ variantes en el texto de Leizarraga); izenburupean jarri duten sarreran aurki genezake (Leizarraga, 1990: 148-180).

\subsubsection{Jarraitutako metodologia}

Blecua, Roncaglia eta Schuchardien hutsen banaketek zera erakusten digute; testu baten transmisio prozesuan (kopiatzea zein kajistaren konposaketa lana izan), lau sai\} nagusi behinizat egin daitezkeela:

\footnotetext{
- gehitzearen ondorio diren aldaerak

- ezabatzearen ondorioz gertatu direnak

- leku aldatzearen ondorio direnak

- ordezkatzez gertatzen direnak
}

Bestalde, kontu garrantzitsu batez ohartu behar dugu: askotan. argitarapen batetik bestera gertatzen diren aldaketak editore edo inpresorearen (ez dut uste kajistaren ausartkeria horrenbesterainokoa izan zitekeenik) parte hartze zuzenaren ondorioz gertatzen direla eta nahita eginikoak direla, aldaketa kontzienteen aurrean aurkitzen garela. Hau argi ikus dezakegu Eliçara erabiliceco liburuaten bigarren edizioan, 1666.ekoan. Ezin dira autore aldaera bezala hartu, ordurako Joanes Etxeberi hila dela suposatu behar dugulako; editore aldaerak edo deitu beharko genituzke, beraz. Eta honetan ere bi hildo bereizi beharko lirateke:

- Grafiari dagozkion parte hartzeak

- Bestelakoak 
Lehenei dagokienez, kontuan izan behar dugu euskararen tradizio idatziaren leben pausuak ematen ari direla eta ez dagoela grafia homogeneotasunik; are, askotan liburuetan agertzen zaigun grafia inpresorearena izaten da eta ez idazleak inposatu duena.

Julien Vinsonek - Axularren Giuero-ren lehen bi edizioen konparaketaz diharduelahomako ohar hauek ematen ditu (1891-8: 88-89):

Dans la première édition, comme je l'ai déjả dit, beaucoup de ç et $n$ tilde sont remplacés par des $e$ à queue et par des fi partiellement rognés, ce qui ne se représente pars dans la seconde édition; des $K$ pet. cap. tiennent la place de $\mathrm{K}$ grandes capitales; la forme de certaines lettres est plus archaïque; on y trouve mème (p. 337) l'abréviation dimittim 9 pour dimittimus (rien de pareil ne s'observe dans la seconde édition; enfin les $a, e, i, 0, u$ tilde pour an, en, in, on, un, sont infiniment plus fréquents. Ces indices d'un archaïsme relatif sont aggravés encore par l'usage constant de $l$ et $V$ pour $J$ et $U$ capitales régulièrement employés dans la seconde édition, ansi que par la confusion des $i$ et des $j$. des $v$ et des $u$ bas-de-casse dans la seconde édition; pour celle-ci, on a adopté partout l'orthographe moderne dans la citations latines: nova, jus, usque, deliciis par example correspondent aux noua, ius, vsque, delicijs de la première édition; mais on n'a presque rien changé sous ce rapport au texte basque que l'imprimeur et ses ouvriers ne comprenaient probablement pas. Or, dans les livres imprimés par J. MongironMillanges, par ses successeurs et par ses confrères de la région, y compris les Fauvet de Bayonne, cette réforme orthographique ne fut complètement adoptée que tout à la fin du XVII' siècle ou au commencement du XVIII'.

Grafia aldaketez landako beste aldaketa kontzienteak ere agertzen dira Eliçara liburuan, batez ere lehen atalean (63 orrialde), denbora eta aro kontuez ari zaigunean (den denak ditugu azalduak zazpigarren kapjiluluan). Horiezaz aparte, hona hiru nabarmen:

\section{6. orrialdean}

b) Iaincoac bada gure bihotçac eta gorputçac guidatçala, Iaincoaren Temearen, eta Chriftorè amorioan, eta iauna çuc içaçu gutças milericordia.

\section{6. orrialdean}

b) Ceren dudan çure legule Saindua mezpreçatu . Ela ceren eguin dudan Haren contra bekhatu.

c) Iaincoac bada gure bihotçac eta gorputçac guida detçala, taincoáren onheriztean, eta Chrifloren patientian, çuc bada iauna gaitutçun vтricäri.

\section{7. orrialdean}

b) Badaquigu galdeguiten Hari diotçotçunac,.

Aithortuac

Bereala ontaflunac.

c) Ceren dudan çure legue Saindua mezpreçatu, Eta haren contra eguin Nauarbenqui bekhatu.

c) Badaquigu galdeguiten

Hari diotçotçunac,

Berehala aithorluac çaizquitçula ontallunac.

Honelako eta bestelako adibide guztiak 3. eranskinean jarri ditugu. 
Argi dago, bada, aldaketa kontzienteen atal berezi bat izan beharko genukeela, bertan grafia kontuak eta bestelakoak agertaraziz.

Hirugarren atal nagusi bat inprentak berak izan zitzakeen arazoei eskainia legoke. Atal honetan sartuko genuke, adibidez. C-C aldaeren kontua. Schuchardtek ere guk geuk izan dugun arazo berbera izan zuen eta Leizaradyar'n Teslamentu berria-n (1982: 141). «A esto se añade también la C. parcialmente equivalente, y por tanto Leizarraga no la incluye en ese lugar. Esta Ç no se encuentra in todos los tipos de letra, y por eso es sustituida o bien por la misma $C$ en otro tipo de letra, o bien por la $C$, que es lo normal, como en iniciales. en titulos, en redonda pequeña.» dio. Askotan gertatu zaigu guri ere edizio batean $C$. eta beste batean $\mathrm{C}$ edo ç aurkitzea.

Aipagarria da, bestalde, puntuazio markei buruzko arazo berezi bat. Hau da, Schuchardten hitzetan, kontu berezi hori (Leizarraga, 1982: 141):

Por lo que hace a los signos de puntuación, no sólo, comn ahora, el punto, sino también los dos puntos, el signo de interrogación y la coma acostumbran a ir pegados justo a la palabra precedente, incluso ante un espacio de línea vacio. No rara vez aparecen apretados entre palabras. Por orra parte, de cuando en cuando están muy espaciados.

Hau ere gertatu zaigusez, atal honetan aztertuko ditugu honen ondorioz sortutako aldaerak.

Kalte materialek ere beraien tartetxoa izango dute.

Aipatu ditugun ohar euztiok kontuan izanik, honako sistema hau proposatzen da Joanes Etxeberriren liburu honen edizio desberdinek eskaini dizkiguten aldaerak sailkatzeko:

1) Aldaketa kontzienteak. Editore edo inpresorearen parte-harze zuzenaren ondorioz gertatutako aldaerak (AK ezaugarriaz aipatuko ditugunak aurrerantzean).

1.1. J:reforma ortugrafiknari dagozkion aldaerak (EO ezaugarria).

DAR (dardarkarien laldea)

RBB ( $r$ bakuna/bikuna ematen da aldaera desherdinetan)

DIP (diptongocn taldea)

. I, EI, OI, UI diptongoak

EK (erdikontsonanteen taldea)

DAK (diptongoa apurtzen duen kontsonantea bai/ez)

JIK (j-ren ingurune fonetikoa)

$\mathrm{G} / \mathrm{GU}$ (g/gu taldea)

GUA, GUO

LEH (leherkarien taldea)

SUD (sudurkarien taldea)

TXA (txistukari afrikatuen taldea)

TXI (txistukari frikarien taldea) 
URK (urkarien) taldea)

$\mathrm{U} / \mathrm{V}$

1.2. Bestelakoak (BES ezaugarria).

Mm (maiuskula/minuskula taidea)

2) Transmisio prozesuan gertatutako hutsak. Gehienetan, kajistari egotz lekizkiokeen hutsen ondoriozko aldaketak (HU ezaugarriaz ezagutuko ditugunak).

2. 1. Argitarapen batetik bestera, zerbaiten gehitzea izan da: adiccrio (ADI ezaugarria).

AHS (amaieran hizkia soberan dago aldaera batean)

BHS (barnean hizkia soberan dago)

HHS (hasieran hizkia soberan dago)

HOS (hitz osoa dago soberan)

2.2. Argitarapen batetik bestera, zerbait ezabatu da: detraclatio (DET ezaugarria).
AHH (amaieran hizkia falta da aldaera batean)
BHF (barnean hizkia falta da)
HHF (hasieran hizkia falta da)
HOF (hitz. osoa falta da)
LOF (lerro osoa falta)

2.3. Argitarapen batetik bestera, leku aldatze bat dugu: ransmuratio (TRA ezaugarria).

ME: I'A (hizkien arteko metatesia)

$\mathrm{HBB}$ (hizkien arteko metatesia)

LBB (lerroen arteko metatesia)

2.4. Argitarapen batetik bestera, ordezkatze bat gertatzen da: immutalio (INM ezaugarria).

BER (Bersalita/maiuskula-minuskula taldea)

HBB (hizki bat edo beste ageri dira aldaera desberdinetan)

HTE (hitza bera txarto ebakia ageri da aldaeraren batean)

$A A B$ (aditz partizipioa/laguntzailea banatuak bai/ez)

$\mathrm{HAB}$ (hilza itzizkia banatuak bai/ez)

HAH (hit cn arteko hutsunea bai/ez)

HBB (hiiza bera banatua argertzen da)

2.5. Puntuazio markak (PM ezaugaria). 
BPAH (bi puntu aurrean hutsunea bai/ez)

BPOH (bi puntu ondoren hutsunea bai'e?)

BPBE (bi puntu bai/ez)

DIERE (aldaeren hizkiren batean dieresia bai/ez)

GIAH (galdera ikumaren aurrean hutsurea bai/ez)

GIHI (cialdera ikurra/harridura ikurra)

GIBE (galdera ikurra bai/ez)

HIBE (haridura ikura bai/ez)

$\mathrm{KAH}$ (aldaeraren batean hutsunea koma aurrear)

KBE (koma bai/ez)

KBP (koma/bi puntu)

KGI (koma/galdera ikurra)

KHI (koma/harridura ikurra)

$\mathrm{KOH}$ (koma ondoren hutsunea bai/ez)

KPK (koma/puntu eta koma)

$\mathrm{K}$ - (koma/marratxoa)

PAH (puntu aurrean hutsunea bai/ez)

PHI (puntua/harridura ikura)

PBB (puntu bat/bi)

PBE (puntua agertzen da bai/ez)

PBP (puntua/bi puntu)

PGI (puntua/galdera ikurra)

PK (puntua/koma)

PKBP (puntua eta koma/bi puntu)

PKGI (puntua eta koma/gaidera ikurra)

POH (puntu ondoren lyutsunea bai/ez)

PPK (punlua/puntu eta koma)

-BE (marratxoa bai/ez)

3) Inprenta arazoak (IA ezaugarria).

HM (hitz bat mugitu egin da bere berezko tokitik)

LBB (kaxa luzeago/laburrago aukeratzearen ondorioz, hitz bat lerro bat/bitan)

$\mathrm{M} / \mathrm{VIR}$ ('n' hizkiaren ordez virgula jarri denean)

N/VIR ('n' hizkiaren ordez virgula jarri denean)

OBB (orrialde batean',hestean daude zenbait bertso)

OF (orrialdeak falta diri)

TIP (tipo desberdinak edizio batetik bestera)

$\mathrm{ZED}(\mathrm{C} / \mathrm{C} / \mathrm{c}$ dugu edizio desberdinetan)

4) Kalte materialak (KM ezaugarria)

HF (hizki bat falta da aldaeraren batean)

AHF (amaieran hizkia falta da)

BHF (hitz barnean falta da hizkia) 


\section{HHF (hasieran hizkia falta da)}

Azkenik, lortu ditugun emaitzak ematea genuke.

Bestalde, aintzat hartu beharreko kontu batez ohartu nahi dugu irakurlea; testuaren toki jakin batean, lekukotasunek irakurketa desberdinak dituztela: A eta honen aurrean $B D C$, edo $A B$ eta $C D$, edo $A B C$ eta $D$, e.a. Noski, obra baten bi lekukotasun baizik ez badugu, kontua oso sinplea da, A izango dugu Bren aurrean, eta akabo. Arazoa, zailtasunak, harretaz ibili beharrak, lekukotasun asko dugunean sortzen dira.

Joanes Etxeberiren obren kasuan, bi hildoak ematen dira: Mamual devohionezcoa eta Eliçara erabiliceco liburua obren bi lekukotasun heldu dira gure eskuetara, 1627 eta 1669.ekoak hartan eta 1665 eta 1666.ekoak honetan. Noelac obran, aldiz, bederatzi lekukotasun desberdin. Lehen bi obren lekukotasun desberdinek eragin dituzten aldaeren zerrendak ezin dira zehatzago bihurtu alde honetatik; bai, ordea, Noelacen lekukotasunek eragin dutena. Eta horixe da, hain zuzen ere, jarraiko orrialdeotan aurkezten duguna. Aldaeren zerrenda hura hátu eta irakurketa desberdinak taldeka banatu ditugu: toki jakin batzuetan B lekukotasunaren irakurketa gainontzeko guztien aurrean agertzen bada, aldaera guzti horiek multzo batean; GHI lekukotasunenak gainontzekoen aurrean baditugu, beste multzo bat, eta horrela konbinaketa guztiak agortuz.

Zeregin honek jarraiko ataleko lekukotasun desberdinen azterketa eta aukeraketa, batetik, eta stemmaren eraikuntza, bestetik, erraztuko dizkigu.

\subsection{Stemmatica}

Testu luze baten kopian batrena gurtatzen diren eratorpen eta loturen harremanen erakuspen (errepresentazio) eskematikoa izendatzen dugu stemma hitzaz: harremanok kopiaren beraren azterketaren bidez edo bere komunztadura eta ezberdintasunetan ezagut genitzake. Siemma era ziur batean hala ezagututako hutsak oinarri hartuta berreraikitzen da. eta gero eskuskribu desberdinetan aldaera adiaforak -hau da, irakurketa desberdinak baina maila berean onesgarriak direnak- kontrajartzen direnean, haulaketa bideratu eta justifikatzeko erabiliko da. Funtzio praktiko honezaz gain, stemmak esangura historikoa du: era erraztu batez, testua trasmititu den gorabehera historikoaren erro esentziala erakusten baitu.

Edozein istripu materialen (lohidura, zulo, ebaki edo antzekoak) ondorioz, testu atal bat irakurgaitz izan bada ale honen, eta honenak bakarrik, eratorri diren kopia guztiek dagokien hutsunea (edo hutsuneari dagokion tokian jarri den berrikuntza konpontzailea) izango dute. Hutsune hauen presentzia zilegiro jasoa izan daiteke ahaideria froga bezala, hau da. materialki gertatu den istripuak eragindako hutsune hori jasan duen ale bakarrari

${ }^{30}$ Etxeberriren hiru liburu inprimatuen lekukotasun desberdinen biluzketak eragindako aldaeren zerrenden berri nahi duenak jo beza Joannes Ercheberri Ziburukoa. Obraren berrirakurketa bibliografikoa era testu kritika lanera (Atutxa 1999). 
dagokionez, hutsune berdina agertzen den kopia guztien eratorpen froga bezala. Lotura honek, noski, bere balioa galduko du jatorrizko istripuko alea gorde ez den heinean: baliteke istripua isladatzen den kopia guztietako iturri beraren existentzia momentu batean materialki frogatua ez etortzea, baina arrazonamenduz postulalu beharko da.

Arrazonamendu berdintsua errepikatu ahalko da tradizioan zehar gertatutako edozein ustelkeriarako, mekanikoa ezbada ere. Hau izaera probabilistikodun aitzinasmo batean oinarritzen da. estadistikoki froga daitekeena: hipotesirik ekonomikoena izaten da, oro har, frogagarriena. Izan ere kalte batek testu berbereko kopia desberdinetako leku berberean erasotzeko probabilitatea nunimoa da. Aiderantziz, zenbat eta testu berbereko kopia gehiagok ustelkeria berbera erakutsi toki jakin batean, orduan eta arrazonamendu handiagoz azalduko da oinarrizko ale bereko kopien ondorengotza bateratua (amankomuna), eta arrazoizko azalpen hau zenbat eta hála beharrezko kointzidentzia ez dela egitxurakoagoa izan, orduan eta frogagarriago gertatuko da.

Argi dago, berez, irakurketa batean ematen den kopia bi edo gehiagoren komunztadurak beste baten aurrean ez dituelá ahaideria interferentziak baimentzen irakurketa hura okerrekoa dela erakutsi bitartean. Egia da, autore aldaeretan salbu, bi irakurketa (edo gehiago) alternatiboren artean bat bakarrik izan daiteela benetakoa. Baina berez ulergarria den edozein irakurketa egiazkotzat uste ukan dezakegu eta, ondorioz, lehiakideen parean, berreraiketa geneaologikorako baliogabekotzat har dezakcgu faltsua dela identifikatu arte. Aldaera adiaforak erabiltezinak dira stemmeren berreraiketarako.

Noski, butsa zenbat eta hutsalagoa izan, orduan eta handiagoa izango da huts amankonun bat itumi amankomun baten menpean egoteko probabilitatea, orduan eta ziurragoa ahaideria lotura. Ahaideria frogatzeko baliogarritzat hartua izan dadin, knintzidentzia poligenetiko baten hipotesia arrazonamenduz ezabatzen uzteko besteko izaerakoa izan beharko du huts batek. Bi eskuskribu edo gehiagoren ahaideria baieztatzeko. nahikoa da beraien artean gutxienez huts amankomun baten presentzia egiaztatzea.

Bitartean, noski, kopia bi edo gehiagorekiko huts amankomunak zenbat eta ugariago izan, orduan eta indartuago gertatuko da ahaideria lotura objektibo baten probabilitatea. Huts hutsál batean eman daitekeen kointzidentzia ezin daiteke teorikoki gertagaitzat aldidrrikatu, erabat gertagaitza bada ere. Eraiketa stemmatiko baten sendartasuna, bada, testu bainn konia desberdinak «familiatan» biltzen lagunduko diguten hutsen pisua eta kopuruarın araberakoa izango da.

Huts baten presentzia ezagutzea, huts horren pisua adierazgarri bezala baloratzea, judizio egintzak dira, interpretazioari hertsiki lotuak. Hitz batean, stemmatika ere interpretazioan oinarritzen da, edozein operazio filologikotan une esentzial ezin besteko bezala baieztatzen delarik. Stemmak ziurtasun matematikoa ematen dio zenbait hautaketari (aldaera adiaforen artean), baina ezin da berreraiki kontsidero ez matematikoak alde batera utzirik.

3.3.1. Aldaerak 
Aldaeren azterketarekin lekukotasunen jatorria zehaztu nahi da. Honetarako, metodo logiko bakarra honakoa da, huts amankomunak baizik erabiltzen ez dituena lekukotasunen jatoria zehazteko.

\subsubsection{Huts amankomunak}

Derragun, laburbilduz, lekukotasunen jatomia zehazteko, erizpide eraginkor bakarra huts amankomunean oinarritzen dena dela. Argi dago huts batean batera datozen bi lekukotasun, azken instantzian huts hori zegoen eredu amankomun batera joango direla.

Izan ere, testu kritikaren operaziorik delikatuena huts amankomunaren ezartera zuzenean datza; eta kontu handia izan behar da bi lekukotasun edo gehiagok egin dezaketen huts guztiak ez baitoaz agertzen ziren eredura. Bi kopista edo gehiago huts berean, hala beharrez, batera etor daitezke, kopia operazio beraren hutsak direlako: haplografia. ditografia, berdinen arteko jauzia, lectio facilior, huts paleografikoa, e.a. Kasu honetan, bada, ustegabcko huts lokabeak dira, huts poligenetikoak, jatorria zehazteko balio ez dutenak. Iluts amankomuna, bada, bi lekukotasun edo gehiagok beraiengandik at ezin egin izan dutena da. Komenigarria da, haatik, huts amankomun bateratzaile eta huts amankomun banatzaileak desberdintzea.

\subsection{Huts bateratzaileak}

Huts bateratzaileak, bi kopia edo gehiagorekiko anankomunak izanik (eta kopista desberdinek bata besteagandik at egitea gertagaitzat edukitzeko izaerakoak), kopia hauen arteko konexio froga bezala zilegiro hartuak izateko aukera ematen duten hutsak dira. Konexioa era desberdinetan azal daiteke. Kasurik sinpleenean, huts bateratzaileez elkattutalin bi lekukotasun A eta Btik, hiru hipotesi dira, izan, posibleak: I) B Atik eratorria dela, II) A Btik eratorria dela, III) A eta B, bi lekukotasunak, x iturri amankomun batcrik eratorriak direla; honela jarraiko oinarizko stemmak dira posible:
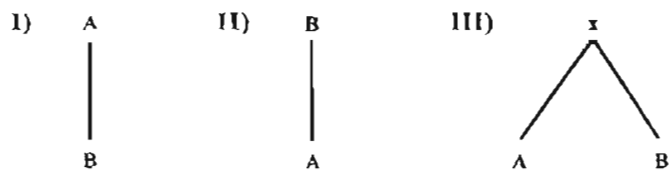

B Atik eratorria dela baieztatu ahal izateko zera gertatu beharko da, Bk Ak dituen huts gurtiak aurkezten dituela eta, gainera, bere berezko hutsen bat. Era beretsuan, A Btik Iittoria dela baieztatu ahal izateko $1 \mathrm{k}$ Btik huls gurijak aurkc\%lu beharko ditu eta, gainera, buru bere\%on huticn bat. Lekukotasun bat bestearen eratorria dela baztertu ahal izateko zera gertatuko da, Ak Bn ez dauden hutsak aurkezten dituela eta, ordairizka, Bk An ez daudenak: huts amankomunez landa, kopia bakoitzak bere berezko hutsak aurkezten dituela. 


\subsection{Huts banatzaileak}

Huts banatzaileak, kopia batean bai eta bestean agertzen ez direlarik, lehenaren besteekiko independentria trogatzen uzten diguten hutsak dira. Huts bati balio banatzailea iratxeki ahal izateko baldint a bat honakoa da, aicruz erracki zuzendua iz izateko besteko izacrakoa izatea eta, bestalde, bere ausentziak agertzen den likukotasunetatik independientea dela erakutsi behar duen lekukotasunetan aieru bidez ezabatua izateko susmorik agertu ezina.

Argi dago baldintza hau eta huts bateratzaileen balioa zehazten zuen hura desberdinak direla. Huts bateratzaileek konexio harremana erakusten dute; garrantzitsua dena zera da. lekukotasun bat baino gehiagotan inolako lokarririk gabe sortu direla suposatu ahal izatekotan, beraiek hain errazki ekoizgarriak ez izatea. Huts banaizaileek, ordea. menpekotasun harremana baztertzen dute: garrantzitsua dena zera da, bere iturrian aurkituko lukeen lekukotasun batetatik aieruz ezabatua suposatu ahal izatekotan, hain erraz zuzenduak ez izatea. Beraz, zera ulertu behar da, aieruz zuzendu eta ezabatuak izateko errazlasun hori kasuz kasu baloratua izan behar dela, ez bakarrik hutsen funtsezko kalitateari dagokionez, baita aztertzen ari garen lekukotasunen artean igarotako tartean kopisten testu kritika gaitasunari eta kulturaren baldintza orokorrei dagokjenez ere: balorazio horek zera dakar, judizio bikoitza, ulertzekoa eta historikoa, huts bateratzaileak ezagutu eta baliokidetzeko behar direnak baina oraindik delikatuagoa.

Huts bera, beraz, bi ikuspuntuetatik kontsideratua izan daiteke: bateratzaile bezala zenbait eskuskriburi dagokionez eta banatzaile bezala beste batzuri dagokionez. Baina balio baldintza desberdinetarako, huts guztjek, bateratzailetzat kontuan hartzeko dituzten baldintzak izanik ere, ez dituzte, gainera, banatzailetzat hartzekoak izaten, lekukotasun multzo biren artean balio banatzailea onesten zaien hutsei, oro har: dakaren multzoarekiko balio bateratzailea ere ones dakiekeen bitartean. Laburbilduz, hutsalak ez diren hutsak errezago zuzenduak gerta daitezke, zuzentzen zailak diren hutsak hutsalak gerta daitezkeen bitartean.

\subsubsection{Hutsa Noelac liburuan}

Etxebcrriren liburı inprimatuetan, hau da lekukotasun gehien ezagutu duena eta bertan huts amankomun bateratzaile eta banatzailetzat har genezakeen asko dugu. Aurkezlu eta behar dituzten azalpenez horrituko ditugu:

\section{- 010 orrialdea $\quad 1 \mathrm{Z} 2$ bertso zenbakia}

Stephanus de Hirigoiti Doctor Medicus 
Apoltoluec Iefus Chriltoz / generalqui erranen / gañean

Abendocotz Noela

B

Abendocotz $\oslash$

Gainontzekoak

\section{- 040 orrialdea 0539 bertso zenbakia}

Elizabeth cufiñaren / Egotu cen etchean, /

laun doni Iauni Cemeaz / Erdi cedin artean .

Erdi cenean, Virgina/Bihurtu cen etchera,

Bera ere hurbiltcen cen / Erdiceco epphera

B

Gainontzekoak

\section{- 064 orrialdea $\quad 1.016$ bertso zenbakia}

Sorthu cen heia charrera / Cirenean hurbilldu. Errefpetu handiz ciren / Berehala ichildu

$\mathrm{B}$

Berchela
CCIDEF

$\mathrm{GHI}$

B lekukotasunean 'e' horrek oso finak ditu marrak eta posiblea da C lekukotasunaren konposatzaileak 'Berehala' hitzareı bigarren bokalaren ordez 'c' hat irakurri eta, lectio facilior bat dela medio, 'Berchela' komposatu izana. Argi dago, gero. GHI-k 'Berchela' horretatik 'Bercela' zuzentzen dutela. Adibide askotan gertatzen da kontu bera, aipatu dugunez, huts bera bi ikuspuntulatik kontsideratua izan daitekeela, bateratzaile bezala edizio batzuri dagokionez eta banatzaile bezala beste batzui dagokionez. Hemen. esaterako, 'Berchela' huts banatzailea da B edizioarekiko baina, aldi berean, bateratzaile bezala kontsidera daiteke CC1DEF aintzat hartzen baditugu.

\section{- 074 orrialdea $\quad 1.216$ bertso zenbakia}

Mirrhaz, nic ezagutcen dut / Ecen hillen çarela.

Nic berriz urreaz, ecen / Çu erreguela çarela

B

erregue

CCIDFGHI

erreguez

E

Uste dugu argi dagoela irakurketa zuzena 'erregue' dela. Hau egiaztatzeko bertsoen neurria jarri ahalko genuke aitzakia, baina Etxeberriren bertsogintza, bertsoari neurri egokia eman asmoz, gehiketa ugariz dago hornitua (gogoratu Oihenartek egotzi zizkion erruak). Gure ustez errezago azaltzen da kontua beste modu honetara: jarraiko hitzaren bi azken letrek eragindako duplografia arrunt baten aurrean gaude.

- 109 orrialdea

$1 Z 2$ bertso zenbakia

PaQTione fainduaren gañean / canta afte fainducolz

B

Sainduan

Gainontzekoak 
Iuduec eçarti çuten / Sepulturan guardia, Dilcipuluec gauaz altcha/Etceçaten lohia.

B

alto

Gainontzekoak

- 120 orrialdea 2133 bertso xenbakia

Matutiña gau erditfu / Inguruan hartua, B Gautiña gau erditlu / Buthi haren hartua. Gainontzekoak Aitaren çuhurtcia, eta / Eguia eçagutua.

Lehen bertsioa da zuzena, hala agertzen baita Manual devolionezcoa eta Eliçara liburuetan ere.

\section{- 161 orrialdea 2.943 bertso zenbakia}

O lanhari indarlua, / Arren ene bicia, Hagoan iduqui çaçu / Goça artean gloria B Gogoan Gainontzekoak

Jarraiko lerroko lehen bi letren ondorioz. zalantzarik gabe.

\section{- 169 orrialdea $\quad 3.118$ bertso zcubakia}

Onac ioan dire canta / Eta erefielan

B crepiqueta Gainontzekoak

Gaixtoac berriz marrafca, / Eta auhen triftetan

Argi dago, kasu honetan, lehen irakurketa 'eresietan' dela zuzena eta ez gainontzekoek dakartena. Lino Akesolok (1970: 129) 'errepiquetan' erakusten digu, baina bertsoaren ariak, zentzuak, berak obesten du 'eresietan'. Orotariko Euskal Hiztegian (Euskaltzaindia: 1992: 20) ere azaltzen da 'eresi' hitza eta bertan adierazten denez: «Etcheberti de Ziburu lo emplea con el sentido de 'canción', 'himno'...».

\section{- 180 orrialdea $\quad 3.321$ bertso zenbakia}

B lekukotasuna

Iongoico bakhotcha çure

Cantatcen tut orenac,

Arren entçun tçatçu ceure

Laudorio çucenac.
Gainontzekoak

Iongoico bakhotcha

Cantatcen tut çure orenac,

Arren entçun tçatçu ceure

Laudorio çucenac.

Argi dago bertsoen neurriak B bidea eskatzen duela. 
- 185 orrialdea 3.416 berlso zenbakia

Orciralean cinduen / Creatu hegatztiñac

Eta iguericalari / Arrunac han formatu

B

fortu

Gainontzekoak

- 195 orrialdea $\quad 3.597$ bertso zenbakia

Guztiz efiatu cinen / Obran atheratcera, B quezchatu Gainontzekoak

Exemplu on emateco / Infidelen artera

\section{- 217 orrialdea}

\subsection{5 bertso zenbakia}

Virgina ama egotu cen / Çure amaren aldean, Haric eta çutçaz vngui / Erdi cedin artean

B $\theta$

Ciainontzekoak

\section{- 230 orrialdea $\quad 4.317$ bertso zenbakia}

Berehala guero çacu / Çar bat cinduen iauntci B ceure Gainontzekoak

Ela focca pufca batez / Ceure guerrian herti

Hamabost adibideok argi erakusten dute huts banatzaileen aurrean (beti ere egin dugun oharra eginda) gaudela eta B irakurtzen duen bat, bakarra, dela. Gainontzekoek bakar hori irakurri behar izan dute. Hori horrela izan ez balitz, guztietako batek edo zenbaitzuek B zuzenean irakurri izan balute, posiblea zitekeen hamabost locus criticus desberdin hauetako batean edo gehiagotan Bren irakurketa berbera agertzea; baina ez, den denak dakartzate irakurketa berberak. Honek argi ematen digu jarraiko bide hau:

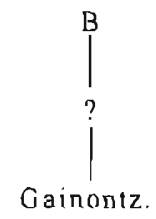

Jarraiko adibideekin, gai izan beharko genuke ? hori zein ediziori dagokion azaltzeko. Edizioak inprimatu ziren urtea kontuan izaki (edo inprenta oinean agertzen den data, behintzat), edizio hori $15 \mathrm{c}$ dela esan beharko genuke, 1697. urtean argitaratua. Baina ikusi dugu lan honelan zehar urte horretako bi edizio ditugula, guk $15 \mathrm{c}$ eta $15 \mathrm{cl}$ izendatu ditugunak eta kontua zeinek irakurzen duen zein erabakitzea izango da, Etxeberriren obraren aurkezpena egin dugunean eritziren bat edo beste emana badugu ere.

Jarrai dezagun adibideokin: 


\subsection{2 bertso zenbakia}

Gurutcearen cantatu / Gogo ditut orenac,

Ielus Chrifto, entçuntçatçu / Ene trifte auhenac

Eta dietçaquidatçu / Barkha neure hobenac,

Dignequiago detçadan / Aippha haren omenac

Banha

Barkha:

B

CCIDEGHI

$\mathrm{F}$

Dirudienez, bada: Fren ondorengnck ez dute F jarraitu, bestela 'Barkha' izan baitzitekeen irakurketa ez 'Banha'.

Argi dago, bestalde, hemen ere huts banatzaile baten aurean gaudela, B eta jarraiko edizioa banatzen dituen hutsa. Noski, 'Banha' hori huts bateratzailea litzateke CCIDEGHI aintzat hartzen baditugu.

\section{- 134 orrialdea 2415 bertso zenbakia}

B lekukotasuna

Aguertu citçaicn ere Guztiei azkenean. Iuduen beldurrez lala Ceudecela batean.
CD lekukotasunak

Aguertu citçaien ere Guztiei azkenean, Iucluen beldurrez Ceudecela fala batean.

\section{CIEFGHI}

Aguertu cilçajen ere Guztiei azkenean, Iuduen beldurrez

Ceudecela batean.

Argi dago, gurc ustez, lekukotasun berriagoen irakurketa lectio facilior bati egotz dakiokeela. Noelacen edizio desberdinen aurkezpena egiterakoan, bestalde, $15 \mathrm{c}$ eta $15 \mathrm{c}$ ! izendatu genituen bezala izendatzearen arrazoiak eman genituen (grafia kontuak, e.a.). Adibide honek coin genuen kronologia baieztatzen du: $\mathrm{C} 1$ edizioa izan balitz B irakurtzen duena, eman zitekeen ematen den emaitza, 'sala' hori desagertzea. Baina Ck Cl irakurri izan balu, zailagoa da ayertzen ez den 'sala' hat gehitzea, aienız zuzentzea. Errezagoa, probableagoa da Clek edo talde horretako batek C' edo D irakurri eta 'sala' ahanztea.

Beste kontu bat ere argi dago, orduan, B irakurtzen duen edizio bakar hori i 5 c edo $15 \mathrm{~d}$ direla (inprenta oineko dataren arabera, $15 \mathrm{c}$ litzateke). Eta $\mathrm{C}$ edo D hori irakurriko lukete gainontzekouk.

\section{- 170 orrialdea $\quad$ IZ1 bertso zenbakia}

Saindu guztiei othoitça / Amurụ Sainducotz

Saindu guztiei othoitç vmea / Saindrucotz

Saindu guztiei othoitç umea / Saindrucotz

Saindu guztjei olhoit çumea / Saindrucotz 
Hemen ere, argi ikus dezakegu B batek baizik è duela irakurtzen (lectio facilior baten eraginez dugu dugun aldaera) eta gainontzeko guztien aldaera $\mathrm{B}$ irakurri duen horretara baizik ez doala. ez Braino. Berriro ere $\mathrm{CD}$ alde batetik eta $\mathrm{ClE}$ bestetik, grafia kontuan baizik cz bada ere. I'k bcre bidea hartzen du eta GHIk beraiena. GHIk dakartena, esaterako, huts bateratzailea litzateke hiru ediziook kontuan hartuta. Argi dago, bestalde 'othoitç umea' huts banatzailea dela Brekiko.

\section{- 226 orrialdea $\quad 4.234$ bertso zenbakia}

B lekukotasuna

longoicoac nahi içan

Cuen azken fiñean

Hequin ohorca aguer

Cedin gente artean.

\section{CIEFH ${ }^{32} I$}

Iongoicoac nahi içan

Çuen azkenenean

Hequin ohorea aguer

Cedin gente artean.
CD lekukotasunak

Iongoicoa nahı içan

Çuen azkennean

Hequin ohorea aguer

Cedin gente artean.

G lekukotasuna

Iongoicoa nahi içân

çuen azkenençat

Hequin ohorea aguer

Cedin gente artean.

1) Kasu honetan ere lectio fucilior baten aurean gaude. 'fi' horrek 'õ' ematen duencz. logikoa da CDk 'azken fiñean' > 'azkennean' irakurri izana, 'azkenñ̃̃ean' posible ez zela pentsaturik.

2) Cl eta gainontzekoek 'mu' bien artean bokale bat sartzen dute, 'azkennean' > 'azkenenean' (alderantzizko kasua ez litzateke posiblea: 'azkenenean' jrakurri eta 'azkennean' ematea); akaso CDk 'azkenean' izan balute, pentsa zitekeen Cl irakurri eta duplografia baten aurrean zeudela konturatuz, 'ne' kenduko zutela, baina honela ez.

3) Hn 'azkenenean' dugu eta Gn 'azkenençat'. Hk G jarraitu izan balu, 'azkenençat'etik 'azkenenean' irakurtzea zaila da. Gk H jarraituz, aldiz, logikoa da gertatzen den aldaera, oinoharrean eman dugun arrazoia dela medio.

4) Ik ere 'azkenenean' irakurizen du.

32 Edizio honetako azken 'e'ak ia 'c' ematen du, hau da 'azkenencat'. Hori horrela izanik, Gk H irakurri an zuela suposatuz gero, logikoa da Gren irakurketa 'azkenençat', egin duen gauza bakarra zera baita, 'c' hori ' bihurtu, behar bezala. 
Ikus dezagun adibide hau:

B) Bere luperbiac çuen

Allabañan erretcen. Handigoaz berce deuÏc

Ez baitçuen penfatcen.

CD) Bere fuperbia: çucı Allabañan erretcen.

Handigoaz berce deulic

Gainontz.) Bere fuperbiac çuen

baiţ̧uen penfatcen.

Allabañan erretcen,

Handigoaz berce deû́c

Bailçuen penfatcen.

Hau, izan, kalte material batck eragin unen hutsa da gure ustez, baina interesgarri bihurtzen du jarraiko kontuak: Argi dago CK B irakurri eta, 'Ez' nonbait galdua, hutsunea mantentzea erabaki duela. C1k C irakurri duenean, ordea, 'baitçuen' hori zuzendu eta maiuskulaz jarri du aurreko hiru beitsoetara lerrokatua.

Kontu hauen aurrean zilegi dirudi honakoa:

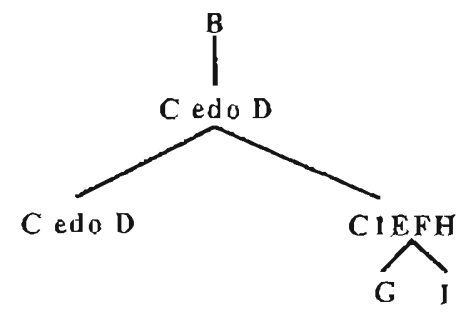

Puntu honetara heiduta, interesgarria litzateke CDri burwzko lerro batzuetan luzatzea.

Biak dira tipografikoki berdintsuak, ia berdinak esango genuke. Eta beraien artean ez dago huts amankomun banatzailerik; ez behintzat zeinek zein jarraitzen duen adierażeko bestekoak. Aztarnaren bat edo beste badugu, ordea, eta horietara joko dugu:

Lehena eta garrantzitsuena, gure ustez. inprenta oineko datarena da. Ck «Baionan, Maffre Baitan, bors / Cantognetan. 1697» dakar; Dk, ordea, «Baionan, Maffre Baitan bors / Cantognetan. 1699). Datok zuzenak badira, argia da Dk C irakurri duela.

Bi edizio desberdinen aurrean gaudela argi erakusten dute bi ediziootako 9 . orrialdeko montaia honek: 


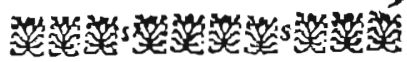
I OANNES ETCHEZERRI
Dotor Tbeologe libura bHnen
egullearibere advquideac
lasdoriozio copla.

$\mathbb{N}_{\text {dur }}^{\text {Icebebintcat aithortce }}$

Cure gordun garela,

Gure Illhumberic libenececo

Cucia gh garela.

Cabarthrio cioana

Efcara crovtcera,

Eecheberrian farthuric

Berrix doa fortcera. Erdaldinac abal doazque,

$C$ ein bere berritara

Gogat eguinic, galdico

Ezimecla Efeara.

Afpoldion cegoena

Gultienscyat azpico

Escheberric als cloabaric

15 c edizioa

\section{0.}
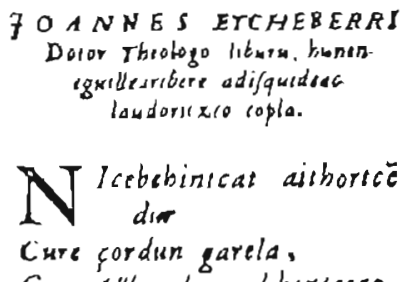

Gure luhumberic lebenicece

Cacio gu farela.

Caburiaric cioana

Efcara croricera,

Eicbiberrian fariburic

U. erriz doa foricera.

Erdaldrnac atal doazgat,

Ceilibere berritara,

Gogat guinic, galduco

Exisurla Efcara.

Afpaldion crgand

(juzromicat azpico

Esciebritis ale chaskrid.

15d edizioa

Hona alderik nabarienak:

- Pleka bera desberdina da edizio batean eta bestean.

$\begin{array}{rll}\text { - 1. lerroan: } & \text { IOANNES } & \text { JOANNES } \\ & \text { ETCHEBERRI } & \text { ETCHEBERRI } \\ \text { 7. lerroan: } & \text { Gure } & \text { Gure } \\ \text { 12. lerroan: } & \text { Berriz } & \text { Burriz } \\ \text { 18. lerroan: } & \text { Guztientçat } & \text { Guztienţ̧as } \\ & \text { azpico } & \text { azpico } \\ \text { 19. lerroan: } & \text { Etcheberric } & \text { Etcheberric }\end{array}$

Honelako aldaketak ugariak dira testu osoan zehar, bi edizioren aurrean aurkitzen garela aitortzeko adineko aldaketak.

Bigarren aztama grafiarena litzateke: B eta C dira grafia arkaikoena darabilten lekukotasunak. $\mathrm{Cl}$ da argien aldentzen dena bi lekukotasunotatik (gero ondorengoak) baina Dn ere ikus daiteke grafia aldaketa honen zertzeladarik. Argi dago, gure uste'z, C 
lekukotasunan 'IAVNARI', deuotionean', 'VRTHVBIE', 'IOAN', 'HVNEN', 'captiuo' eta 'Ivdearen' gisako adibideak izan eta Dn 'IAUNAR', devotionean', 'URTHUBIE', 'JOAN', 'HUNEN', 'captivo' eta 'Iudearen' agertuz, D beranduagokoa dela C baino; beraz, Dk C irakurtzen duela eta ez alderantziz, nahiz eta, gehienetan, grafia berbera izan bi lekukotasunetan.

Diogunez, bada, ez dugu batek bestea irakurtzen duela baieztatzen laguntzen digun huts amankomun banatzailerik aurkitu, baina aipatu kontuon aunean zilegi dirudi DK C irakurtzen duela aitortzea.

Jarraikoak huts amankomun bateratzaileen adjbide argiak dira, gure ustez, hasiera batean eredua irakurri duen edizioak ( $\mathrm{Cl}$ kronologikoki) egin duen irakurketa duplografia edo lectio facilior baten ondorio izan daitekeen aren:

\section{- 056 orrialdea $\quad 0840$ bertso zenbakia}

Bere cerbitço humilta / Cioten prefentatu,

Eta hunela citçaizcon / Bihotz batez mintçatu BCD

$\begin{array}{ll}\text { maintçatı } & \text { ClEFGH } \\ \text { mai tçatu } & \text { I }\end{array}$

Argi dago letra baten gehiketa dugula hemen, 'a' letra, eta hau jarraiko silaban dagoenaren eraginez. Baina duplografia hau gainerako sej edizioetan ere agertzen da, ez honetan bakarrik.

\section{- 062 orrialdea 0976 bertso zenbakia}

Arren bada Yainco guiçon / Gure gatic forthua

Valia dieçą̧uçu / Ceure fortce faindua

$\mathrm{BCD}$

Geure

Gainontzekoak

\section{- 101 orrialdea IZ9 bertso zenbakia}

Iefus Chrifloren Hierufalamera fartceraren gañean ...

fortcearen
$\mathrm{BCD}$

Gainontzekoak

Bi adibide hauetan C/G cla AO letra aldaketa dugu eta, printzipioz, arrunta gerta daitekeen arren, hitzaren esanahia guztiz aldatzen da eta sei ediziok hartzen du aldaera. Noski, zuzena BCDren irakurketa da.

\section{- 207 arrialdea 3845 bertso zenbakia}

Barur egunac cintuen / Beguiratcen lainduqui

$\mathrm{BCD}$ eguinac

Gainontzekoak

Aufteritatez gorputça / Gaztigatcen gogorqui. 
- 238 orrialdea

4470 bertso zenbakia

Halli cin̄en guerla eguiten / Luther Apoltotatari

$\mathrm{BCD}$

Apoltatari

Gainontzekoak

Halli bihotça arguicen / Infidel itfuari.

\section{- 238 orrialdea 4473 bertso zenbakia}

$\begin{array}{ll}\text { Eicolac cintuen bazter / Guztietan idequi } & \text { BCD } \\ \text { Ercoluac } & \text { CIEFGH } \\ \text { Licolua } & \text { I }\end{array}$

Hetan gazte errebel[ac / Verthutera iraiqui.

Azken hiru adibideotan, aldiz, BCD eta gainontzekoen irakurketaren arteko aldea letren gehiketan dago. Gure ustez, lehen bi kasuetan behintzat, lectio facilior baten ondorio izan daiteke aldaera: 'egun' > 'eguin' nahastu eta 'apostatari' hitza 'apostolu' hitzaren eraginez agian. Azken kasu honetan, gainera, hutsa gorengo edizioek dakarte, gainerikr(n) zuzendu egin dute.

Laburbilduz, orain arte eskeini ditugun adibideak argi erakusten dute $\mathrm{B}$ dela dugun lekukotasunik zaharrena edo stemmon goren jarri genezakeena. Badakigu, gainera, Bra edizio bakarra heltzen dela eta hau C edo D dela (gure ustez C. ajpatu arrazojengatik).

Jarrajan beste adibide mulizo bat aurke:tu nahi dugu: denetan ditugu huts bateratzaileak, EGHI edizioak batean biltzen dituzten hutsak. Noski, E edizioa bakarrik hartzen badugu, orduan Clekiko huts banatzaileak lirateke.

Hona adibideak:

\section{- 011 orrialdea 0058 bertso zenbakia}

\section{BCC 1 DF}

Etchearen leihoac çuc eztitutçu çarratçen, Rhima aitcitic ditutçu raroenac banatcen.

\section{EGHI}

Etchearen leihoac çuc

Rlima aitcitic ditutçu

raroenac banatcen

Mintzatuak gara zeharkako tradizioz heldutalio testuen atalean bertso sorta hauezaz. Arginaratzen bertsoak dira eta EGHIn 14. bertsoa falta da. Egin zuen P. I.aritck hur saiotxoa zuzentzen baina ikusia dugu ez zela zuzena izan.

Argi uzten du, bestalde. adibide honek multzo honetako biltek ( $E, G, H$ edo I) CI irakurlzen duela eta ez alderantziz, azken kasu bonetan C In ere bertso hau faltatuko litzatekeelako. Are, Fk ez luke kronologikoki zaharagoa den E irakurriko, bestela honetan ere bertso hau faltatuko litzateke. Beste bi datu garrantzitsu, bada. 
- 016 orrialdea

BCCIDF

Sankon humec eguinen dic

Obra handiagoa

Ceren garaituco baitu

Ifermuco campoa.
0115 bertso zenbakia

\section{EGHI}

Santon hunec eguinen dic

Obra handiagoa

Ifernuco campoa,

Ceren garaituco baitu.

\section{- 020 orrialdea 0191 bertso zenbakja}

Virginitatea gatic $33 /$ Iaun onac prophetia

Eman daroçu mereci / Ezginduen Caria dataçu

BCCIDF

EGHI

\section{- 048 orrialdea $\quad 0686$ bertso zenbakia}

Thhus eçaçue ceuen / Iauna beheratuá

BCCIDF

Iauhena beratua

EGHI

Ceruetan handi dena, / Lurrean ttipitua.

Hemen metatesi baten aurrean gaude, 'beheratua'ren 'he' aurreko hitzera pasatu da, 'Iauna'tik 'Iauhena'ra pasatuz. Hutsa lau edizioetako batek egin du eta gainontzeko hirurak ez dute zuzentzen jakin.

\section{- 091 orrialdea 0686 bertso zenbakia}

Ç.ordun ezten arren nahi / Du leguea complitu,

Teritu den guztiari / Emateco exemplu.

Eppheac iragatera / Nahi eztitu vtci,

Ecen iaio dela eztu / Egunic baicen çortci. ${ }^{34}$ BCC.IDF

Ecen iaio tuezdela

EGHI

Hau ere beste metatesi sinestezina da, baina hor dago lau edizioetan.

Uste dugu argi erakutsi dutela azken adibideok EGHII CIFtik aldentzen direla eta zuhaitz hipotetiko horretan beheragoko maila batean daudela. Jarraiko adibideotan EGHIren arteko erlazjoak eta zeinek zein irakurtzen duen zehazten saiatuko gara. Orain artekoarekin honelako zuhaitz moduko bat eraiki genezake:

\footnotetext{
3 "Sibyllen prophetia generalen gañean» du izenburu ahapaldi honek.

${ }^{34}$ Humeak zortzigarren egunean zirkutzisatzeko ohituraz ari zaigu Etxeberri.
} 


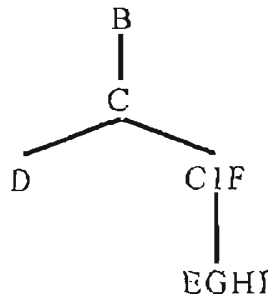

\section{- 139 orrialdea 2504 bertso zenbakia}

Arren bada Ielus Chrifto / Gloriofquj bitztua

Eguiqueguçu glorioz. / Cuc Bitzteco donua

$$
\begin{aligned}
& \text { Cuc Pizzteco } \\
& \text { Cuc Pityteco } \\
& \text { Cu Pituqui } \\
& \text { çupituqui }
\end{aligned}
$$

Oso interesgarria da locus criticus hau zuhaitzaren beheko parteko edizioen arteko harremanak aztertzeko. Hona hausnarketa batzuk:

1) Oso arrunta da CCIDFk egiten duten b/p aldaketa. Horrek ez du inolako eraginkortasunik.

2) Ek ez du 'z' hori ondo irakurri (agian kalte materialen bat zegoelako ereduan) eta 'z'ren ordez ' $y$ ' irakurketa eskaintzen du. Hau da honelako irakurketa dakarren bakarra.

3) Posibleena da gainontzeko edizioetako batek (G, H edo I) E hori jrakurri ela 'Cuc Pityteco' horri zentzurik aurkitu ez izana. Konposatzaileak edo editoreak, orduan, ezagunen egiten zaion hitzaz ordezkatzen du, 'supituki'. Gure ustez HIk jarraitu dute E (bi hitzetan dago jarria, ereduko itxurari jarraituz) eta Gk biak lotu baizik ez du egin.

4) Norbaitek esan dezake E delă H, I edo G irakuri dituena baina, gure ustez, ezinezkoa da hori, 'Cu Pituqui' horretatik 'Cuc Pityteco' Jortzea askozaz ere zailago eta sinesgaitzago delako.

\section{- 188 orrialdea}

3465 bertso zenbakia

$\mathrm{BCClDF}$

O Iainco Semea, arren
EGHI

Aitaren aitciñedn, ${ }^{3 !}$

\footnotetext{
35 ISE edizioan, lau bertsotako ahapaldi honetako lehena ('Aitaren astciñean') aurreko ahapaldiar'
} itsatsia dago; honela aurreko ahapaldiak bost bertso ditu eta honek hiru: 

Aitaren aitciūean,
O lainco Semea, arren
Caren ene ararteco
Caren ene ararteco
Heritura, eta menean.
Heritura, eta menean.

- 233 orrialdea

4372 bertso zenbakia

Eznuque feculan eguiu / O ran Francez, çureac,

Chehero condatu nahi / Banitu verthuteac

BCCIDF

verihureac

E

berri gureac

CiHl

Oso erraz nahas zitezkeen 't' eta 'i' eta hori da gertatu dena E lekukotasunan. GHIk 'verihureac' irakurri eta 'berri gureac' jarri dute. Hau ere adibide argia da GHIk E jarraitu dutela baieztatu ahal izateko.

\section{- 014 orrialdea $\quad 0078$ bertso zenbakia}

Ezteçala penfa gueure / Buruz mintço garela

BCCSDEF

$$
\text { miniço }
$$

E

GHI

Mintçaracitcen guiaitic/Gueure Iaunac hunela.

Oraingoan ere 'i/t' nahasi da E lekukotasunan eta GHIk guztiz desberdina den 'miriçu' egin dute.

\section{- 015 orrialdea 0106 bertso zenbakia}

Bere oiñen azpian dic / Buclaz erabjllico

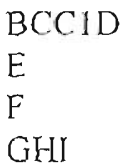

Haren captiuo guztiei / Bihotça alchatuco.

$\begin{array}{ll}\text { Buclrz } & \text { E } \\ \text { Buchlaz } & \text { F } \\ \text { Buluci } & \text { GHI }\end{array}$

Bat ere argi ez dagoen pasartea dugu hau; lehen lau lekukotasunetan 'Buclaz' ikus genezake. N'velac liburuko lehen noela da, "Propheten aguintça generalen ganean. Abendocntz" izenburupean bilizen dena eta Jesus Umearen etorreraz mintzo zaigu. Pasarte honetara heldu aurtetik heriotzaz mintzo da eta gure ustez hemen adierazi nahi dena zera da, Jangoikoaren Semeak Bere oiñen azpian erabiliko duela (heriotza, noski) 'buclaz'. 
Eranskinetan ikus daitekeen bezala, oso erraz nahas zitezkeen 'c' eta ' $r$ ' inprentako letretan eta hemen hori da gertatu dena, 'burlaz' jarri beharrean 'buclaz' dugula. Izan ere, oraingo honetaz gain, beste hamazortzitan aurkitu dugu 'burla' edo 'burlatu' Etxeberriren hiru liburu inprimatuetan ( 3 aldiz Noelacetan - 1.273, 1.915 eta 1.947 bertsoak-, sei aldiz Manualean -M1: 1.288, 2.265, 2.877 eta 2.880, M2: 1.087, 1.205-eta 9 aldiz Eliçaran $-1.085,{ }^{36} 634 \mathrm{~L}, 715 \mathrm{~L}, 910 \mathrm{~L}, 946 \mathrm{~L}, 3.139,4.822,6.373$ eta $7 .(92)$.

- Bestalde, argi dago E, F eta GHII nork bere bidea hartu dutela.

\title{
- 041 orrialdea 0544 bertso zenbakia
}

Herfu cenean Virgina / Erditceco ordua,

Erromatic ethorri cen // Auguftoren manua

$\mathrm{BC}^{37} \mathrm{D}$
$\mathrm{Cl}^{33} \mathrm{EF}^{39}$
$\mathrm{GH}$
$\mathrm{I}$

- 047 orrialdea $\quad 0666$ bertso zenbakia

Emaguin̄aren, etçuen / Nihola ere bebaric Niola BCCIDF Nihor E GHIT

Cerengatic ezbaitçuen / Sentitu doloreric.

\section{- 073 orrialdea $\quad 1188$ bertso zenbakia}

Bere camelu handiac / Tuzle defcargaraci, Eta dohañac lehiei / Beffotan harraracie

\section{garraracie} ekarraci

\author{
BCCIDF - \\ $\mathrm{E}$ \\ GHI
}

\section{- 081 orrialdea 1336 bertso zenbakia}

Erregueac ceudecela / Haurraren adoratcen, Errepuftaren beguira / Herodes cen vnhatcen Herodescen

BCCIDF E

${ }^{36}$ Etxeberriren liburuetako bertsoak. maiz, liburu bat baino gehiagotan errepikatuak agertzen zaizkigu. Kasu honetan, MAN2, 50, 1205 eta ELIC 54, 1.085: 'Burla\% çutela MelTia berreguindu lonetic'

${ }^{37} \mathrm{CD}$ : aurreko orrialdeko deia 'Augufiroren' da.

${ }^{38} \mathrm{Cl}$ : Aurreko orrialdeko deia, aldiz, 'Auguftoren' dugu.

${ }^{39}$ F: Aurreko orrialdeko déia ere 'Aufloren' da. 
Herodetcen

$\mathrm{H}$

Herodeflen

GI

Hemen ere zenbait kontu aipagarri:

1) Ek, agian bi hitzen arteko tartea nahiko estua zelako, bi hitzak lotu eta 'Herodescer' hartu du.

2) Hk E irakurri eta bokale arteko 'IT hartu du; GIk 'Herodefren', soberan zegoen 'c' hori desagertaraziz. Hk GI irakurri izan balu ez zen 'c' hori agertuko; are, oso zaila izango zen Glk E irakurri eta 'Herodescen' horretatik 'Herodelfen' egitea.

\section{- 114 orrialdea 1998 bertso zenbakia}

$\begin{array}{cl}\text { Vrricalduric vtcico / Cutelaco vftean } & \text { B } \\ \text { Curelo } & \text { CCIDEF } \\ \text { Cruela } & \text { GHI }\end{array}$

Açotera condemnatu / Cuen harroñ batean.

Esan dugu (\$3.3.1.1.1.) B edizio bat Aren eratoria dela baieztatu ahal izateko zera gertatu beharko dela, Bk Ak dituen huts guztiak aurkezten dituela eta, gainera, bere berezko hutsen bat. Argi dago, bada, azken adibideotan, GH multzoa Eren eratorria dela eta honela irudika genezakeela:

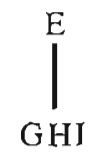

Hona jarraian GHI biltzen dituen adibide gehiago:

- 009 orrialdea 0033 bertso zenbakia

Erdaldunac ahal doazque / Cein bere herritara

BCCIDEF

Ecaldunac

$\mathrm{H}$

Escaldunac

G

Escaldunac

Gogat eguinic, galduco/Eziutela Efcara.

- 011 orrialdea

0058L bertso zenbakia

Liburucho hunec laur par- / te ditu

BCC1D

Liburucho hunec laur / parte ditu

$\mathrm{EF}$

Liburucho hunec laur paste. / laur ditu

G

Liburucho hunec laur / parte laur ditu

HI

- 026 orrialdea $\quad 0278$ bertso zenbakia 
Hec aguindu çuten Iauna / Guc dugu beguietli

BCCIDEF

berefi

GHI

Ecen gu guintuen bere / Apoftolu hautetfi.

- 032 orrialdea $\quad 0393$ bertso zenbakia

Hegalec ere cioten / Arguitcen lorbaldetan

$B$

Hegaiec

CC.IDEF

Hedoiec

GHI

Falconaren plumec nola / Iguzqui arraictan.

- 039 orrialdea 0517 bertso zenbakia

Ceru lurretan çaitçula / Laudorio cantatu,

Ene ohoratceco ceren / Hambat çaren bachatu

BCCIDEF nechatu

$\mathrm{GHI}$

- 040 orrialdea 0539 bertso zenbakia

Erdi cenean, Virgina // Bihurtu cen etchera,

Bera ere hurbiltcen cen / Erditce epphera

BCCIDEF

Eta

GHI

\section{- 047 orrialdea 0675 bertso zenbakia}

Amac affe çuenean / Eta vngui vnhatu:

Demborac cuitfan beçain / Vngui çuen trochatu

BCCIDEF hotfan

$\mathrm{GHI}$

- 104 orrialdea

1791 bertso zenbakia

Eta plaga hauc guztiac / Behar çaizquiñ guerthatu,

Cergatic eztunen ene / Bilita eçagutu

BCCIDEF eztun ene

$\mathrm{GHI}$

\section{- 123 orrialdea 2188 bertso $x e n b a k i a$}

Orduan cen eguietan / Frogatu efcritura,

Hiltoria aipphatcean / Norc eztuque latztura

B

$$
\begin{aligned}
& \text { eztugue } \\
& \text { eztugun }
\end{aligned}
$$

CC1DEF

GHI

\section{- 132 orrialdea}

IZ3 bertso zenbakia

Nola Aingueruec manatu cituen Aphoftoluei berria ekhar ciecen 
ciren GHI

- 144 orrialdea

1602 bertso zenbakia

Olibethco mendiaten / Garacitera da igan

BCCIDEF

dadiñan

$\mathrm{GHI}$

Ama eta Apoltoluei / Azken hitçac han eman.

- I83 orrialdea 3378 bertso zenbakia

Gu ere orobat gare/Eguitera tenitu

BCCIDEF

obtenitu

$\mathrm{GHI}$

Ceren baitugu ontaflun Alco errecibitu.

- 186 orrialdea 3433 bertso zenbakia

Iainco eme Senegatic / Guiçon eguin cinena

BCCIDEF

Seme enegatic

GHI

Ecin bihur dieçaqueçut / Laudorio çucena.

- 196 orrialdea

3633 bertso zenbakia

Han penaraci cintuen / Ecin erran guifara penari

BCCIDEF

$\mathrm{GHI}$

Erchatcen cinituela / Bere fecta gaixtora.

- 208 orrialdea $\quad$ IZ1 bertso zenbakia

Edoceir emazte lainduren beftacotz

beftetacotz

BCCIDEF

$\mathrm{GHI}$

\section{- 220 orrialdea $\quad 4097$ bertso zenbakid}

Ene ondoan heldu da / Ni baño lehen cena.

BCCIDEF

$\varnothing$

GHI

Erregue eta Monarka / Guztietaco lehena.

Orajn aurkezten ditugun adibibeek Fk jarraitu duen bidea argitu nahi dute.

Fk dakarren lehen aldaketa nabaria inprenta oinarena da: CC1DEk «Maffre baitan, bors / Cantognetan» duten bitartean, honek «P. Fauveten, Imprimerian / Carmellen aldean» du. Zazpigarren kapituluan luzaz mintzatuko garen arren, derragun P. Fauvet hau Paul Fauvet izan daitekeela eta honek 1700-1736 bitartean inprimatu zuela. Argi legoke, bada, aurreko inprenta oinen datak zuzenak izatekotan, CCIDE edizioak 1697 (bi) eta 1699 (beste biak) urteetakoak direla eta $F$ hau beranduagokoa dela, 1700-1736 urte bitartekoa. 
Hori da kontuan izan beharreko lehen datua. Bigarrena, aurrekoek ez eta honek liburuaren amaieran dituen zenbait bertso berri: Izan ere, 241 . orrialdean hasita, 10 orrialdetan zehar, jarraiko bertsoak ditugu:

241 -248. or.: "Verbum caroac. Efcaraz Chrifto guiçon eguinda çure ganic Maria" 249-250. or.: "Egun estreinatu gaitu Haurrac odolaz."

Bertso hauek amaieran jartzearen arrazoi posibleaz ere zázpigarren kapituluan mintzatuko gara.

Argi dago, gure ustez, aurreko lekukotasunen batek F hau janaitu izan balu bertso havek agertuko ziratekeela lekukotasun horretan, eta hau ez da gertzatzen; are, ondorengo (ifHI lekukolasunek ere F jarraitu izan balute bertso hauek ispilatuko zituzketen beraien orvialdeetan eta ez da horrela gertatzen; beraz, badirudj $F$ edizio honek aurrekoren bat izan duela eredu (orain arte aztertu ditugun huts amankomunen arabera, $\mathrm{Ci}$ da lekukotasun hori) eta $F$ hau ez dela ondorengo edizioren baten eredu.

Hutsei beraiei dagokionez, F edizioan agertzen diren asko ez dira huts amankomuntzat hartuak izan genitzakeenak; baliogabeak, beraz, lekukolasun honen filiaziorako. Hauen artean aipagarrienak:

a) duplografia ạrunt bezala har genitzakeenak

$\begin{array}{llll}029 & & \text { F } & \text { Gainontzekoak } \\ 060 & 0342 & \text { Eeliçama } & \text { Eliçama/Eliça Ama } \\ 060 & 0924 & \text { Betheleengo } & \text { Bethleengo } \\ 066 & 1044 & \text { Ereifiaz } & \text { Erefiaz } \\ 096 & 1636 & \text { leialia } & \text { leiala } \\ 114 & 1992 & \text { Ioingoico } & \text { Iongoico } \\ 209 & 3879 & \text { Eçatgutu } & \text { Eçagutu } \\ 229 & 4295 & \text { verthuetera } & \text { verthutera/vertutera } \\ & \text { Hondaitçaille } & \text { Hondatçaille }\end{array}$

b) Haplografiatzat har genitzakeenak

$\begin{array}{llll}012 & 0066 \mathrm{~L} & \text { Hirugarrena } & \text { Hirurgarrena } \\ 047 & 0663 & \text { mundatçaric } & \text { mundantçaric } \\ 074 & 1208 & \text { ttpia } & \text { ttipia } \\ 129 & 2321 & \text { ikhratu } & \text { ikharatu }\end{array}$

c) Ordenaren aldaketaz gertalzen direnak

$\begin{array}{llll}072 & 1164 & \text { Ceturic } & \text { Cerutic } \\ 091 & 1545 & \text { eratcufico } & \text { eracuẗ̈co } \\ 205 & 3799 & \text { âdiquide } & \text { adilquide }\end{array}$


d) Ordezkapenez gertatzen direnak; gebienetan inprentako zenbait letra berdintsuak oso erruz nahasten zirelako.

$\begin{array}{llll}014 & 0072 & \text { Idecat } & \text { Idecac / Ideac }(\mathrm{c} / \mathrm{t}) \\ 046 & 0652 & \text { Egnin } & \text { Eguin }(\mathrm{n} / \mathrm{u}) \\ 175 & 3274 & \text { bailchen } & \text { bai lehen }(\mathrm{c} / \mathrm{e}) \\ 208 & 3871 & \text { liçatc } & \text { liçate }(\mathrm{c} / \mathrm{e})\end{array}$

Baina huts guzti hauezaz aparte, hain enraz gerta ez litezkeen edo huts amankomuntzat har daitezkeen asko daude, F lekukotasun honek besteck jarraitu ez duten bidea jarraitzen duela baieztatzen lagunduko digutenak.

a) Hizkiren baten gehiketaz gertatzen diren hutsak

$\begin{array}{llll}025 & 0265 & \text { duedenean } & \text { duenean } \\ 050 & 0727 & \text { Sehafcharic } & \text { Sehafcaric } \\ 061 & 0941 & \text { Semeac } & \text { Semea } \\ 068 & 1091 & \text { Icarrac } & \text { Içara } \\ 217 & 4027 & \text { Berriac } & \text { Berria }\end{array}$

b) Hizki/hitzen bat desagertzen denean gertatzen direnak

$\begin{array}{llll}009 & 0039 & \text { Etcheberri } & \text { Etchebertic } \\ 071 & 1155 & \text { bihurtcen } & \text { bihurtcean } \\ 138 & 2491 & \text { Iainduc } & \text { Iainduec } \\ 144 & 2609 & \text { du } & \text { dut } \\ 171 & 3144 & \text { Ceiña } & \text { Ceñac/Ceiñac } \\ 212 & 3952 & \text { arartecoa } & \text { arartecoac } \\ 232 & 4352 & \text { Jauna } & \text { Iaunac/Jaunac } \\ 233 & 4363 & \text { guiçona } & \text { guiçonac }\end{array}$

c) Ordezkapenez gertatzen direnak

$\begin{array}{llll}027 & 0311 & \text { Ceñan } & \text { Ceñac } \\ 051 & 0755 & \text { lutela } & \text { dutela } \\ 052 & 0766 & \text { lauratu } & \text { loratu } \\ 058 & 0894 & \text { Gateuzte } & \text { Gaituzte } \\ 068 & 0172 & \text { Ceren } & \text { Ciren } \\ 069 & 1110 & \text { Sartceaz } & \text { Sortced } \\ 071 & 1143 & \text { dut } & \text { duc/duo } \\ 075 & 121 & \text { era } & \text { ere } \\ 088 & 1486 & \text { Garacen } & \text { lartce } \\ 179 & 3294 & \text { gaitu } & \text { çaitu }\end{array}$

Gure ustez, bada. azaldu ditugun adibideok, hutsez landako inprenta eta urte kontuak 
eta amaierako bertso desberdinenak aintzat harturik, zilegi dirudi $\mathrm{Cl}$ eta $\mathrm{F}$ maila desberdinetan daudela adieraztea eta lortu ditugun bi azken zuhaitz adarrak kontuan hartzen baditugu:
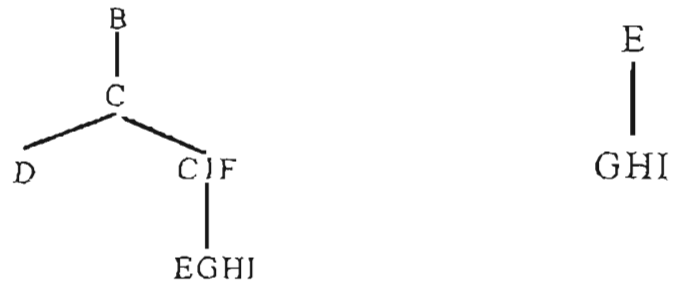

uste dugu aurrerago joan gaitezkeela eta jarraiko hau aurkez genezakeela

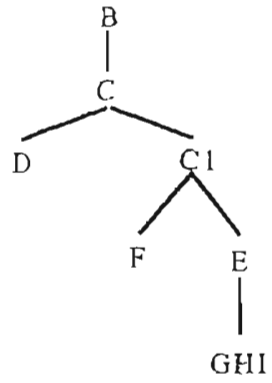

Argi dago EGHIk ez dutela F jarraitzen eta bai $\mathrm{Cl}$, aurkeztu dilugun azken adibideek hori erakusten baitute (ez dago EGHIn Fn bakarrik agertzen den bat ere).

Aurera egin eta kronologikoki azkenak diren GHI edizioez mintzatuko gara jarraiko lerroetan eta horretarako G lekukotasuna aztertuko dugu, lehenik eta behin.

Noelacen hirugarren partean. Gk ez eta gainontzekoek jarraitzen duten bertsoen ordena honako hau da:

Laincoari orenac gulf̧az duen ... Iyandetacotz

B eta gain. $\quad G$

lainco bat denari... Aüelehenecokz

$178-180$

147-149

Hirurtall unaren orenac Aujeartecotz

$180-182$

$149-150$

lainco Aitaren orenac Aüeazkenecolz.

$182-184$

$150-152$

lainco femearen orenac orcegunecotz...

$184-186$

Efpiritu fainduaren orenac orciralecot

$186-188$

$152-153$

Ama virginaren orenac larunbatecolz

$188-189$

$153-154$

Sainduen orenac... Apofioluen befteracorz

190-192

$155-156$

Euangeliften beftetacotz

$192-193$

$189-190$

Martiren beftetacotz

194-195

156-157

Ipphizpicu lainduen beftetacolz

195-197 
Doctor fainduen beftetacotz

199-201

193-195

Abbadeen beftetacotz

$201-202$

$157-159$

Gn, bada, «Iainco Aitaren orenac Afteazkenecotz», 38 bertso falta dira. Bestalde, "Sainduen orenac hequin beftetacotz. Apoftoluen beftetacotz», «Martiren beftetacotz», «Ipphizpicu fainduen beftetacotz» eta «Doctor fainduen beftetacotz» bertso sortak tokiz aldatuak dira, liburuaren azken partean jarriak.

Mintzatu gara 5. kapituluan kopiatze prozesuaz aritu garenean bertsoen toki aldaketa honetaz. Guk bi arrazoi posible eman ditugu: 1) Eredu izan duen alea sorta desberdinetan banatu da zenbait arazoren ondoren eta berriro bildu denean okerreko ordenean bildu dira; orduan konposatzaileak ereduko ordena jarraitu du, halabeharrez. Horrek eredu izan duen alean bertsook plegu haseratan zeudela suposatu beharko zukeen, baina hori ez da horrela gertatzen gainontzeko edizio batean ere. 2) Bertsook bertso ahapaldiak dira, ez bertso atalak edo bertso solteak, eta, konposaketa prozesua azeleratu asmoz, konposatzaile desberdinek atal desberdinak konposatu dituzte eta biltzerakoan okerreko ordenean bildu dira. Uste dugu hirugarren arrazoi posible bat ere eman daitekeela: editoreak edo inprimatzaileak nahita lekuz aldatu izana. Kasu honetan, aldaketa kontziente baten aurrean geundeke, baina ez diogu logika gehiegirik aurkitzen bertso guztiok osotasun bat egiten baitute.

Hau da lehen kontu garrantzitsua. Bigarrena letra maiuskula eta minuskulei dagokiena da. G lekukotasunan, 87. orrialdetik aurrera, bertso haserako lehen letra, edizio honetako lehen 86 orrialde eta gainontzeko lekukotasunetan ez bezala, minuskulaz dugu jarria kasu gehienetan; honela, maiz, maiuskula beharko zukeen kasuetan ere (hitz bereziak) minuskula dugu.

Hirugarten kontu garranizitsua, 'guztiak/guziak' erako aldaerena; G edizio honetan, 104. orrialdean hasita, 'guziz', 'guzia', 'guzien', 'guziei', e.a. ditugun bitartean, aurreko orrialdeetan eta gainontzeko edizioetan 'guztiz', 'guztia', 'guztien', 'guztiei' e.a. ditugu.

Hirı kontuok, gure ustez, zera adierazten dute, konposatzaile batek baino gehiagok konposatu duela edizioa eta ez dela inolako arretarik jarri hau egiterakoan.

Laugarren kontu garrantzitsu bat, GHI lekukotasunei dagokiena; amaierako bertso berrien kontua. Ikusi dugu F lekukotasunak azken hamar orrialdeetan zenbait bertso berri aurkezten zituela; hauek ere bertso berri batzuk dituzte, izatez Noelacenak ez direnak. Baina ez dira Fn agertzen direnak, bestelakoak baizik. Hauek dira:

- «Stabat Mater» euskaraz, 69 bertsotan zehar.

- «Andredena Mariari Othoitça. Gaudeac» 24 bertso latinez.

- «Andredena Mariari Hymnoa» 60 bertso latinez (Stabat Mater da).

- «Erregueren Orationea. Psalmoa» 46 bat lerro latinez.

Hutsei beraiei dagokionez ere, askotxo dira Gk baizik erakusten ez dituenak. Jarraian azpimarragarrienak aurkeztuko ditugu (den denak aztertu nahi dituenak jo beza 
eranskinetara):

a) Gehiketaz gertatzen direnak

$\begin{array}{llll}023 & 0237 & \text { Monarcha } & \text { Monarca } \\ 024 & \text { IZ1 } & \text { Agripinna } & \text { Agrippina } \\ 040 & 0539 & \text { here } & \text { ere } \\ 043 & 0596 & \text { Bethleenen } & \text { Bethleen } \\ 085 & 1419 & \text { Hazri } & \text { Hari } \\ 102 & 1749 & \text { eta } & \text { ea } \\ 130 & 2340 & \text { gorphutça } & \text { Gorputca } \\ 159 & 2904 & \text { guztian } & \text { guztia } \\ 176 & 3253 & \text { Labour } & \text { Labur } \\ 194 & 3594 & \text { Guendetan } & \text { Gendetan } \\ 233 & 4370 & \text { oifän } & \text { O Gan } \\ 234 & 4404 & \text { deitchatu } & \text { deithatu } \\ & & \\ \text { b) Hizki/hitzen bat desagertzen derean }\end{array}$

\section{- 045 orrialdea $\quad$ IZ3 bertso zenbakia}

Bethleenen oftaturic ecin / aurkhituaren gañcan / berce / Noela. BCCIDEFHI Bethleenen oftaturic ecin / aurkhituaren gañean / Noela. G

$\begin{array}{llll}081 & 1336 & \text { HerodeSen } & \text { Herodes cen/HerodelTcen } \\ 085 & 1420 & \text { Etaz } & \text { Ezta } \\ 101 & 128 & \text { Hierufalemen } & \text { Hierufalemera } \\ 107 & 1857 & \text { hartaz } & \text { hartçaz } \\ 107 & 1861 & \text { hautaz } & \text { hauţaz } \\ 114 & 2006 & \text { açotez } & \text { Açoteez } \\ 117 & 2057 & \text { Dolorez } & \text { Doloreez } \\ 118 & \text { IZ1 } & & 7 \text {. } \\ 120 & 2123 & \text { hartaz } & \text { hartçaz } \\ 121 & 2143 & \text { cituzten } & \text { cintuzten }\end{array}$

\section{- 123 orrialdea IZ2 bertso zenbakia}

Gurutcearen ohoretan canta, / gurutcearen befietacolz. Gurutcearen ohoretan, canta.

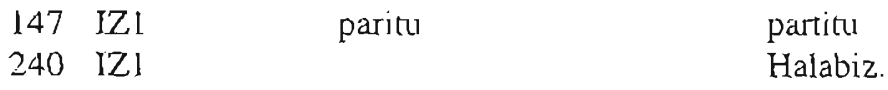

c) Ordenaren aldaketaz gertatzen direnak

0941604 barnera barrena


d) Ordezkapenez gertatzen direnak

$\begin{array}{llll}005 & 001 \mathrm{LL} & \text { devotionem } & \text { deuotionearidevodionean } \\ 016 & 0107 & \text { Hatcen } & \text { Haren } \\ 023 & 0230 & \text { Dilluduen } & \text { Da Iuduen } \\ 023 & 0230 & \text { berria } & \text { herria } \\ 030 & 0351 & \text { berric } & \text { berriz } \\ 037 & 0490 & \text { Gaituzte } & \text { Caituzte }\end{array}$

\section{- 046 orrialdea 0644 bertso zenbakia}

Ulkhi direnean dute / Bazterrera behatu, Eta appartean erche / Cholabat nauaritu.

Cholabac nauritu BCCIDEFHI

Cholabac caucitu. $\mathrm{HI}$

G

$050 \quad 0724$

$068 \quad 1093$

$072 \quad 1167$
Guztic

Oçucia

beraiz
Guztiz

O çucia/O çucia ${ }^{41)}$ beriz

\section{- 101 orrialdea}

\section{IZ8 bertso zenbakia}

Yefus Chriftoren Hienfalemera fartcearen gañean Arramucotz Canta

$B C D$ lortcearen

Hieru[alemerã "

Hierufalemen »

Hierutamelera

1. Nola Hierufalemera afto gañean farthucen

Hierusalamera

Hierufamelera
CIEH

$\mathrm{F}$

G

Canra I

BCCIDEFH $\mathrm{G}$

I

Bi esaldiok orain arte azaldu dugunaren ezaugarri baliogartia dira; lehenean, $B C D$ bide argia ikusten da. Bestalde, argi dago HJk ez dutela G jarraitu, bestela, 'Hierufalemen' irakurriko genuke bi lekukotasunetan.

$\begin{array}{llll}106 & 1839 & \text { cuen } & \text { ceuen } \\ 107 & 1852 & \text { guriz } & \text { Guztiz } \\ 110 & 1914 & \text { elkhari } & \text { Ekharri } \\ 111 & 1929 & \text { Nazarecoac } & \text { Nazarenoac }\end{array}$

- 117 orrialdea 2056 bertso zenbakia

40 15h eta 15 i edizioetan tartea nahiko txikia da. 
Egarri cela ceroen / Erran Iudu gaixtoei:

Miagrea prefentatu / Haren ezpain lainduei

Gainontzekoak

G

Vrruitira/Urruitira

Cure miagrea azpian
$125 \quad 2236$

$128 \quad 2291$

- 128 orrialdea
Urritera

çare

\section{1 bertso zenbakia}

Cure baithan dire Chriftau / Guztiac gloriatcen

Cure baithan dute bere /E: Iparanţ̧a ematen.

çare baitban

Gainontzekoak

G

Gainontzekoak

G

Vnguentu onez launaren / Gorputça gantçutcera.

$138 \quad 2484$

$141 \quad 2553$

hillac

Hillic

Curi

Guri

$171 \quad 3156$

cutçaz

gogoiqui

Gutçaz

$207 \quad 3848$

nagoënaten

gogorqui ${ }^{41}$

2194088

azkenençar

Dagoenarer/Dagoënaten

azken fijean/azkennean/azkenenean

$226 \quad 4234$

Argi erakusten dute azaldu ditugun lau kontuak eta erakusgarri jarri diren hutsen adibideok HIk ez dutela G jarraizen, bestela ez ziratekeen Gn falta diren bertso sortak agertuko eta bertsoen ordena bera ere aldatua agertuko baitzatekeen. Are. Gn agertu diren hutsak ere ez dira inondik ageri HI lekukotasunetan.

Aurreko orrialdeetan, bestalde, GHI biltzen zituzten huts bateratzaileei zegozkien adibideak ikusi ditugu; beraz, GHI biltzen dituzten huts bateratzaileak baditugu eta, era berean, $\mathrm{G}$ beste biengandik banatzen duten huts banatzaileak, argi dago lekukotasunek jarraitu duten bidea honako hau dela:
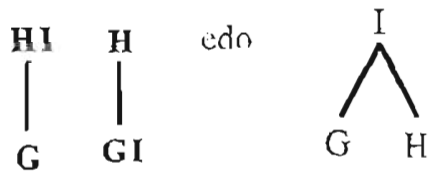

. ez baitugu GH edo GI biltzen dituzten huts

amankomun argiak lortu.

Jarraian HI lekukotasunen arteko erlazioa aztertuko dugu, bi lekukotasunak lotzen

41 ' $r$ ' hau oso gutxi ikusten da eta 'i' baten antza duela ematen du 15 h edizioan. 
dituzten zenbait huts bateratzaileren adibideak jarriz.

a) Gehiketaz gertatzen direnak
$099 \quad 1714$
Ukhutri
IkhulTi
$107 \quad 1862$
belkhaizten
bekhaizten/bekhaizte

- 125 orrialdea

2227 bertso zenbakia

Cuc ekharri darocuçu / Biciaren fruitua, Arima golleei eman / Cuc laciamendua gotToeei

Gainontzekoak HI

- 185 orrialdea 3425 bertso zenbakia

Gauça hauc ciruenean / Sei egunez obratu, Guero cindu en Igande / Egunean paufatu Gainontzekoak cinduen en $\mathrm{HI}$

- 186 orrialdea 3432 bertso zenbakia

Arren bada Iainco Aita / Gaucen creatçaillea, Fauora naçaçu ceure / Creatura feblea

Gainontzekoak febleac HI

b) Hizki/hitz baten desarerpencz gertatzen direnak

$\begin{array}{lll}122 & 2173 & \text { Veperatan } \\ 160 & 2932 & \text { nior } \\ 184 & 1 Z 1 & \text { Ainco } \\ 185 & 3414 & \text { beatu } \\ 209 & 3895 & \text { trimpharequin }\end{array}$

Vezperatan/Velperatan nihor Iainco behatu

c) Ordenaren aldaketaz gertatzen direnak

$\begin{array}{llll}200 & 3704 & \text { bantacen } & \text { banatcen } \\ 215 & 3993 & \text { aitcieñtic } & \text { aitciñetic }\end{array}$

d) Ordezkapenez gertatzen direnak

\section{- 013 orrialdea $\quad 0074 \mathrm{~L}$ bertso zenbakia}

Ielus Chriftoren fortce aitci/ñeco Gaucen gañean Noëlac 
Eta sei lerro geroago:

lefus Chriltoren fortce ait/ciñecogaucen gañean Noëlac BCCIDF aitciñeo E aitciño HII aitcino

$\mathrm{G}$

Lehen adibidean, 'aitciñeco' dugu BCC1DEF lekukotasuneıan; HIk 'aitciñeca' dakarte eta Gk 'aitciñera'. Gk E irakurri izan balu ('aitciñeco'), ez zukeen egin duen 'aitciñera' ori egingo; 'aitciñeca' irakurri eta 'aitciñera' zuzentzea logikoagoa da; hau da, logikoagoa da Hk E irakurri izana eta gero Gk $\mathrm{H}$ eta ez Gk E irakurri eta Hk G.

Bigarren adibidean, 'aitciñeco' dugu lehen sei lekukotasunetan. Dena den, harrigarria dirudi sei lerro aurterago konposatu duten esaldi berbera ondo berkonposatu ezina. Argi erakusten du honek ez zela inolako konturik eta harretarik jartzen garai hartako inprentan konposatzerakoan (Noelacen edizio desberdinetan behintzat).

$178 \quad I Z 2$

- 013 orrialdea
HVNEN/HUNEN
Larumbatean cintuen / Moldatu lar'abreac

lare abreac
Gainontzekoak

$\mathrm{HI}$

\section{6}

Ohorec

Ohorez

Adibide guztiok argi erakusten dute HI lekukotasunen lotura.

Azkenik, I lekukotasuna besteengandik aldentzen duten hutsak jartiko ditugu:

a) Gehiketaz gertatzen direnak

$\begin{array}{llll}020 & \text { IZ1 } & 239 . & 39 . \\ 022 & 0222 & \text { caltera } & \text { caltea } \\ 024 & 0262 & \text { huriora } & \text { herioa } \\ 027 & \text { IL4 } & \text { Cucloac } & \text { Credoa }\end{array}$

\section{- 146 orrialdea 2650 bertso zenbakia}

Ezta hala içanen (erıan / Ceroen Iaun iuftuac)

Gainontzekoak

(erran / Ceroën

$\mathrm{H}$

(erran / ceroën

G

/ Ceroën laun iuftuac erran

Conlolatuco çailuzle Spiritu lainduac. 


$\begin{array}{llll}153 & 2787 & \text { animac } & \text { anima } \\ 153 & 2794 & \text { Elcou } & \text { Elcu } \\ 166 & 3058 & \text { Guztiac } & \text { Guztia/guzia } \\ 181 & 3347 & \text { çucenac } & \text { çucena } \\ 204 & 3780 & \text { Hartean } & \text { Artean }\end{array}$

b) Hizki/hitz baten desagerpenez gertatzen direnak

$\begin{array}{lll}037 & 0489 & \text { gorc } \\ 042 & 0581 & \text { ignataci } \\ 047 & 0669 & \text { citçain } \\ 058 & 0886 & \text { billatu } \\ 064 & 1020 & \text { bamean } \\ 066 & 1056 & \text { frogatu } \\ 069 & 1103 & \text { dut } \\ 093 & 1586 & \text { Iaun } \\ 113 & 1983 & \text { burd } \\ 122 & 2170 & \text { iuftuaren } \\ 131 & 2358 & \text { Darotçue } \\ 138 & 2492 & \text { illarria } \\ 159 & 2909 & \text { Ona } \\ 159 & 2912 & \text { Ig̣uzquia } \\ 164 & 3013 & \text { Faindua } \\ 179 & 3310 & \text { chehea } \\ 183 & 3368 & \text { çuait\% } \\ 212 & 3950 & \text { Caitucticiod }\end{array}$

gorec

iganaraci

citçaion

billhatu

barrenean

frogatua

dute

Iauna

burla

iuftuarena

DarotçuevDarotçuec

illharria

Onac

Iguzquiac

fainduac

cheheac

çuhairz

[aihet fecoac

c) Ordenaren aldaketaz gerlatzen direnak

$\begin{array}{lll}029 & 0333 & \text { iaquiñena } \\ 029 & 0345 & \text { aouatcen } \\ 044 & 0619 & \text { Arrenac } \\ 059 & 0906 & \text { Ialutaceco } \\ 073 & 1176 & \text { Oratçarri } \\ 093 & 1577 & \text { benedica } \\ 120 & 1 Z 1 & \text { onerac }\end{array}$

iaquiñean

auoatcen

Artañec/Artanec

[a]uatceco/[avatceco/Iauatceco

Oratçari

bedinca

orenac

d) Ordezkapenez gertatzen direnak

$\begin{array}{llll}005 & 0004 \mathrm{~L} & \text { ifpiritualezco } & \text { efpiritualezço } \\ 051 & 0739 & \text { deçu } & \text { duçu } \\ 052 & 0769 & \text { Arrañic } & \text { Arrañac } \\ 055 & 0831 & \text { Belhaunico } & \text { Belhaurico } \\ 055 & 0835 & \text { belhaunjeo } & \text { belhaurico } \\ 058 & 0898 & \text { belhaunico } & \text { belhaurico } \\ 059 & 0902 & \text { Içurren } & \text { Içarren }\end{array}$


$\begin{array}{llll}064 & \text { i010 } & \text { glicia } & \text { çucia } \\ 065 & 1023 & \text { belhaunico } & \text { belhaurico }\end{array}$

- 07l orrialdea $\quad$ 0074L bertso zenbakia

O Bethleen Iudeaco / Ez hiri ttipiena!

$$
\text { Iudea co iri tripenea }
$$

Gainontzekoak G 1

Hire ganic illkhico duc / Erregue Iuduená.

$\begin{array}{llll}071 & 1149 & \text { deçuena } & \text { duçuena } \\ 074 & 1196 & \text { Belhaunico } & \text { Belhaurico } \\ 088 & 1487 & \text { gochoa } & \text { gachoa } \\ 090 & 1520 & \text { circumtcifatcera } & \text { circuntcilatcera } \\ 091 & 1530 & \text { leguia } & \text { leguea/legua } \\ 091 & 1539 & \text { deçu } & \text { duçu } \\ 091 & 1541 & \text { deçu } & \text { duçu } \\ 091 & 1545 & \text { deçu } & \text { duçu } \\ 092 & 1566 & \text { circumcifatu } & \text { circuncifatu } \\ 094 & 1594 & \text { Segurantçac } & \text { Segurantçaz } \\ 094 & 1596 & \text { maitia } & \text { maitea }\end{array}$

\section{- 099 orrialdea}

\section{9 bertso zenbakja}

Azkenean etfituric / Templuan ciren farthu aurquituric ${ }^{42}$

Gainontzekoak 1

Eta han çuten difputan / Dotorequin aurkhitu.

$\begin{array}{llll}100 & 1729 & \text { Patientique } & \text { Patientqui } \\ 101 & 1 Z 7 & \text { ifpiritualac } & \text { elpiritualac } \\ 108 & 1886 & \text { Pharifauac } & \text { Phari Tauec/Pharifavec } \\ 109 & 1 Z 1 & \text { Soiduaren } & \text { Cainduaren }\end{array}$

- 112 orrialdea 1957 bertso zenbakia

Diruz corronpitu çuten / Haren elpenlaria Gaunontzekoak

${ }^{42}$ Bi bertso geroago 'aurkhitu'ren ondorioz, ziurren. Ahapaldi osoak honela dio:

Azkenean aurquituric! Templuan ciren farthu

Eta han çuten / Dotorequin aurkhitu

Ikus, bestalde, 'aurquituric' ela 'aurkhitu' hiru lerroren buruan. 
ciren. ${ }^{43}$

I

Ceñac muffu batez faldu / Baitçuen Nauflia.
$124 \quad 2199$
gucis
çuciz/çucis
$133 \quad 2390$
pagatu
pagutu

- 139 orrialdea

2506 bertso zen bakia

Ea Guiriftinoac Bazco / Egunean biz gaiten

Gainontzekouk

gañen

I

Egun hunec berac gailu / Hartara gombidatcen.

$145 \quad 2624$

$156 \quad 2842$
Eguiteac

Cutaz
Eguiteaz

Gutçaz/Gutiıı

- 158 orrialdea

2897 bertso xenbakia

Hartçaz gaituiçu Iaun - ona / creaturac bazcatcen

$\mathrm{J}$ an on

Gainontzekoak I

Ceure odol facratuaz / Halaber edaraten.

$186 \quad 3439$

$190 \quad 3511$

gancan

gauean

2164019

ciçeu

civien

Gau

Hau

I beste lekukotasunetatik aldentzen duten adibideon aurean, aipa dezagun Hren arteko lotura

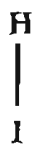

Hn, bestalde, ez dugu aurkitu Ik edo Gk ez dakarren huts banatzailerik. Guzti hauen aurrean, beraz,

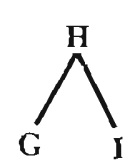

\subsubsection{Noelacen stemmata codicuma}

Noelacen lekukotasun desberdinen aldaeren azterketa eta aukeraketaren ondoren, ordea, huts amankomun - bateratzaile eta banatzaile - ugari aurkitu eta stemma codicuma marratzeko bezala aurkitzen garelakoan gaude.

\footnotetext{
1s Aurreko bertsoa 'Moian billatu ciren.' dugu.
} 
Hona, bada, proposatzen dugun obra honen lekukotasun desberdinen erakuspen grafikoa:

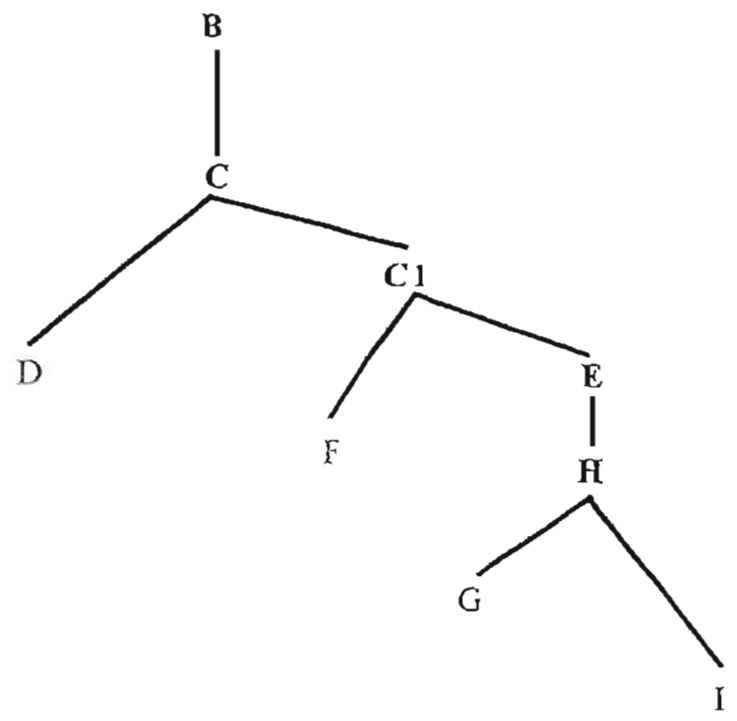

A. Blecuak dioenez (1987: 78), kodizeen data eta imprimaturiko testuena ezagutzen denetan, siglak garaiera desberdinetan kokatzen dira (baxuenek, logikoki, lekukotasunrik berricnak ordezkatzen dituzte) eta gure kasuan ere ohitura hau isladatzen saiatu gara.

Jakina da B lekukotasuna 1645 .ean inprimatua dela Bordelen, G. Milangesenean. C eta Cl lekukotasunak 1697 koak dira baina azken honek aurrekoa irakurtzen duenez beherago jarri dugu. D eta E 1699koak dira eta logikoa da bata bestearen mailan jartzea. F eta H Paul Fauvetenean inprimatuak dira eta hau honela dela (Paul Fauvetek 1700-1736 tartean inprimatzen du) biak maila berdintsuan jartzea erabaki dugu. G edizioa Jean Fauvetenean (1736-1760) inprimatua da eta aurreko biak baino beheragoko maila batean jarri beharko dugu. I lekukotasuna ere P. Fauvetenean inprimatua da. Gure ustez, P. Fauvet hau ez da $\mathrm{F}$ eta $\mathrm{H}$ inprimatzen dituen Paul Fauvet zaharra bere hiloba Paul, Jeanen seme, baizik. Paul honek — hurrengo kapituluan ikusiko dugunez - inprenta berria ireki zuen karmeldarren elizaren aldamenean. Honek eragin handia du, lekukolasun honen tipografia berria eta desberdina delako.

Kontu honekin amaitu aurretik argi utzi nahi genuke stemma codicum hau anker gelditzen dela hemen ez baitugu ez originalaz ez ustezko lehen edizioari buruzko zehaztasunik eman.

Argi dago aztertu ditugun lekukotasun guzti hauek goragoko testu batera doazela. 
Kasu honetan B lekukotasuna litzateke goragoko bat irakurri duena. Zein da, ordea, irakurri duen hori? Vinsonek bere bibliografian 15a zenbakiz izendatu eta Pierquin de Gembloux (1858a: 7 gehigarriak) aipatzen dutena ala originala?

Ez du gure lan honetan garrantzi gehiegirik kontu honek. Gure helburua eskuartean genituen lekukotasun guztien filiazio zuzena egitea zen eta, bidenabar, hauen erakuspen grafikoa eskaintzea eta, alde honetatik, helburuak beteak direlakoan gaude.

\section{Ondorioak}

Noelacen lekukotasun desberdinen huts amankomunen azterketak eta aukeraketak Vinsonek aipatzen dituen zenbait kontu argitzen eta zuzentzen lagundu digute eta, ondorioz, obra honen edizio desberdinen sailkapen bibliografiko berri baten beharrean aurkitzen gara. Iita kontu honetan du. gure ustez, orain aurkezten den lan honek benetako garrantzia, baldin eta garrantzia badu, lan osoan zehar aipatu ditugun zeregin guztiak bete ondoren, katalogatu gabeko edizio baten berri emateko ezezik, sailkapen berri hori aurkezteko ere gai baita.

Hona proposamen berri hau:

Na edizioa (Vinson, 15a)

"-NOELACETA BERCE canta efpiritual berriac. lesus Chrifforen biciaren myfterio principalen gañean. Eta fainduen ohoretan befia buruetacotz. Ioannes Elcheberri Dolor Theolognac equiñac. BORDELEN, G. MILANGES, 1630 edo 1631."

Ajta Larramendi da edizio honen berri ematen duen lehena, Baionán inprimatua dela dioen arren; Pierquin de Gemblouxek ere aipatzen du edizo hau eta Vinsonek suposatu baizik ez du egiten, bere ustez oso arraroa baita 1630.ean baimena lortu eta 1645.era arte inprimatu gabe izatea.

Ez dugu inon aurkitu edizio honen arrastorik.

Nb edizioa (Vinson, 15b)

"NOELAC IETA BERCE I canta elpiritual I berriac. | lefus Chriftoren biciaren my" | fierio principalen gañean. I Eta fainduen ohoretan befta buruetacotz. I loannes Etcheberri Dolor I Theologoac egniñac. I (fleuron) I BORDELEN, I GVILLEN MILANGES, Erre- I gueren Imprimatçaillea I baithan, 1645."

In-8 txikia erakoa, 251 orrialde. Neurriak: 45 mm x 98. Lcinadurak: A p. I, B p. 17, C p. 33, e.a.

P. de la Masse Donibane Lohitzuneko apaizak eta P. de Urthubie Teologian doktoreak baitetsia, 1630.eko abuztuaren 6an. Baimena, Manual-ean legez, M. d'Oiharard Bikario Jeneralarena da, urte eta hilabete berbereko egun bi beranduagokoa, $8 \mathrm{koa}$. Joan Ihartius eta Stefano Hirigoitiren laudoriozko bertsoak eta P. Argainarats-en akrostiko bal 
dakartza.

Londreseko British Museumean dago ezagutzen dugun ale bakarra.

Nc edizioa (katalogatu gabea)

"NOELAC I ETA BERCE | canta el'piritual | berriac. | le fus Chriftoren biciaren | mifterio principalen | gañean. | Eta fainduen ohoretan belta | buruetacotz. | Joannes ETCHEBERRI DoÍor | Teolegous: egniñac. (croix entre deux petits fleurons) | BAIONAN, I MAFFre Baitan bors I Cantognetan. 1697."

In-8 txikia erakoa, 240 orrialdetakoa da. Neumiak: 44 mm. x 96. Zeinadurak: A p. 1 , B p. 16, C p. 25, D p. 41 , E p. 49 , e.a.

Baimenak, onespen eta laudorioak besteetakoak dira. bilduman.

Newberry Librairyk, Chicagon, badu edizio honen ale bat. Luis Luziano Bonaparteren

Nd edizioa (Vinson, 15c)

"NOELAC I ETA BERCE I canta elpiritual | berriac. I lefus Chriftoren biciaren I mifterio principalen | gañean. | Eta lainduen ohoretan belta I buruetacotz. | Joannes ETCHEBERRI Dolor I Teolegoac: egniñac. | (croix entre deux petits fleurons) | BAIONAN, I MAFFrE Baitan bors I Cantognetan. I697."

In-8 txikia erakoa, 240 orrialdetakoa da. Neurriak: 44 mm. x 96. Zeinadurak: A p. I, B p. 16, C p. 25, D p. 41 , F. p. 49 , e.a.

Baimenak, onespen eta laudorioak besteetakoak dira, argitarapen guztietan bezalaxe.

Edizio honetako ale bat Koldo Mitxelena kulturguneko J. Urkixoren liburutegian dago.

Ne edizioa (Virson, 15d)

"NOELACI ETA BERCE ! canta elpiritual I berriac. | lefus Chriftoren biciaren I mifterio principalen ! gañean. | Eta fainduen ohoretan belta | buruetacotz. I Joannex ETCHEBERRI Dol̆or I Teolegoac egniñac. | (croix entre fleurons) I BAIONAN, I MAFFrE Baitan bors I Cantognetan. 1699."

In-8 txikia erakoa, 240 orrialdetakoa.

British Museumean diag() alurkitu dugun ale bakarra.

Nf edizioa (Vinson, 15e)

"NOEL AC I ETA BERCE I canta el piritual I berriac. I / efus Chriftoren biciaren I mifterio principalen | gafiean. I Eta fainduen ohoretan befta buruetacotz. I Ioannes ETCHEBERRI Dolor I Teolegnac egnifiac. | (croix simple) | BAIONAN,| MAFFRE Baitan, bors ! Cantognetan. 1699." 
Hau ere in-8 txikia erakoa, 240 orrialdetakoa. (241 orrialde zenbatu dira, baina hau 89. zenbakia falta eta 88.aren ondoren 90.a datorrelako da. Zenbaki honetatik aurrera, bada, erako orrialdeak zenbaki pareak dituzte, ezpareak itzulitakoak.) Zeinadurak: A p. 1, B p. 17. C p. 25, D p. 41, E p. 49, e.a. Neurriak: 41 mm. $5 \times 96,5$.

Berezitasun nabari bat dauka, 220. orrialdetik aurrera testuko letra desberdina da, askoz txikiagoa. Vinsonen ustez (1891-8: 70), argitarapen hau aurrekoaren faltsupena edo kontraegina da. Oker dago baina. Erakutsi dugu huts amankomunen azterketa eta stemma codicumaren bitartez Vinsonen $15 \mathrm{e}$ honek $15 \mathrm{cl}$ irakurtzen duela, ez $15 \mathrm{~d}$; beraz, uste hori ez da zuzena.

Ezagutzen dugun edizio honetako ale bakarra Donibane Lohitzunen dago, Maria Josefa Lanuzaren liburutegian.

Ng edizioa (Vinson, 15f)

"NOELAC I ETA BERCE ! canta elpiritual | berriac. ! Jefus Chriftoren biciaren I mifterio principalen I gañean. | Eta fainduen ohoretan belta | buruetacotz. | Joannes ETCHEBERRI Dollor I Teolegoac egniñciac. | (croix entre fleurons) I BAYONAN, I P. Fauveten, Imprimerian I Carmeffetaco aldean."

Hau ere in-8 txikia erakoa, 250 orrialdetakou da. Zeinadurak: A p. 1, B p. 17, C p. 25, e.a. Neurriak: $45 \mathrm{~mm} \times 95$. Betiko gaiak dakartza.

Edizio hau 1700-1730 bitartekoa da eta Koldo Mitxelena kulturgunean eta British Museumean edizio honen ale bana dute.

Argitarapen honen amaieran aurrekoetan agertzen ez diren bertso sortak ditugu: 241 . orrialdean verbum carnac, euskaraz; 245. ean claritates guçia, Ama Mariari eskeinitako abestia; 249. orrialdean Iesus Haurtcho larru, Iesusen zirkuntzisioari buruzko bertsoak.

Nh edizioa (Vinson, 15h)

"NOELA I ETA BERCE | canta Ipiritual berriac. | Jefus Chriforen hiciaren I mifferio principalen
gañean. | Eta fainduen ohoretan belta I buruetacotz. | Joannes ETCHEBERRI DoItor I Teolegoac
egnifiac. | (croix simple) | BAYONAN, I P. FAUVET, Imprimatcaillea | baithan. Carmelen aldean"

In-8 txikia erakoa, 240 orrialdetakoa. Zeinadurak: A p. 1, B p. 17, C p. 25, D p. 41, e.a.; neurriak: $45 \mathrm{~mm} \times 97$.

Argitarapen honetan, 211. orrialdetik aurrera, letraren neurria txikiagoa da. Argitarapen honek ere besteetan agertzen ez diren bertso sorta batzuk ditu amaieran. 232 . orrialdean, Stabat-en itzulpena; 235.ean, Gaudeac, Andra Mariari eskainiriko latinezko bertsoak; 236. orrialdean, Stabat latinez, eta 239. orrialdean erregeari eginiko otoitza latinez.

Newberry Librairyn dago edizio honen ale bat. 


\section{Ni edizioa (Vinson, $15 g$ )}

"NOELA I ETA I BERCE ! CANTA ! ESPIRTUUAL BERRIAC. | Jefus Chriftoren hiciaren mifferio I principalen I gañean. | Eta fainduen ohoretan befta I buruetacotz. | Joannes ETCHEBERRI Doĺor I Teolegoac egnifiac. | (3 gleurons, deux el un) I BAYONAN, I J. FAUVET, Imprimatcailiea I baithan, bortz-Cantoinetan."

Hau da era desberdineko bakarra, in-12koa, 204 orrialdetakoa. Zeinadurak: A p. 1. B p. 13, C p. 25, D p. 37, E p. 49, e.a. Neurriak: $58 \mathrm{~mm} \times 112$. Aurreko argitarapenean amaieran agertzen diren bertso sorta berri berberak agertzen dira honetan ere.

1731-1760 bitarteko edizio honen ale bat Koldo Mitxelena kulturgunean dago.

\section{Nj edizioa (Vinson, 15i)}

"NOELA I ETA BERCE I canta Ipiritual berriac. I Jesus Chriforen hiciaren mif- I terio principalen gañean I Eta fainduen ohoretan belta I buruetacotz. I JOANNES ETCHEBERRI, I Doctor Theolegoac egnifiac. I BAYONAN, I P. FAUvET, Imprimalçaillea I baithan, Carmefen aldean"

In-8 txikia erakoa. 230 orrialdetakoa. Zeinadurak: A p. 1. B p. 17, C p. 33, D p. 49, e.a. Neurriak: $51 \mathrm{~mm}$. 89 .

Honetan ere aurreko bi argitarapenetako bertso sorta berri berberak. 106. orrialdetik aurrera (bigarren ataletik aurrera, alegia) letraren neurria txikiagoa da.

Edizio honek, Vinsonek zioena zioela, 1760-1791 bitartekoa izan behar du, Paul Fauvetek, Paul zaharraren iloba, inprimatua bere inprenta berrian. ${ }^{94}$ Are, Vinsonek berak lagunduko digu uste hau sendotzen. Bere Essai...n (1891-8: 811-812) aipamen hau aurkituko dugu: «58.b (le n 58.b devenant 58.c) - AMA VIRGINAREN iragaitça, etc. Bayonne, P. FAUVET (vers 1760)». 16 lerтo geroago «Par sa disposition typographique, son format, les caractères employés, ce volume rappelle tout à fait la dernière édition des Noëls d'Etcheberri (n² 15.i, p. 72)». Berak argitzen digu, bada, «P. FAuVET (vers 1760)».

\section{Bibliografia}

\subsection{Lehen mailako ilurriak}

ETCHEBERRI, I., 1627, Manual devorion'zicoa, Bordelen, Gvillen Millanges Eitegueren Imprimatçaillearenean, M.DC. XXVII.

1645, Noelac eta berce canta espiritual berriac, Bordelen, Civillen Milanges Erreguesen Imprimatçaillea baithan.

i4 1760.ekoa Gure Herriaren arabera (1925: 708-710). 
1665, Eliçara erabiltceco liburua, Bordelen, 1. Mongiron Milangus Erreuturen Imprimatçaillea baithan.

-, 1666, Eliçara erabiliceco liburua, Bi:-arren aldian Imprimatua, Paven, Ioannes Desbaratz Erregueren Imprimatçailea Baithan.

- 1669, Manual devotionezcoa, Bordelen, 1. Mongiron Millanges Erregueren Imprimatçaillearenean, M.DC. LXIX.

- 1697a, Noelac eta berce canta espiritual berriac, Baionan, Maffre baitan, bosr Cantognetan.

_, 1697b, Noelac eta berce canta espiritual berriac, Baionan, Maffre baitan, bors Cantognetan.

___ , 1699a, Noelac eta berce canta espiritual berriac, Baionan, Mufffre baitan, bors Cantognetan.

-, 1699b, Noelac eta berce canta espiritual berriac, Baionan, Maffe baitan, bors Cantognetan.

Noelac ela herce canta espiritual berriac, Bayonan, P. Fauveten Imprimerian, Carmessetaco aldcian.

- Noelac eta berce cunta espiritual berriac, J. Fauvet, Imprimatcaillea baithan. bortz-Cantoiñetan.

-, Noelac eta berce canta espiritual berriac, Bayonan, P. Fauvet Imprimatcaillea baithan, Carmefen aldean.

- Noelac eta berce canta espiritual berriac. Bayonan, P. Fauvet Imprimatcaillea baithan, Carmelen aldean.

NOELAC-en parteak:

Euskal Herria, 1886, "Inozentzen amen dolorearen gañean noela", XIV, 12. or.

Gure Herria, 1925b, "Artzainak Bethleemen", V, 708-710. or.

Gure Herria, 1926b, "Noelac",Vl, 46-48. or.

Gure Herria, 1926a, "Trufaniaco Erregeak", VI, 32-40. or.

Gure Herria, 1926c, "Andrerena Mariaren elizan sartzearen ganean", VI, 125-128. or. 
Egan, 1955, "Eguberri-koplak", (núms. 5-6), 16. or.

Gure Herria, 1929b. "Joanes Etcheberri", 232. or.

\subsection{Lkerketak}

AKESOLO, L.,1970, Noelac eta berce cunta espiritual berriac. Sociedad Guipuzcoana de Ediciones, S. Sebastián.

ALTUNA, P., 1981, loannes Etxeberri Zibvrvkoa. Manval Devolionezcoa, Edizio kritikoa. Real Academia de la Lengua Vasca-Euskaltzaindia y Ediciones Mensajero, Bilbao.

ATUTXA, I., Joannes Etcheberri Ziburukoa: Obraren berrirakurketa bibliografia eta testukritika. Doktore tesia. Prestatzen.

BLECUA, A., 1988: Manucl de crifica textual, Editorial Castalia.

BONAPARTE, L. L., 1989, Eskuizkrihuak-Argilarapenak, Katalogoak. J, Euskaltzaindia, Azkue Biblioteka.

CULLINS, V., 1894, Attempl at a Calalogue of The Library of the late Prince Louis-Lucien Bonapar' hy' Victor Collins. Henry Sotheran \& Co.

DESGRAVES, L., 1971, Les livres imprimés a Bordeaux au XV/l siecle. Centre de Recherches d'Histoire et de Philologie, Genève, Librairie Droz. 11, rue Massot.

- 1972. "Les livres imprmés à Bayonne au XVII siècle". Bulletin de la Saciété Sciences, Lettres el Arls de Bayonne. 379-382. or.

1975, "Les livres imprimés à Bayonne au XVIIle siècle", Bulletin de la Socciélé Sciences, Lettres et Arts de Bayonne.161-178. or.

ETXENAGUSIA. K., 1981, Iparraldeko Euskal Idazleak, Labairu Ikastegia, Bilbo.

EUSKALTZAINDIA, 1992, Orotariko Euskal Hiztegia, VII Ere-Fa. Ediciones Mensajcro. S. A. Editorial Desclée DE Brouwer, S. A., Bilbao.

GOMEZ, R. \& LAKARRA, J. A. (arg.), 1992, Euskalaritzaren historiaz, I: XVI-XLX. mendeak, ASJUren Gehigariak 15, Donostia.

HARISTOY. P., 1895, St Jean de Luz el Ciboure. Souvenirs hystoriques et révolucionnaires avec quelque pages sur le Pays Basque. Par m. Nicolai avocat a la cour d'appel de Bordeaux. Pau. Imprimerie Viunancour. S. Dufau, Imprimeur 
HORDAGO PUBLIKAPENAK, 1978., Manual devotionezcoa edo ezperen oren oro escuetan errabiltçeco liburutchoa. Etxeberri Joannes, Editorial Lur, Donostia.

KEREJETA, M. J., 1988: «Oihenart S. Pouvreauren hiztegian», in Lakarra (arg.) 1988a, 35-73 or.

LABADIE, E., 1913, L'imprimerie bordelaise et les livres basques, Pau, G. LescherMoutoué, imprimeur, 11 rue de la Préfecture.

LAFITTE, P., 1931, Euskaldunen Lorategia, XWIgarren mendetik hunetako liburuetarik bildua. Lehen zatia (1645-1800), Baionan, Lasserre Liburutegian salgei, 20. Gambetta karrikan.

—_. 1967, "L'art poétique basque (Un inédit d'Arnaud d'Oyhénart)", Gure Herria.

LAKARRA J. A.: 1988a (arg.): Hiztegiak eta testuak, EHU-aren Argitalpen Zerbitzua. Bilbo.

-, 1988b: «Testukritikiz: 1. Stemmarantz», in Lakarra (are.), 1988a. 103-1.39 or.

LARRAMENDI, M., 1853, Diccionario Trilingüe Castellano. Bascuence y Latín, Nueva Edición publicada por don Pío de Zuazua, San Sebastián.

1984, El imposible vencido. ARTE de la lengua Bascongada, Editorial Amigos del libro.

LEIZARRA GA, I., 1990, lesus Christ gure Iaunaren Testamentu Berria, Kalendrera, ABC, Euskaltzaindia, Bilbo.

LHANDE, P.: 1926, Dictionnaire Basque-Français, Paris, Gabriel Beauchesne Editeur.

MICHEL, F., 1847, Proverbes basques d'Oihenart

ONAINDIA, S., 1954, Milla euskal-olerki eder, Karmeldar Idaztiak, Larrea-Amorebieta.

PEILLEN, T., 1983, Jusef Egiategi. Lehen liburia edo filosofo huskaldunaren ekheia. (1785). Euskaltzaindia. Bilbao.

PIERQUIN DE GEMBLouX, C. Ch., 1858a, Histoire Litteraire, philologhique et bibliographique des patois, Paris, Auguste Aubry, Libraire editeur (nouvelle édition).

__ 1858b, Bibliographie basque. Hommage a son altesse Le Prince Louis-Lucien Bomaparte.

RONCAGLIA, A., 1974, Principi e applicazioni di critica testuale, Universita' Degli Studi 
di Roma, Facoltà di Lettere e Filosofia, Bulzoni Editore, Roma.

SORARrAiN, G. de, 1984, Catálogo de obras euskaras, Caja de Ahorros Vizcaina, Colección bibliográfica, Serie Mayor, 3.

URKIZU, P., 1988, «Pierre d'Urteren hizzegia», in Lakarra (alw. 1988a, 77-99 or." "s

—, 1989, Pierre d'Urteren hizıcgia. EUTG-Mundaiz, Donostia. 2 lib.

, 1994, "Oihenarten Atsotitzak eta Poetika berrirakurriz». IKER 8. Euskaltzaindia. Bilbo. 295-328. or.

URQUIJO, J., 1909, "Las citas del Diccionario de Pouvreau", RIEV, III, 504-519. or. 1910b, "Notes d'Oihenart pour le Vocabulaire de Pouvreau", RIEV, IV.

VINSON, J., 1891, Essai de une bibliographie de la langue basque, Paris, 1891, Suplements et complements, Paris, 1898, Colección Bibliográfica, Serie Mayor l' y $1^{\text {"N }}$ (respectivamente), Caja Ahoros Vizcaína.

_ 1909, "Le Vocabulaire de Pouvreau", RIEV, IV.

— 1910b. "Notes d'Oihenart pour le Vocabulaire de Pouvreau", RIEV, V.

4 A trikulu berbera argitaralzen da lau urte geroago. Aipamena: "Pierre d'Urteren hiztegia", in Lisharra (arg.) 1992, 231-242. or.). 